\title{
Produção e utilização de indicadores educacionais: metodologia de cálculo de indicadores do fluxo escolar da educação básica*
}

Ruben Klein

Palavras-chave: fluxo escolar; taxas de transição; censo escolar; indicadores educacionais; educação básica.

\footnotetext{
* Este trabalho, que resultou de pesquisa parcialmente financiada pela Fundação Ford no projeto "Indicadores de Fluxo Escolar eEstudos sobre o Mecanismo da Repetência", foi apresentado preliminarmente (sem o subtítulo) no I Curso de Planejamento e Gestão da Educação Fundamental (MEC/SEF, SAF/ Enap e Unesco/IIPE, Brasília), em setembro de 1994, e, depois, numa segunda versão, no "Workshop sobre Repetência" (Unicef/IBE-Unesco, Genebra), em fevereiro de 1995. Agradeço ao professor Sergio Costa Ribeiro, grande incentivador para que eu trabalhasse neste assunto e com quem tive inúmeras discussões extremamente útei para o meu entendimento e para a elaboração deste trabalho, a Telma Suaiden Klein e Sonia Olesko, pelos comentários e pela ajuda na elaboração das suas duas primeiras versões, $\mathrm{e}$ finalmente, ao Inep/MEC, em especial a Carlos Moreno, Vanessa Néspoli e Carolina Pingret de Sousa, pela última revisão técnica desta versão atualizada, o que tornou possível a sua publicação.
}

\section{Resumo}

Traz a lume a correção do modelo de fluxo escolar para o sistema educacional brasileiro. Discute os conceitos e as formas de verificar a consistência do modelo e mostra a utilização equivocada de conceitos educacionais. Tem sido utilizado pelo Inep, desde seu lançamento, em 1994, e subsidiado o cálculo das taxas de transição de fluxo escolar para o Brasil e unidades da Federação.

\section{Análise de coorte}

Definição 1. Uma coorte é um grupo de pessoas que vivenciam conjuntamente uma série de eventos em um período de tempo. Denomina-se de tamanho de coorte o número de pessoas na coorte.

É necessário especificar a coorte quando mencionada. São apresentados a seguir dois exemplos de coortes.

Exemplo 1. Uma coorte escolar é definida como um grupo de alunos que entram, pela primeira vez, na primeira série de um determinado nível de ensino no mesmo ano escolar e que posteriormente vivenciam os eventos de promoção, repetência, evasão ou graduação, cada um à sua maneira.

Observação: Uma coorte escolar pode ter alunos (novos) de várias idades.

Exemplo 2. Uma coorte de 7 anos em 2001, ou seja, a coorte nascida em 1994, é definida como um conjunto das pessoas que têm 7 anos em 2001 ou que nasceram em 1994.

Observação: É necessário estabelecer uma regra para se falar que uma criança tem 7 anos em 2001. Exemplos de regras são:

a) a criança tem 7 anos em 2001, se completa 7 anos durante o ano de 2001, isto é, se completa 7 anos entre $1^{\circ}$ de janeiro de 2001 e 31 de dezembro de 2001. Ou seja, que nasceu durante o ano de 1994;

b)a criança tem 7 anos em 2001, se tem 7 anos completos em 30 de abril de 2001 (regra do Censo Escolar até 1995). Isto equivale à criança ter feito 7 anos entre $1^{\circ}$ de maio de 2000 e 30 de abril de 2001;

c)a criança tem 7 anos em 2001, se completou 7 anos entre $1^{\circ}$ de agosto de 2000 e 31 de julho de 2001, isto é, se tem 7 anos completos em 31 de julho de 2001. Esta é a coorte escolar de 7 anos em 2001.

Definição 2. Uma análise de coorte (escolar) é definida como o acompanhamento do fluxo de alunos novos que entram na $1^{\mathrm{a}}$ série do mesmo ano, até a saída do sistema escolar em consideração.

Para se fazer uma análise de coorte, seria preciso acompanhar todos os alunos novos que entram em um determinado ano. Isso é muito difícil. Uma alternativa seria acompanhar uma amostra. Mas isso também é difícil, pois exige um acompanhamento de todos os alunos na amostra até saírem do sistema escolar por graduação ou evasão. Só para o ensino fundamental, esse acompanhamento levaria provavelmente mais de 15 
anos, hoje em dia. Exige também acompanhar os alunos por suas transferências de escolas, etc. No fundo, exigiria ter um registro escolar individual confiável de cada aluno ao longo de toda a trajetória.

O que acontece com um aluno matriculado, por exemplo, na $3^{\mathrm{a}}$ série em 2001 ? Em 2002, esse aluno poderá estar na $4^{\mathrm{a}}$ série, caso em que "foi promovido", poderá estar ainda na $3^{\mathrm{a}}$ série, caso em que "está repetindo" e poderá estar fora do sistema escolar, caso em que "se evadiu". Se o aluno, que se evadiu, tiver sido aprovado na $3^{\mathrm{a}}$ série em 2001, ele é um evadido aprovado. Caso contrário, ele é um evadido nãoaprovado.

Um aluno matriculado, por exemplo, em 2001, no ano seguinte, pode ter sido promovido, pode estar repetindo ou pode ter se evadido.

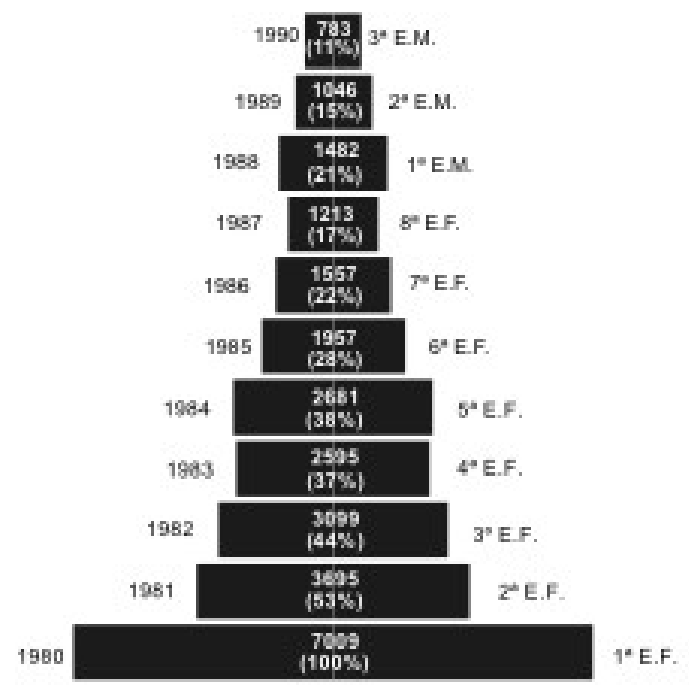

\section{Pirâmide educacional}

Uma tentativa errada de se fazer uma análise de coorte é o uso da pirâmide educacional, que foi muito utilizada anteriormente no País. Suas conclusões erradas produziram políticas educacionais equivocadas, causando um grande mal ao País. Por isto, é importante que a pirâmide educacional não seja mais utilizada para analisar uma coorte.

Definição 3. A pirâmide educacional (Figura 1) consiste numa figura, geralmente em forma de pirâmide, que relaciona as matrículas de séries consecutivas em anos consecutivos. A figura apresenta os porcentuais das matrículas das diversas séries em relação à matrícula da primeira série. Uma variante, às vezes utilizada, é usar as matrículas do mesmo ano.

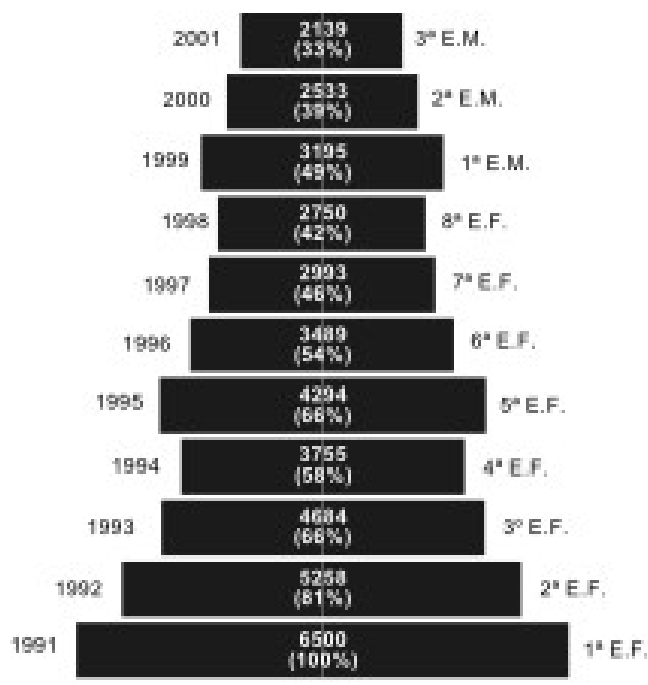

Figura 1 - Pirâmide educacional - 1980/1990 e 1991/2001, com a matrícula Inicial segundo Censos Educacionais, com correções de consistência, em unidade de milhar

Pode-se ver que houve uma evolução das matrículas do período de 1980 a 1989 em relação ao período de 1991 a 2001. No entanto as matrículas das $5^{\mathrm{a}}$ e $9^{\mathrm{a}}$ séries continuam maiores que as das $4^{\mathrm{a}}$ e $8^{\mathrm{a}}$ séries, o que contradiz o modelo, continuando-se com a impressão equivocada de que nem $60 \%$ dos alunos conseguem chegar à $4^{\mathrm{a}}$ série.

A pirâmide educacional não pode ser usada como uma análise de coorte escolar. Nesta interpretação incorreta, assume-se que todos os alunos são novos em todas as séries, isto é, todos os alunos na $2^{\mathrm{a}}$ série foram promovidos da $1^{\mathrm{a}}$ série, todos os alunos da $3^{\mathrm{a}}$ série, foram promovidos da $2^{\mathrm{a}}$ série, e assim sucessivamente. Se isso fosse verdade, poderse-ia, de fato, fazer uma análise de coorte e dizer, por exemplo (ver Figura 1), que $53 \%$ dos alunos novos matriculados na $1^{\mathrm{a}}$ série atingem a $2^{\mathrm{a}}$ série em 1981 e os $47 \%$ restantes evadem-se (saem do sistema escolar); e que $17 \%$ atingem a $8^{\mathrm{a}}$ série em 1987 e os 83\% restantes evadem-se antes de atingir essa série. 
Dizer que todos os alunos são novos é equivalente a dizer que não há repetência em todas as séries, mas somente evasão, o que não é verdade. Logo, segundo a definição 2, a pirâmide escolar não parte de uma coorte escolar, nem a acompanha, pois as matrículas de todas as séries, em todos os anos, são constituídas por alunos novos e repetentes.

Em outras palavras, o modelo da pirâmide educacional tem como hipótese básica que não há repetência, mas somente evasão. Como isso não é verdade, não se pode usar a pirâmide educacional.

\section{Simulação de uma coorte}

Uma maneira aproximada de se fazer a análise de uma coorte escolar é simular o fluxo dessa coorte, por exemplo, de mil alunos novos, que entram na $1^{\mathrm{a}}$ série, do ensino fundamental (Figura 2). Essa simulação geralmente é feita, supondo-se:

a) não há entrada de outros alunos novos em anos subseqüentes; b)um aluno que se evade não retorna mais ao sistema;

c)as taxas de repetência, promoção, evasão de aprovados e evasão de não-aprovados (ver definições 4 a 7 , adiante) para as diversas séries são constantes ao longo dos anos, não dependem da idade do aluno nem do fato de ele ser um aluno novo ou repetente.

Poder-se-ia, ainda, impor um limite ao número de anos que um aluno pode repetir uma determinada série. Isto não é feito, pois não se sabe da existência desse limite no ensino fundamental e médio no Brasil.

As taxas de repetência, promoção, evasão de aprovados e evasão de não-aprovados utilizadas são as estimadas para um determinado ano.

Se houver dados apropriados, poder-seá estimar as taxas por idade ou por aluno novo/repetente ou mesmo por idade e aluno novo/repetente, o que permitirá uma simulação mais próxima da realidade. Deve-se ter cuidado na especificação "aluno novo" e "aluno repetente”. Isso será tratado mais tarde.

Definição 4. A taxa de repetência na série $k$ no ano $t$ é a proporção dos alunos

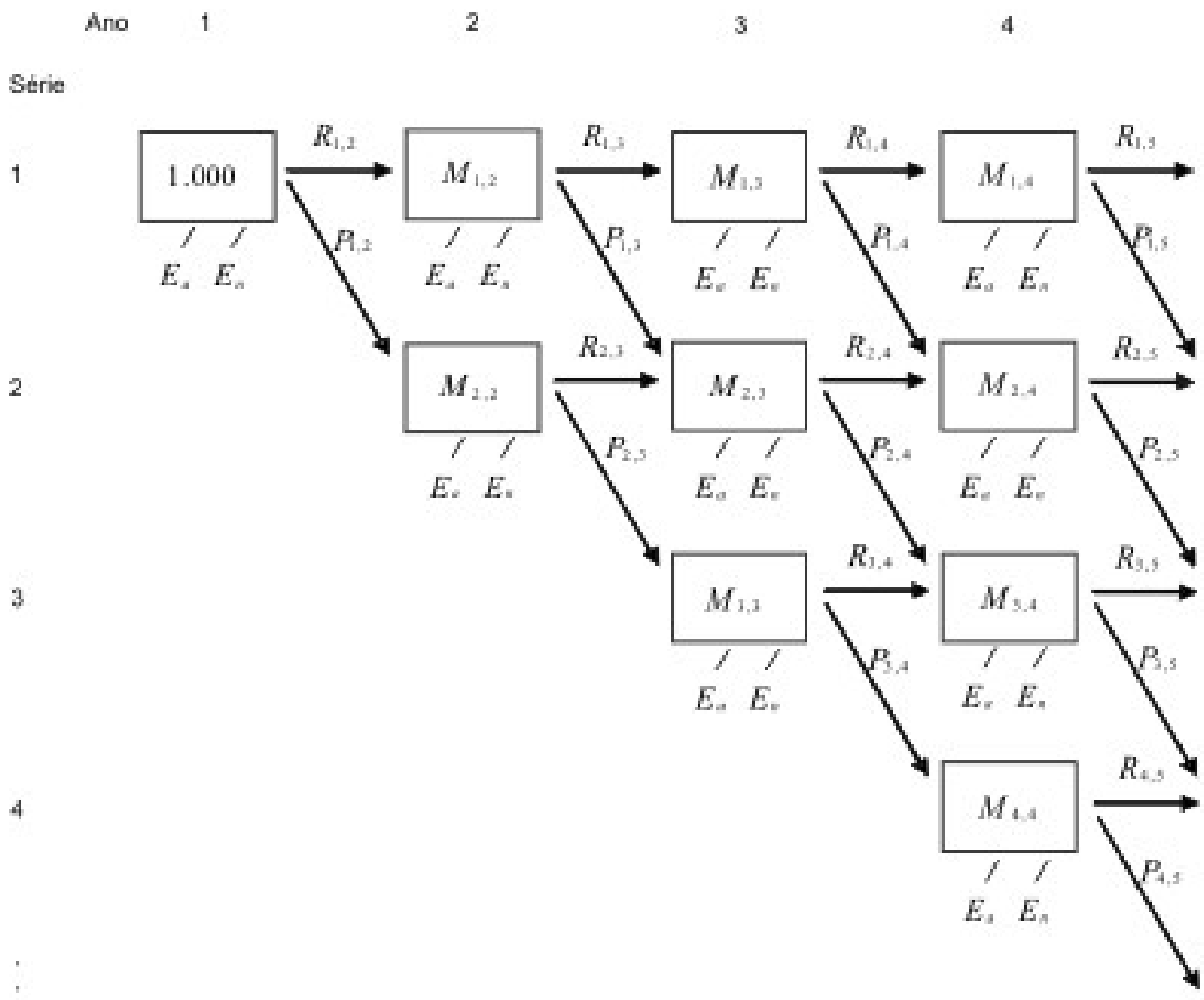

Figura 2 - Diagrama de fluxo escolar 
matriculados (matrícula total, ver definição 8) na série $k$ no ano $t$ que vão repetir a série $k$ no ano $t+1$.

Definição 5. A taxa de promoção da série $k$ no ano $t$ é a proporção de alunos matriculados (matrícula total, ver definição 8) na série $k$ no ano $t$ que vão se matricular na série $k+1$ no ano $t+1$.

Definição 6. A taxa de evasão de aprovados na série $k$ no ano $t$ é a proporção de alunos matriculados (matrícula total, ver definição 8) na série $k$ no ano $t$ que foram aprovados e não se matricularam no ano $t+1$.

Definição 7. A taxa de evasão de nãoaprovados na série $k$ no ano $t$ é a proporção de alunos matriculados (matrícula total, ver definição 8) na série $k$ no ano $t$ que não foram aprovados e não se matricularam no ano $t+1$.

Nas seções sobre o Modelo de Fluxo, será mostrado como estimar essas taxas.

\section{Indicadores derivados}

Na Tabela 1, a seguir, exibe-se um exemplo de simulação, para o Brasil, com as taxas estimadas para o ano de 2001. Podese calcular, a partir da simulação:

1)taxa de acesso à série $k=$ proporção de alunos que têm acesso à série $k$;

2)taxa de conclusão da série $k=$ proporção de alunos que concluem a série $k$;

3)taxa de graduação do ensino fundamental $=$ proporção de alunos que se graduam no ensino fundamental = proporção de alunos que concluem a oitava série;

4)número de matrículas utilizadas em cada série;

5)número total de matrículas utilizadas pela coorte;

6)número médio de anos freqüentados pelos alunos da coorte $=[$ (número de alunos que freqüentam somente 1 ano) $\times 1+$ (número de alunos que freqüentam somente 2 anos) $\times 2+$ (número de alunos que freqüentam somente 3 anos) x $3+\ldots$. / (número total de alunos) $=$ (número total de matrículas utilizadas pela coorte) / 1.000;

7)número médio de anos freqüentados pelos graduados $=[$ (número de alunos que se graduam em 8 anos) x $8+$ (número de alunos que se graduam em 9 anos) x $9+$ ...] / (número total de graduados);

8)número médio de anos freqüentados pelos evadidos aprovados $=[$ (número de alunos evadidos aprovados após 1 ano) x 1 + (número de alunos evadidos aprovados após 2 anos) x $2+\ldots$ ] / (número total de evadidos aprovados);

9)número médio de anos freqüentados pelos evadidos não-aprovados $=[$ (número de alunos evadidos não-aprovados após 1 ano) x $1+$ (número de alunos evadidos nãoaprovados após 2 anos) x $2+\ldots$. / (número total de evadidos não-aprovados);

10) número médio de anos freqüentados pelos evadidos $=$ [(número de alunos evadidos após 1 ano) x 1 + (número de alunos evadidos após 2 anos) x $2+$...] / (número total de evadidos) $=$ número médio de anos freqüentados pelos evadidos aprovados + número médio de anos freqüentados pelos evadidos não-aprovados;

11) número de anos de instrução por graduado $=$ (número total de matrículas utilizadas pela coorte) / (número de graduados).

\section{Modelo de fluxo para um sistema fechado}

Definição 8. Matrícula total na série $k$ no ano $t$ é a matrícula de todos os alunos admitidos durante o ano $t$ na série $k$.

Definição 9. Matrícula inicial é a matrícula verificada 30 dias após o início do ano letivo (definição do Censo Escolar até 1995; a partir de 1996, foi instituído o Dia Nacional do Censo Escolar - a última quarta-feira do mês de março, data de referência para a declaração da matrícula inicial).

Inicialmente, será considerado o modelo de fluxo para um sistema fechado, isto é, para um sistema em que um aluno admitido em uma escola após a data em que se verifica a matrícula inicial é um aluno transferido do próprio sistema, de modo que esse aluno já foi contado na matrícula inicial de todo o sistema.

Em um sistema fechado, a matrícula total é igual à matrícula inicial.

Definição 10. Matrícula final é a soma dos aprovados e reprovados.

Observação: Este conceito de matrícula final foi muito utilizado no Brasil e favoreceu uma definição errada de taxa de aprovação (ver observação após definição 13). Recomenda-se que o seu uso seja abandonado.

Definição 11. Um aluno afastado por abandono é qualquer aluno que não foi considerado aprovado ou reprovado. Logo, em um sistema fechado, o número deles é a 


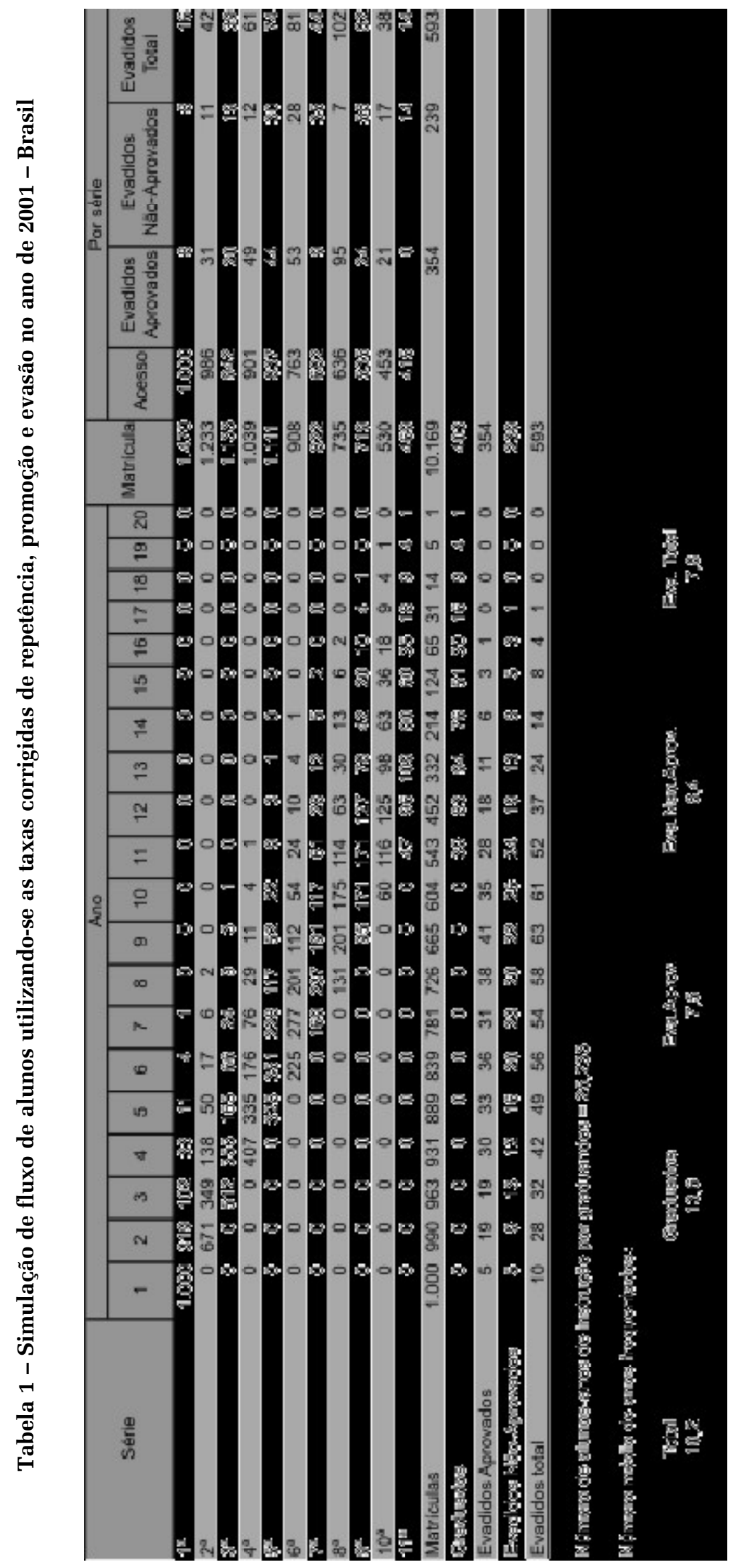


diferença entre a matrícula inicial e a matrícula final.

Um aluno matriculado na escola no fim do ano letivo será considerado aprovado, reprovado ou afastado por abandono (Figura 3). Portanto, um aluno não-aprovado é um aluno que foi considerado reprovado ou afastado por abandono.

No ano seguinte:

a) um aluno reprovado ou repete a série, sendo, portanto, um repetente reprovado, ou evade-se do sistema, sendo, portanto, um evadido reprovado;

b) um aluno afastado por abandono ou repete a série, sendo, portanto, um repetente por ter se afastado por abandono ou evade-se do sistema, sendo, portanto, um evadido por ter se afastado por abandono;

c) um aluno aprovado ou é promovido à série seguinte ou evade-se do sistema, sendo, portanto, um evadido aprovado, ou repete a série, sendo, portanto, um repetente aprovado.

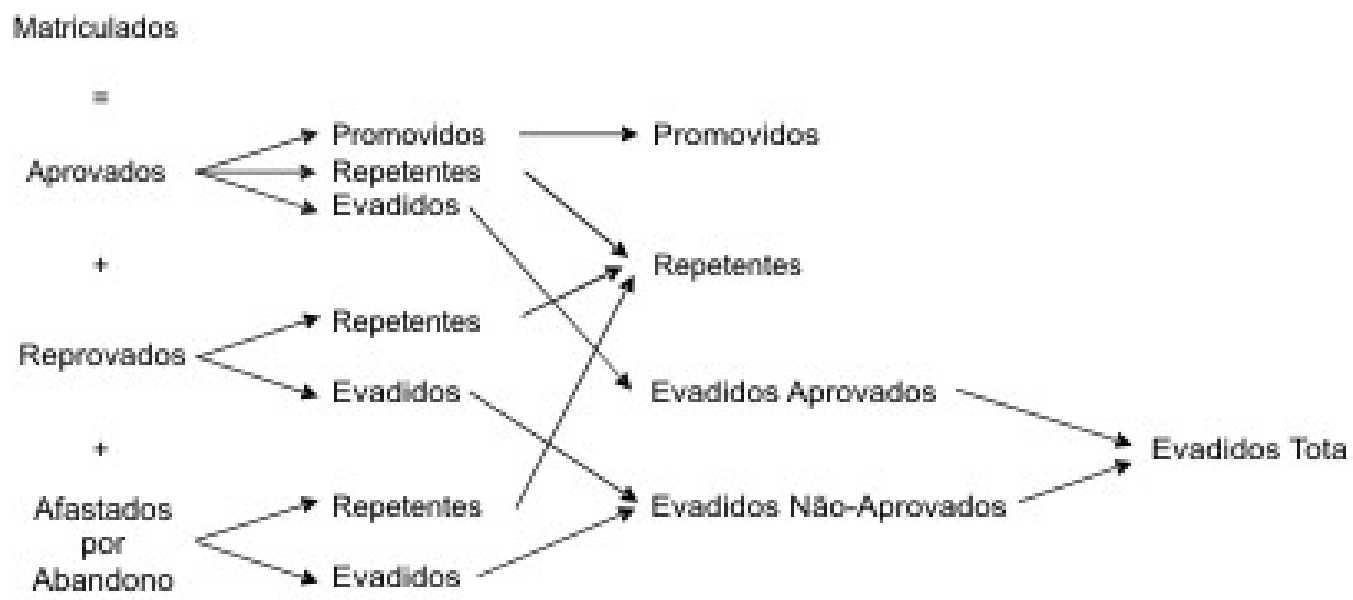

Figura 3 - Modelo de fluxo

Tem-se, portanto, três formas de repetência: por reprovação, por afastamento/por abandono e a repetência apesar da aprovação.

O sistema educacional e o Censo Escolar até 1993, inclusive, definiam como repetentes somente os alunos que tornavam a freqüentar a mesma série por terem sido reprovados por avaliação ou freqüência. Portanto, só consideravam uma parte dos repetentes.

Esse erro conceitual era a causa dos erros das estatísticas oficiais, quando se utiliza o Modelo de Fluxo a ser apresentado.

O questionário do Censo Escolar de 1994 já corrigiu esse erro conceitual e pergunta explicitamente o número de repetentes de cada uma das três formas.

Neste trabalho, é apresentado um modelo de ficha de matrícula escolar (Anexo 4) com as informações mínimas necessárias para que o questionário do Censo Escolar possa ser respondido sem problemas e que, também, permita fazer tabelas de fluxo da escola, da rede, do município, etc. Uma primeira versão dessa ficha foi aprovada pelo Conselho de Secretários Estaduais de Educação (Consed), em 1993.

A Figura 4, a seguir, apresenta um modelo de fluxo em forma de tabela. Na última coluna é apresentada a matrícula total (que, em um sistema fechado, coincide com a inicial) das diversas séries no ano $t$ (por exemplo, 2001). Na linha correspondente à série $k$, a matrícula dessa série é decomposta em quatro parcelas, a saber:

a) o número de alunos que estão repetindo esta série no ano $t+1$ (2002 no nosso exemplo), $R_{k, t+1}$;

b)o número de alunos que foram promovidos da série $k$ para a série $k+1$ no ano $t+1, P_{k, t+1}$;

c) o número de alunos que se evadiram após serem aprovados na série $k, E_{k, t a}$;

d) o número de alunos que se evadiram sem terem sido aprovados na série $k, E_{k, t, n}$. 


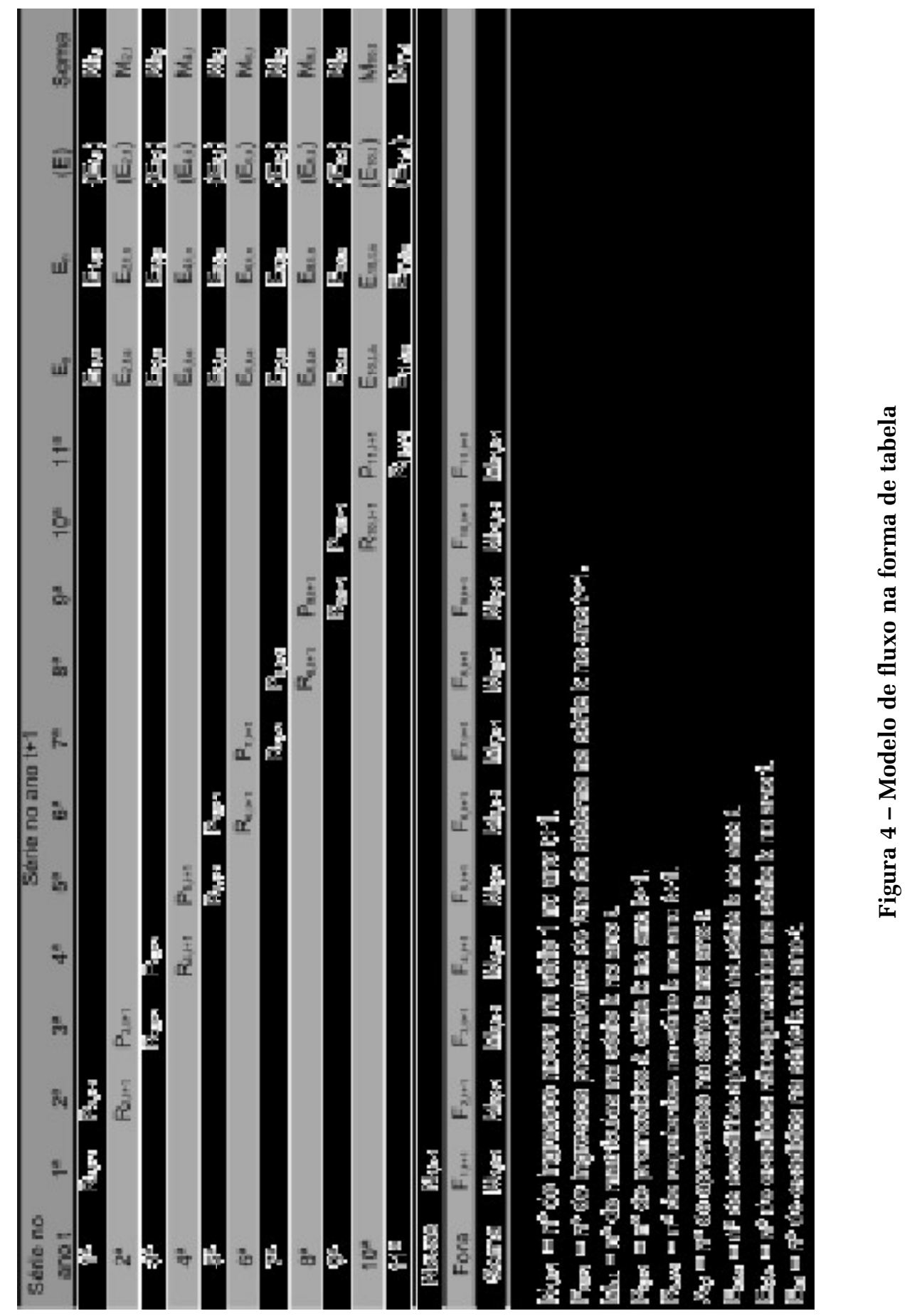


Em geral, as parcelas $c$ e $d$ são somadas, apresentando-se somente o número de alunos evadidos na série $k, E_{k, t}$.

$\mathrm{Na}$ coluna referente à série 1 do ano $t+1$ (2002, no exemplo), apresentam-se, de cima para baixo, o número de alunos repetentes na série 1 no ano $t+1$, o número de alunos novos (que estão entrando pela primeira vez no sistema considerado, no nosso caso, o ensino fundamental) na série 1 no ano $t+1$, o número de alunos que estão retornando à escola após, pelo menos, um ano de ausência na série 1 no ano $t+1$ e, finalmente, a matrícula inicial na série 1 no ano $t+1$.

Na coluna referente à série $k+1$ do ano $t+1$ (2002, no exemplo), apresentam-se, de cima para baixo, o número de alunos promovidos da série $k$ para a série $k+1$ no ano $t+1$, o número de alunos repetentes na série $k+1$ no ano $t+1$, o número de alunos provenientes de fora do sistema na série $k+1$ no ano $t+1$ e, finalmente, a matrícula inicial dessa série.

Esses alunos provenientes de fora do sistema podem ser alunos vindos, por exemplo, de outro país, de outra região, alunos que estão retornando ao sistema escolar depois de passar, pelo menos, o ano anterior fora do sistema (esses podem ser separados entre os que vão cursar a série pela primeira vez e os que a estão repetindo) alunos que vêm de outro sistema escolar, como do sistema supletivo para o sistema regular de ensino (ocorrência comum na primeira série do ensino médio).

Até recentemente não havia dados sobre esses alunos provenientes de fora do sistema. Supunha-se que o número fosse desprezível e ignorava-se. No entanto, na $1^{\mathrm{a}}$ série do ensino médio, esse número é considerável. A partir de 1994 o questionário do Censo Escolar passou a coletar essas informações. A ficha de matrícula proposta, anexa, registra estes dados.

Observação 1: Todos os termos na tabela de fluxo são não-negativos, isto é, são maiores que ou iguais a zero.

Observação 2: Considera-se a matrícula total para o ano $t$ e a matrícula inicial para o ano $t+1$. O motivo é que, dessa forma, pode-se analisar o fluxo dos alunos logo após a obtenção das matrículas iniciais no ano $t+1$. Supõe-se que a quase totalidade dos alunos admitidos após a época da matrícula inicial são alunos transferidos no meio do ano.

\section{Estimação dos termos da tabela de fluxo utilizando-se o Censo Escolar}

O Censo Escolar do ano $t+1$ nos fornece as matrículas iniciais de todos os alunos, de repetentes (e dos alunos provenientes de fora do sistema, a partir de 1994) para as diversas séries no ano $t+1$ e o número de aprovados e reprovados, por série, no ano $t$.

As Tabelas 3.2 a 3.7 do Anexo 3 apresentam, pela ordem, a matrícula inicial, a matrícula inicial de repetentes, a matrícula inicial de novos, o número de aprovados, o número de reprovados e o número de afastados por abandono, ao longo das décadas de 80 e 90, obtidos dos Censos Escolares. A matrícula de novos e o número de afastados por abandono foram obtidos por diferença, como explicado no texto. Os dados referentes ao Censo de 1983 foram imputados pelas médias dos anos anteriores e posteriores. A matrícula dos não-seriados (ciclo básico de alfabetização) em Minas Gerais, a partir de 1985, foi distribuída entre a $1^{\mathrm{a}}$ e a $2^{\mathrm{a}}$ série, de acordo com dados fornecidos pela Secretaria Estadual de Educação. Finalmente, os dados sobre não-seriados do Distrito Federal foram distribuídos segundo as mesmas proporções de Minas Gerais.

Os dados de 2000 em diante não incluem o $1^{\circ}$ ano do ensino fundamental de 9 anos como a classe de alfabetização (CA) e o $1^{\circ}$ ano do ciclo com duração de 3 anos destinados a crianças de 6 a 8 anos, que substitui as duas primeiras séries do ensino fundamental.

Até o ano de 1993, o Censo perguntava somente o número de repetentes reprovados, sub-registrando, portanto, o número de repetentes. Não coletava informações sobre alunos provenientes de fora do sistema. Os promovidos e os novos da primeira série eram calculados pela diferença entre a matrícula no ano $t+1$ e o número de repetentes no mesmo ano, sendo, portanto, superestimados. Conseqüentemente, todas as estatísticas baseadas nesses números estavam erradas.

A partir de 1994 o questionário do Censo Escolar passa a perguntar corretamente o número de repetentes reprovados, o de repetentes afastados por abandono, o de repetentes apesar de aprovados e o número 
de alunos provenientes de fora do sistema. Portanto, têm-se:

1)número de repetentes na série $k$ no ano $t+1=$ (número de repetentes reprovados na série $k$ no ano $t+1$ ) + (número de repetentes afastados por abandono na série $k$ no ano $t+1)+$ (número de repetentes apesar de aprovados na série $k$ no ano $t+1$ );

2)número de alunos novos na série 1 no ano $t+1=$ (matrícula inicial na série 1 no ano $t+1$ ) - (número de repetentes na série 1 no ano $t+1$ ) - (número de alunos que retornam ao sistema na série 1 no ano $t+1$ );

3)número de alunos promovidos da série $k$ para a série $k+1$ no ano $t+1=(m a-$ trícula inicial na série $k+1$ no ano $t+1)-$ (número de repetentes na série $k+1$ no ano $t+1$ ) - (número de alunos provenientes de fora do sistema na série $k+1$ no ano $t+1$ );

4)número de aprovados corrigido na série $k$ no ano $t=$ (número de aprovados na série $k$ no ano $t$ ) - (número de repetentes aprovados na série $k$ no ano $t+1$ );

5)número de evadidos aprovados na série $k$ no ano $t=$ (número de aprovados corrigido na série $k$ no ano $t$ ) - (número de promovidos da série $k$ para a série $k+1$ no ano $t+1$ )

6) número de evadidos não-aprovados na série $k$ no ano $t=$ (matrícula inicial na série $k$ no ano $t$ ) - (número de repetentes na série $k$ no ano $t+1$ ) - (número de promovidos da série $k$ para a série $k+1$ no ano $t+1$ ) - (número de evadidos aprovados na série $k$ no ano $t$ ) $=$ (número de não-aprovados) (número de repetentes não-aprovados);

7)número de evadidos reprovados na série $k$ no ano $t=$ (número de reprovados) - (número de repetentes reprovados);

8)número de evadidos afastados por abandono na série $k$ no ano $t=$ (número de afastados por abandono) - (número de repetentes afastados por abandono).

As taxas de repetência, promoção, evasão de aprovados e evasão de não-aprovados na série $k$ no ano $t$ são calculadas utilizando-se somente os termos na linha $k \mathrm{da}$ tabela de fluxo, da seguinte maneira:

1) taxa de repetência na série $k$ no ano $t$ $=$ (número de repetentes na série $k$ no ano $t+1$ ) / (matrícula total na série $k$ no ano $t$ );

2) taxa de promoção da série $k$ para a série $k+1$ no ano $t=$ (número de promovidos da série $k$ para a série $k+1$ no ano $t+1$ ) / (matrícula total na série $k$ no ano $t$ ); 3)taxa de evasão de aprovados na série $k$ no ano $t=$ (número de evadidos aprovados na série $k$ no ano $t$ ) / (matrícula total na série $k$ no ano $t$ );

4)taxa de evasão de não-aprovados na série $k$ no ano $t=$ (número de evadidos nãoaprovados na série $k$ no ano $t$ ) / (matrícula total na série $k$ no ano $t$ ).

O Censo Escolar do ano $t+1$ registra também o número de afastados por abandono e de transferidos, mas não registra o número de admitidos após a matrícula inicial (essa informação passou a ser coletada a partir de 1996). Em um sistema fechado, se tivéssemos esse número, poder-se-ia subtraí-lo do número de transferidos para ter o número de alunos que pediram transferência, mas não se rematricularam no sistema no mesmo ano, e que deveriam ser contados como afastados por abandono.

De fato, num sistema fechado, deverse-ia ter a igualdade:

Matrícula inicial $=$ matrícula final + afastados por abandono.

Mas, na verdade, encontra-se o seguinte:

Matrícula inicial > matrícula final + afastados por abandono.

O que está faltando são justamente os alunos classificados como transferidos em vez de afastados por abandono, por falta de informação. É por isto que se calcula o número de afastados por abandono como:

número de afastados por abandono $=$ matrícula inicial - matrícula final

\section{Modelo de fluxo para um sistema aberto}

\subsection{Caso de uma escola}

Para uma escola, a matrícula no ano $t$ a ser considerada (última coluna da tabela de fluxo - ver Figura 4) é a matrícula total na escola, isto é, a matrícula inicial mais os alunos admitidos durante o ano:

matrícula total na série $k$ no ano $t=$ (matrícula inicial na série $k$ no ano $t$ ) + (número de alunos admitidos na série $k$ durante $o$ ano $t$ ). 
Nesse caso, deve-se acrescentar uma coluna entre a coluna dos evadidos nãoaprovados e a da matrícula no ano $t$, para registrar as transferências durante o ano $t$. Não há como saber se esses alunos transferidos efetivamente se rematricularam em outra escola ou não, no mesmo ano.

Além das taxas acima descritas, calculadas em relação à matrícula, pode-se adicionar a taxa de transferência definida a seguir (ressalte-se que é possível que alguns registrados como transferidos são na verdade afastados por abandono):

taxa de transferência da série $k$ no ano $t=$ (número de alunos transferidos da série $k$ no ano $t$ ) / (matrícula na série $k$ no ano $t$ )

\subsection{Caso de um sistema aberto com duas ou mais escolas}

Exemplos de tais sistemas são a rede pública estadual, a rede pública municipal e a rede particular.

Nesse caso, tem-se que separar, entre os alunos admitidos após a data de verificação da matrícula inicial, os alunos provenientes de fora do sistema dos oriundos de escolas do próprio sistema.

A matrícula total é calculada da seguinte maneira:

matrícula total da série $k$ no ano $t=$ (matrícula inicial na série $k$ no ano $t$ ) + (número de alunos admitidos provenientes de fora do sistema na série $k$ durante o ano $t$ ).

O número efetivo de transferências do sistema passa a ser:

número de transferidos da série $k$ no ano $t=$ (soma do número de transferidos da série $k$ no ano $t$ de todas as escolas do sistema) - (número de alunos admitidos, após a matrícula inicial, na série $k$ durante o ano $t$, provenientes do próprio sistema)

Observação: No caso de um sistema aberto, é mais apropriado utilizar-se a expressão "saída do sistema” em vez de evasão, pois esta é caracterizada pela saída do aluno de todo o sistema escolar e não somente de uma parte, como no caso do sistema aberto. Por exemplo, o aluno sai da rede municipal, mas não se evade, pois entra na rede estadual.

\section{Análise de consistência do modelo de fluxo}

Como os Censos Escolares até 1993, inclusive, não dão nenhuma informação sobre alunos provenientes de outro sistema escolar ou que estão retornando à escola após pelo menos um ano de ausência, a análise é feita considerando-se esses termos como nulos (ou desprezíveis).

Todos os termos no modelo de fluxo são não-negativos. Logo, se na estimação de termos, como a dos evadidos aprovados ou nãoaprovados, aparecer algum negativo, há problema com a estimação dos outros termos.

O erro conceitual na definição de repetente, que considera somente os repetentes reprovados, leva a um sub-registro dos repetentes e, conseqüentemente, a uma superestimação dos promovidos ou novos nas diversas séries. Como conseqüência, tem-se um número de promovidos da série $k$ para a série $k+1$ usualmente maior que os aprovados na série $k$, dando um número negativo de evadidos aprovados - um óbvio absurdo. Na Tabela 3.8 (Anexo 3) estão apresentados os evadidos aprovados, calculados mediante o uso direto dos dados obtidos nos Censos Escolares. Pode-se observar ali os valores negativos obtidos.

A tabela de fluxo usual não considerava o evadido aprovado, e, portanto, o analista deixava de observar essa inconsistência.

$\mathrm{Na} 1^{\mathrm{a}}$ série tem-se o argumento da possibilidade demográfica. Esse argumento expressa o fato de que, em um sistema razoavelmente estável, o número de alunos novos na $1^{\mathrm{a}}$ série não pode superar o tamanho da coorte da idade modal, no caso, a coorte de 7 anos. A Tabela 3.9 do Anexo 3 nos dá a coorte de 7 anos ao longo da década, e a Tabela 3.10 apresenta a razão entre os novos não-corrigidos e a coorte de 7 anos. Os valores muito acima de 1 mostram que o número de alunos novos não-corrigido viola o argumento da possibilidade demográfica. Somente em um momento de intervenção no sistema pode haver uma entrada de alunos novos maior que a coorte modal. Depois o sistema volta à normalidade.

Esse argumento da possibilidade demográfica é conhecido na literatura. Podese citar: Teixeira de Freitas $(1947,1989)$, Schiefelbein (1975), Ribeiro e Fletcher (1987), Thonstad (1980, p. 34) e Cuadra (1989). Além dessas referências, pode-se citar Klein e Ribeiro (1991), que apresentam três novos argumentos. 


\section{Estimação das diversas taxas e intervalos com dados dos Censos Escolares}

Observação: Serão utilizados somente os dados sobre matrículas, aprovados e números de alunos provenientes de fora do sistema coletados nos Censos Escolares.

Definição 12. O número de não-aprovados na série $k$ no ano $t\left(N A P R_{k, t}\right)$ é definido como a soma do número de reprovados e de afastados por abandono na série $k$ no ano $t$. Em um sistema fechado,

$$
N A P R_{k, t}=M_{k, t}-A P R_{k, t}
$$

e o número de não-aprovados é baseado em números confiáveis.

Lembra-se aqui que o Censo Escolar até 1993, inclusive, não registra o número de alunos que retornam ao sistema após passarem pelo menos um ano fora da escola ou alunos que vêm de outro sistema, como o supletivo (esse número será denotado na série $k$ no ano $t$ por $F_{k, t}$ ). Supondo que esse número seja, em geral, pequeno, podendo ser desprezado, chama-se a atenção para a $1^{\mathrm{a}}$ série do ensino médio, onde ele não pode ser desprezado.

Se não houver repetência de aprovados, o número de não-aprovados é o número de repetentes máximo possível (RM), que corresponde ao retorno de todos os não-aprovados, o que equivale a uma evasão de nãoaprovados nula. Subtraindo da matrícula, levando em conta os alunos provenientes de fora do sistema, tem-se o número de promovidos mínimo possível (Pm). Isto é:

$$
\begin{gathered}
R M_{k, t+1}=N A P R_{k, t} \\
P m_{k, t+1}=\text { máximo }\left(M_{k, t+1}-F_{k, t+1}-R M_{k, t+1}, 0\right),
\end{gathered}
$$

pois $P m_{k, t+1}$ não pode ser negativo. Se $P m_{k, t+1}=0$, corrige-se o número máximo possível de repetentes para $R M C_{k, t+1}=M_{k, t+1}$ $F_{k, t+1}$

$\mathrm{Na} 1^{\mathrm{a}}$ série, em geral, o número de repetentes aprovados é considerável e não pode ser ignorado. Nas outras séries, esse número deve ser pequeno e pode-se ignorálo sem grande perda.

$\mathrm{Na} 1^{a}$ série, pode-se tomar o tamanho da coorte de 7 anos como referencial para o número de novos máximo possível.
Subtraindo da matrícula, tem-se o número de repetentes mínimo possível $(\mathrm{Rm})$ de referência. Isto é:

$$
R m_{1, t+1}=M_{1, t+1}-C O 7_{t+1}
$$

Observação: Para o País, para um Estado e talvez para um município, tem-se condições de estimar o tamanho da coorte pelo Censo Demográfico ou pelas Pnad's. Se o sistema escolar em consideração for a rede pública de um estado, tem-se que estimar a parcela da coorte ingressa na rede pública.

Para as demais séries, supondo que todos os aprovados corrigidos são promovidos dentro do sistema, isto é, matriculamse na série seguinte em uma escola do sistema (equivalente à evasão de aprovados ser nula), tem-se o número de promovidos máximo possível (PM). Subtraindo da matrícula, levando em conta os alunos provenientes de fora do sistema, tem-se o número de promovidos mínimo possível (Pm). Isto é:

$$
\begin{gathered}
P M_{k, t+1}=A P R C_{k, 1, t} \\
P m_{k, t+1}=\text { máximo }\left(M_{k, t+1}-F_{k, t+1}-R M_{k, t+1}, 0\right),
\end{gathered}
$$

pois $P m_{k, t+1}$ não pode ser negativo. Se $P m_{k, t+1}$ $=0$, corrige-se o número máximo possível de repetentes para

$$
R M C_{k, t+1}=M_{k, t+1}-F_{k, t+1} .
$$

Daqui em diante supor-se-á que $R M_{k, t+1}$ $R M C_{k, t+1}$ e $P M_{k, t+1}=P M C_{k, t+1}$. Caso isto não seja verdade, as diferenças $R M_{k, t+1}-R M C_{k, t+1}$ e $P M_{k, t+1}-P M C_{k, t+1}$ deverão ser acrescidas, respectivamente, aos evadidos não-aprovados na série $k$ e aos evadidos aprovados na série $k$.

Supondo-se que já se tenham os aprovados corrigidos na $1^{\mathrm{a}}$ série, têm-se, então, a partir da $2^{\mathrm{a}}$ série, os números de repetentes e promovidos máximo e mínimo possíveis. Portanto, se conhecem os intervalos onde os números de repetentes e promovidos têm que estar, e são, por conseguinte, médias ponderadas dos extremos dos intervalos. Tem-se então, para cada série $k$ e ano $t$, um número real $p_{k, t+1}$ tal que $0 \leq p_{k, t+1} \leq 1$ e:

$$
\begin{gathered}
R_{k, t+1}=p_{k, t+1} \times R M_{k, t+1}+\left(1-p_{k, t+1}\right) \times R m_{k, t+1} \\
R_{k, t+1}=R m_{k, t+1}+p_{k, t+1} \times\left(R M_{k, t+1}-R m_{k, t+1}\right) \\
R_{k, t+1}=R m_{k, t+1}+p_{k, t+1} \times D_{k, t+1}
\end{gathered}
$$




$$
\begin{gathered}
P_{k, t+1}=\left(1-p_{k, t+1}\right) \times P M_{k, t+1}=p_{k, t+1} \times P m_{k, t+1} \\
P_{k, t+1}=P M_{k, t+1}-p_{k, t+1} \times\left(P M_{k, t+1}-P m_{k, t+1}\right) \\
P_{k, t+1}=P M_{k, t+1}-p_{k, t+1} \times D_{k, t+1}
\end{gathered}
$$

Observa-se que:

1)os tamanhos dos intervalos são iguais, isto é, para $k=2, \ldots \ldots, 8, D_{k, t+1}=$ $P M_{k, t+1}-P m_{k, t+1}=R M_{k, t+1}-R m_{k, t+1}$. Estes valores são bem determinados, pois só dependem de quantidades conhecidas, como as matrículas, os aprovados e os números de alunos provenientes de fora.

2)número de evadidos não-aprovados na série $k$ no ano $t=$ (número de repetentes máximo possível na série $k$ no ano $t+1)$ - (número de repetentes na série $k$ no ano $t+1)=($ número de promovidos na série $k$ no ano $t+1)$ - (número de promovidos mínimo possível na série $k$ no ano $t+1$ ). Isto é, para $k=2, \ldots \ldots, 8$ :

$$
\begin{gathered}
E_{k, t, n}=R M_{k, t+1}-R_{k, t+1}=P_{k, t+1}-P m_{k, t+1} \\
\text { Logo, } \\
E_{k, t, n}=R M_{k, t+1}-\left(p_{k, t+1} \times R M_{k, t+1}+\left(1-p_{k, t+1}\right)\right. \\
\times R M_{k, t+1} \\
E_{k, t, n}=\left(1-p_{k, t+1}\right) \times\left(R M_{k, t+1}-R m_{k, t+1}\right) \\
E_{k, t, n}=\left(1-p_{k, t+1}\right) \times D_{k, t+1} \\
\mathrm{e} \\
0<E_{k, t, n}<D_{k, t+1} .
\end{gathered}
$$

3)número de evadidos aprovados na série $k$ no ano $t=$ (número de promovidos máximo possível na série $k+1$ no ano $t+1$ ) - (número de promovidos na série $k+1$ no ano $t+1)=($ número de repetentes na série $k+1$ no ano $t+1$ ) - (número de repetentes mínimo possível na série $k+1$ no ano $t+1$ ). Isto é, para $k=1, \ldots, 7$ :

$$
E_{k, a}=P M_{k+1, t+1}-P_{k+1, t+1}=R_{k+1, t+1}-R m_{k+1, t+1}
$$

Logo,

$$
\begin{gathered}
E_{k, t, a}=P M_{k+1, t+1}-\left[\left(1-p_{k+1, t+1}\right) \times P M_{k+1, t+1}\right. \\
\left.+p_{k+1, t+1} \times P m_{k+1, t+1}\right] \\
E_{k, t, a}=p_{k+1, t+1} \times\left(P M_{k+1, t+1}-P m_{k+1, t+1}\right) \\
E_{k, t, a}=p_{k+1, t+1} \times D_{k+1, t+1}
\end{gathered}
$$

$$
0<E_{k, t, a}<D_{k+1, t+1}
$$

Se $k=8$, tem-se que $E_{8, t, a}=0$ (considerase aqui somente o ensino fundamental; caso se considere conjuntamente o ensino médio, deve-se proceder como anteriormente).

4) $D_{k, t+1}=E_{k, t, n}+E_{k-1, t, a}$, isto é, a soma dos evadidos não-aprovados da série $k$ com os evadidos aprovados da série $k$ - 1 é igual à diferença entre o número máximo possível de repetentes (promovidos) e o número mínimo possível de repetentes (promovidos). Logo este é um valor bem determinado.

Somando-se ao longo de todas as séries $\left(E_{0, t, a}=0\right)$, verifica-se que o número total de evadidos é bem determinado.

Como se verá adiante, devido à existência dos repetentes aprovados, far-se-á hipóteses para a determinação de $E_{1, t, n}, E_{1, t, a}$ e $E_{2, t, a}$.

5)O número de evadidos total é igual à soma dos números de evadidos aprovados e não aprovados, isto é, para $k=2, \ldots, 7$ :

$$
\begin{gathered}
E_{k, t}=E_{k, t a}+E_{k, t, n}=p_{k+1, t+1} \times D_{k+1, t+1} \\
+\left(1-p_{k, t+1}\right) \times D_{k, t+1} \\
E_{k, t}=D_{k, t+1}+\left(p_{k+1, t+1} \times D_{k+1, t+1}-p_{k, t+1} \times D_{k, t+1}\right) \\
E_{k, t}<D_{k+1, t+1}<D_{k, t+1}
\end{gathered}
$$

Para $k=8$, tem-se:

$$
E_{8, t}=E_{8, t, n}-\left(1-p_{8, t+1}\right) \times D_{8, t+1}
$$

Se for possível estimar ou supor valores máximos e mínimos $p M_{k, t+1}$ e $p m_{k, t+1}$, respectivamente) para $\mathrm{pm}_{k, t+1}$, pode-se obter intervalos menores. Os intervalos para os números de repetentes, promovidos, evadidos aprovados e evadidos não-aprovados são obtidos de maneira análoga. O intervalo para números de evadidos é o seguinte:

$$
\begin{aligned}
p m_{k+1, t+1} \times D_{k+1, t+1}+\left(1-p M_{k, t+1}\right) \times D_{k, t+1} \\
<E_{k, t}<p M_{k+1, t+1} \times D_{k+1, t+1}+\left(1-p m_{k, t+1}\right) \\
\times D_{k, t+1}
\end{aligned}
$$

O comprimento do intervalo é:

$$
\begin{gathered}
\left(p M_{k+1, t+1}-p m_{k+1, t+1}\right) \times D_{k+1, t+1}+\left(p M_{k, t+1}\right. \\
\left.-p m_{k, t+1}\right) \times D_{k, t+1}
\end{gathered}
$$

A estimativa dos números de repetentes, promovidos e evadidos (equivalentemente das respectivas taxas) resume-se 
portanto à estimativa dos valores $p_{k, t+1}$ Na falta de mais informações tem-se que fazer suposições e/ou usar um julgamento subjetivo.

Algumas informações úteis são:

1) a proporção $\left(\right.$ pnapr $\left._{k, t+1}\right)$ de não-aprovados na série $k$ que retorna no ano $t+1$, ou seja:

$$
\begin{aligned}
\operatorname{pnapr}_{k, t+1}= & R_{k, t+1} / N A P R_{k, t} \\
\operatorname{pnapr}_{k, t+1}= & \left(p_{k, t+1} \times R M_{k, t+1}+\left(1-p_{k, t+1}\right)\right. \\
& \left.\times R m_{k, t+1}\right) / N A P R_{k, t}
\end{aligned}
$$

2) a proporção $\left(\right.$ pnapr $\left._{k, t+1}\right)$ de aprovados na série $k$ que retorna à série $k+1$ no ano $t+1$, ou seja:

$$
\begin{gathered}
\operatorname{papr}_{k, t+1}=P_{k+1, t+1} / A P R_{k} \\
\operatorname{papr}_{k, t+1}=\left(\left(1-p_{k+1, t+1}\right) \times P M_{k+1, t+1}+p_{k+1, t+1}\right. \\
\text { x } \left.P m_{k+1, t+1}\right) / A P R_{k, t}
\end{gathered}
$$

As taxas corrigidas utilizam $p=0,6$ a partir da série 3. Os intervalos construídos nos gráficos que compõem as Figuras $1.1 \mathrm{a}$ 1.6 do Anexo 1 utilizam $p=0,4$ e 0,8.

Nas Tabelas 3.13 a 3.16 (Anexo 3) mostra-se a proporção de retorno dos não-aprovados à mesma série no ano seguinte, para as seguintes situações: proporção mínima de retorno, proporção de retorno das taxas corrigidas e proporção de retorno dos extremos do intervalo.

Nas Tabelas 3.17 a 3.20 mostra-se a proporção de retorno dos aprovados à série seguinte no ano seguinte, para as mesmas situações anteriores.

Pode-se ver nas Tabelas 3.13 e 3.17 que a proporção mínima de retorno dos aprovados é maior que a dos não-aprovados e que, em geral, essas proporções são maiores em 2001 do que em 1981. Essas proporções são bastante altas, especialmente no caso dos aprovados.

O importante é que, como se tem os intervalos para os números, tem-se idéia da magnitude do erro.

Para obter as taxas relativas ao ano $t$, dividem-se os números pelas matrículas no ano $t$. Tem-se, então:

1) taxa de não-aprovação na série $k$ no ano $t=$ (número de não-aprovados (reprovados e afastados por abandono) na série $k$ no ano $t$ ) / (matrícula total na série $k$ no ano $t$ ):

$$
\operatorname{TXNAPR}_{k, t}=N A P R_{k, t} / M_{k, t} ;
$$

2) taxa de repetência máxima possível na série $k$ no ano $t=T X R M_{k, t}=T X N A P R_{k, t}$ (quando não há repetentes aprovados);

3) taxa de repetência mínima possível na série $k$ no ano $t=T X R m_{k, t}=R m_{k, t+1} / M_{k, t}$;

4) taxa de promoção máxima possível da série $k$ para a série $k+1$ no ano $t=T X P M_{k, t}$ $=P M_{k+1, t+1} / M_{k, t}$

Se $P M_{k+1, t+1}=A P R C_{k, t}$, então TXPM $M_{k, t}=$ $A P R C_{k, t} / M_{k, t}=$ taxa de aprovação corrigida na série $k$ no ano $t$;

5) taxa de promoção mínima possível da série $k$ para a série $k+1$ no ano $t=T X P M_{k, t}$ $=P M_{k+1, t+1} / M_{k, t}$;

6) taxa de repetência na série $k$ no ano $t$ $=\operatorname{TXR}_{k, t}=R_{k, t+1} / M_{k, t}=\operatorname{TXRm}_{k, t}+p_{k, t+1}$ x $D_{k, t+1} / M_{k, t}$;

7) taxa de promoção da série $k$ para a série $k+1$ no ano $t=T X P_{k, t}=P_{k+1, t+1} / M_{k, t}=$ $\operatorname{TXPM}_{k, t}-p_{k+1, t+1} \times D_{k+1, t+1} / M_{k, t}$;

8) taxa de evasão de aprovados na série $k$ no ano $t=T X E_{k, t, a}=E_{k, t, a} / M_{k, t}=p_{k+1, t+1}$ x $D_{k+1, t+1} / M_{k, t}$;

9) taxa de evasão de não-aprovados na série $k$ no ano $t=T X E_{k, t, n}=E_{k, t, n} / M_{k, t}=$ $\left(1-p_{k, t+1}\right) \times D_{k, t+1} / M_{k, t}$.

Os intervalos para as taxas são derivados como acima.

\section{Observa-se que:}

1) taxa de evasão de não-aprovados na série $k$ no ano $t=$ (taxa de repetência máxima na série $k$ no ano $t$ ) - (taxa de repetência na série $k$ no ano $t$ );

2) taxa de evasão de aprovados na série $k$ no ano $t=$ (taxa de promoção máxima da série $k$ para a série $k+1$ no ano $t$ ) - (taxa de promoção da série $k$ para a série $k+1$ no ano $t$ ).

Estimar a taxa de repetência na $1^{\mathrm{a}}$ série é mais difícil.

Se o número de não-aprovados na primeira série no ano $t$ for maior que o número de repetentes mínimos possível na primeira série no ano $t+1$, isto é, $N A P R_{1, t}>R m_{1, t+1}$, e se for razoável supor que o número de repetentes aprovados na primeira série é muito pequeno e pode ser desprezado (e, neste caso, o número de repetentes máximo 
possível seria igual ao número de não-aprovados, isto é, $R M_{1, t}=N A P R_{1, t}$ ), ter-se-iam os números de promovidos máximo e mínimo possíveis e poder-se-ia proceder como nas outras séries.

Chama-se a atenção para o fato de que a estimativa do tamanho da coorte de 7 anos $\left(C O 7_{t+1}\right)$ é muito importante, e os dados de Censos têm erros.

Um complicador é que intervenções no sistema podem afetar em muito o número de alunos novos na $1^{\mathrm{a}}$ série. Por exemplo, a introdução da classe de alfabetização em alguns Estados fez com que o número de novos ficasse bem abaixo da coorte de 7 anos no ano da introdução e com efeitos em anos posteriores. Um outro tipo de intervenção fazendo com que as crianças entrem mais cedo na escola poderia em um determinado ano fazer com que o número de novos fosse maior que a coorte de 7 anos. Pode-se controlar as análises prestando atenção nas taxas de evasão que não têm apresentado alterações bruscas no Brasil.

No Brasil como um todo, em quase todos os Estados e em quase todos os anos, tem ocorrido que: $N A P R_{1, t}<R m_{1, t+1}$.

Como conseqüência, tem que haver um número razoável de repetentes aprovados e que não pode ser ignorado.

Nesse caso, pode-se:

a) experimentar vários porcentuais da coorte de 7 anos como o número de alunos novos na $1^{\mathrm{a}}$ série e verificar a consistência das taxas de evasão de aprovados e nãoaprovados resultantes das diversas séries e, a partir daí, escolher uma que se ache razoável;

b)partir de hipóteses sobre as taxas de evasão de aprovados e não-aprovados na $1^{\mathrm{a}}$ série e de não-aprovados na $2^{\mathrm{a}}$ série e verificar se o número de alunos novos resultante é compatível com o argumento da possibilidade demográfica. Esse método tem mostrado bons resultados e sobre ele serão apresentados detalhes a seguir, derivando uma equação com o número de novos na $1^{\mathrm{a}}$ série em função das taxas de evasão.

Sejam $T X E_{1, t, n}, T X E_{1, t, a}$ e $T X E_{2, t, n}$, respectivamente, as taxas de evadidos não-aprovados na $1^{\mathrm{a}}$ série, de evadidos aprovados na $1^{\mathrm{a}}$ série e de evadidos não-aprovados na $2^{\mathrm{a}}$ série no ano $t$. Então, supondo que não há repetentes aprovados na $2^{\mathrm{a}}$ série:

$$
E_{2, t, n}=T X E_{2, t, n} \times M_{2, t}
$$

$$
\begin{gathered}
R_{2, t+1}=R N A P R_{2, t+1}=N A P R_{2, t}-E_{2, t, n} \\
=N A P R_{2, t}-\operatorname{TXE}_{2, t, n} \times M_{2, t} \\
P_{2, t+1}=M_{2, t+1}-F_{2, t+1}-R_{2, t+1}
\end{gathered}
$$

Observação: Tem-se que $P_{2, t+1}<A P R_{1, t}$. Caso contrário, terá que reduzir $T X E_{2, t, n}$.

$$
\begin{aligned}
& E_{1, t, a}=T X E_{1, t, a} \times M_{1, t} \\
& A P R_{1, t}=P_{2, t+1}+E_{1, t, a}
\end{aligned}
$$$$
\text { (aprovados corrigidos) }
$$

$$
R A P R_{1, t+1}=A P R_{1, t}-A P R C_{1, t}
$$

(repetentes aprovados)

$$
\begin{gathered}
R A P R_{1, t+1}=A P R_{1, t}-M_{2, t+1}+F_{2, t+1}+N A P R_{2, t} \\
-T X E_{2, t, n} \times M_{2, t}-T X E_{1, t, a} \times M_{1, t}
\end{gathered}
$$

Observação: Se $R A P R_{1, t+1}<0$, tem-se que reduzir o valor de $T X E_{1, t, a}$ e/ou $T X E_{2, t, n}$.

$$
\begin{gathered}
E_{1, t, n}=\operatorname{TXE}_{1, t, n} \times M_{1, t} \\
R N A P R_{1, t+1}=\operatorname{NAPR}_{1, t}-E_{1, t, n}=N A P R_{1, t} \\
-T_{1, t, n} \times M_{1, t} \\
R_{1, t+1}=R N A P R_{1, t+1}+R A P R_{1, t+1} \\
N_{1, t+1}=M_{1, t+1}-F_{1, t+1} R_{1, t+1}=M_{1, t+1}-F_{1, t+1} \\
-A P R_{1, t}+M_{2, t+1}-F_{2, t+1}-N A P R_{2, t}+T X E_{2, t, n} \\
\times M_{2, t}+T_{1 X E_{1, t a}} \times M_{1, t}-N A P R_{1, t}+T X E_{1, t, n} \times M_{1, t}
\end{gathered}
$$

Ou seja:

$$
\begin{gathered}
N_{1, t+1}=M_{1, t+1}-M_{1, t}+M_{2, t+1}-F_{1, t+1}-F_{2, t+1} \\
-N A P R_{2, t}+T_{2 X E_{2, t, n} \times M_{2, t}+T X E_{1, t, a} \times M_{1, t}} \\
+T_{1 X E_{1, t, n} \times M_{1, t}}
\end{gathered}
$$

Logo $N_{1, t+1}$ é função crescente de $T X E_{2, t, n}$, $T X E_{1, t, a}$ e $T X E_{1, t, n}$.

Observação: $T X E_{2, t, n}=T X E_{1, t, a}=T X E_{1, t, n}$ $=0$ dá o valor mínimo de $N_{1, t+1}$, o número de novos na $1^{\mathrm{a}}$ série no ano $t+1$. Se achar que esse valor ainda é muito alto perante a possibilidade demográfica e que não houve intervenção no sistema escolar que o justifique, então tem que haver repetente aprovado na $2^{\mathrm{a}}$ série no ano $t+1, R A P R_{2, t+1}$, ou o número de alunos de fora do sistema na $1^{\mathrm{a}}$ série e/ou na $2^{\mathrm{a}}$ série tem que ser maior. Em geral, tem-se suposto que $F_{1, t+1}=0$. É provável que a proporção de alunos de fora do 
sistema na $1^{\mathrm{a}}$ série em relação à matrícula seja da ordem de 0,02 (2\%).

Tem-se então que estimar $R A P R_{2, t+1}$, corrigir os aprovados na $2^{\mathrm{a}}$ série no ano $t \mathrm{e}$ os repetentes na $2^{\mathrm{a}}$ série no ano $t+1, R_{2, t+1}$, e refazer a derivação. Chega-se a:

$$
\begin{gathered}
N_{1, t+1}=M_{1, t+1}-M_{1, t}+M_{2, t+1}-F_{1, t+1}-F_{2, t+1} \\
-N A P R_{2, t}+\operatorname{TXE}_{2, t, n} \times M_{2, t}+\operatorname{TXE}_{1, t, a} \times M_{1, t} \\
+\operatorname{TXE}_{1, t, n} \times M_{1, t}-R A P R_{2, t+1}
\end{gathered}
$$

Observa-se que, de fato, $N_{1, t+1}$ diminui com a introdução de $R A P R_{2, t+1}$, como desejado.

Uma vez estimado o número de repetentes e o número de promovidos, calculase o número de evadidos aprovados e o de não-aprovados. Logo, pode-se construir a tabela de fluxo e obter todas as taxas.

Chama-se a atenção para o fato de que está sendo utilizado o procedimento acima para a obtenção do número de alunos novos na $1^{\mathrm{a}}$ série no Brasil, onde está praticamente universalizado o acesso. Pode ser que, em lugares onde tal não ocorra, sejam necessários alguns ajustes.

As Tabelas 3.21 a 3.31 (Anexo 3) fornecem as taxas referentes a repetência, promoção e evasão corrigidas e não-corrigidas.

As Figuras 1.1 e 1.2 (Anexo 1) apresentam, para o Brasil, um registro para cada série, com as taxas de não-aprovação, as taxas de repetência corrigida, as taxas de repetência mínima, as taxas de reprovação, as taxas de afastados por abandono e as taxas de repetência informadas (calculadas diretamente dos dados dos Censos Escolares) de 1981 a 2001. As Figuras 1.3 e 1.4 apresentam as taxas de promoção e evasão.

\section{Taxa de aprovação e outras taxas provenientes do modelo de fluxo}

A seguir, será apresentada a definição de taxa de aprovação consistente com o modelo de fluxo.

Definição 13. A taxa de aprovação é definida como a razão entre o número de aprovados e a matrícula total, isto é:

taxa de aprovação na série $k$ no ano $t$ $=$ (número de aprovados na série $k$ no ano $t$ ) / (matrícula total na série $k$ no ano $t$ ).

Observação: O sistema educacional costuma utilizar uma definição equivocada da taxa de aprovação, utilizando a matrícula final no lugar da matrícula total.

A conseqüência do uso dessa definição equivocada da taxa de aprovação é inflar a taxa de aprovação. Dessa maneira, era interessante para as escolas que houvesse o abandono. Provavelmente, só vai baixar muito o abandono quando o sistema escolar e as escolas perceberem que a taxa de aprovação não é por ele afetada.

Outras taxas que se pode obter do modelo de fluxo são as proporções de repetentes, de novos ou promovidos e de alunos provenientes de fora do sistema em relação à matrícula inicial no ano $t+1$. Para isso, basta considerar as relações obtidas pelas colunas da tabela de fluxo.

Os dados obtidos a partir da ficha de matrícula permitem obter todas as taxas citadas acima por idade, o que nos daria muita informação a respeito da composição etária das diversas séries.

Por exemplo:

taxa de alunos com idade $i$ na série $k$ no ano $t=$ (matrícula inicial dos alunos com idade $i$ na série $k$ no ano $t$ ) / (matrícula inicial na série $k$ no ano $t$ ).

Pode-se ter a distribuição dos alunos novos na série $k$, por idade:

taxa de ingresso novo com idade $i$ na série $k$ no ano $t=$ (matrícula inicial de alunos novos (ou promovidos) com idade $i$ na série $k$ no ano $t$ ) / (matrícula inicial de novos na série $k$ no ano $t$ )

Observação: Para o uso dessa taxa, é fundamental que os alunos novos sejam classificados corretamente. Esse problema está relacionado ao erro conceitual na definição de repetente. Um aluno novo na série $k$ no ano $t$ é um aluno que ingressa pela primeira vez na série. Se ele é considerado um afastado por abandono na série em anos anteriores ou é um repetente aprovado ou está retornando a uma série em que já se matriculou anteriormente, não é, então, um aluno novo.

\section{Outras taxas utilizadas}

É utilizada a matrícula inicial nas definições abaixo para que as taxas possam ser calculadas logo após a data dessa matrícula, isto é, no início do ano. 
taxa de admissão bruta $=$ (número de alunos novos na primeira série) / (tamanho da coorte de 7 anos)

Observação: Pelo argumento da possibilidade demográfica, em um sistema razoavelmente estável, essa taxa deve ser menor que um. Na seção 9, foram experimentados vários valores possíveis dessa taxa como um dos métodos de estimar a taxa de repetência na $1^{\mathrm{a}}$ série.

taxa de admissão com idade $i=$ (número de alunos novos na $1^{\mathrm{a}}$ série com idade i) / (tamanho da coorte de idade $i$ )

Observação: Essa taxa depende da maneira de discretizar a idade. Ver definição de coorte de idade na seção 1.

A seguir serão apresentadas definições, largamente utilizadas pelo sistema escolar, que envolvem a freqüência na escola, com comentários:

taxa de matrícula bruta em um determinado ciclo $=$ (matrícula inicial no ciclo $)$ / (tamanho da população escolar das idades consideradas corretas).

Por exemplo:

taxa de matrícula bruta no ensino fundamental $=$ (matrícula inicial no ensino fundamental) / (tamanho da população de 7 a 14 anos);

taxa de matrícula bruta no ensino médio = (matrícula inicial no ensino médio $)$ / (tamanho da população de 15 a 17 anos).

Observação: Está sendo considerado aqui um ensino médio de somente três séries.

taxa de matrícula líquida em um determinado ciclo $=$ (matrícula inicial dos alunos de idade considerada correta no ciclo) / (tamanho da população escolar das idades consideradas corretas).

Por exemplo:

taxa de matrícula líquida no ensino fundamental $=$ (matrícula inicial dos alunos de 7 a 14 anos no ensino fundamental) / (tamanho da população de 7 a 14 anos);

taxa de matrícula líquida no ensino médio $=$ (matrícula inicial dos alunos de 15 a 17 anos no ensino médio) / (tamanho da população de 15 a 17 anos).
Observação: Geralmente a taxa de matrícula líquida no ensino fundamental é chamada de taxa de escolarização da população de 7 a 14 anos.

Essas taxas apresentam o defeito de serem estáticas: são um retrato no ano $t$. Não levam em conta alunos que ainda vão entrar na escola ou que dela já saíram. No ensino fundamental ainda há muitos alunos que só entram aos 8 anos ou mais, e, no ensino médio, poucos entram na idade correta dos 15 anos.

Usualmente, a taxa de escolarização da população de 7 a 14 anos é interpretada equivocadamente. Por exemplo, a taxa de escolarização da população de 7 a 14 anos no ensino fundamental, no Brasil, em 2000, é de 94,3\% (dados do Inep). É comum a interpretação de que 94,3\% têm acesso à escola ou, equivalentemente, de que $5,7 \%$ não têm acesso ao ensino fundamental. Esta interpretação está equivocada, pois a taxa de escolarização só nos fornece o porcentual da população de 7 a 14 anos freqüentando a escola naquele ano. O acesso de uma coorte de idade só pode ser medido por dados demográficos, e a taxa de acesso ao ensino fundamental é dada pela taxa de participação na $1^{\mathrm{a}}$ série, que está em 98,6\%, em 2001 (ver seção 12 e Tabelas 3.32 e 3.33 do Anexo 3).

As taxas por idade, a seguir, dão mais informação. No entanto, taxas de participação de uma coorte que nasceu em um determinado ano só podem ser obtidas com os dados demográficos e não com os dados dos Censos Escolares.

taxa de matrícula com idade $i=$ (matrícula inicial dos alunos com idade $i$ ) / (tamanho da coorte de idade $i$ ).

Essa taxa pode ser decomposta em:

taxa de matrícula com idade $i$ na série $k$ no ano $t=$ (matrícula inicial dos alunos com idade $i$ na série $k$ no ano $t$ ) / (tamanho da coorte de idade $i$ ).

Pode-se, assim, ter a porcentagem de alunos da coorte de idade $i$ que sejam novos na série $k$.

taxa de matrícula de ingresso novo com idade $i$ na série $k$ no ano $t=$ (número de alunos novos com idade $i$ na série $k$ no ano t) / (tamanho da coorte de idade $i$ ). 


\section{Indicadores obtidos através dos dados das Pnad's}

A Pesquisa Nacional por Amostra de Domicílio (Pnad) do IBGE é realizada anualmente, exceto nos anos do Censo Demográfico, de setembro a novembro.

Pode-se utilizar os seguintes itens do questionário de mão-de-obra da Pnad, cuja informação é obtida para todo residente no domicílio amostrado:

a) idade;

b) se o indivíduo freqüenta a escola, qual o grau e série;

c) se o indivíduo freqüenta a escola, qual foi a última série e grau concluídos com êxito; aluno.

d) características socioeconômicas do

O item $d$ permite obter indicadores educacionais por características socioeconômicas.

A partir de 1992, existem perguntas para separar corretamente o sistema regular de ensino do ensino supletivo.

A partir dos dados da Pnad, pode-se estimar a matrícula em cada série e grau, a proporção dos alunos com idade $i$ matriculados em todas as séries e em cada uma separadamente, a proporção dos alunos de idade $i$ que já concluíram a série $k$ e uma cota inferior para a proporção dos alunos que já ingressaram (tiveram acesso) na série $k$.

Definição 14. Taxa de participação na série $k$ de uma coorte nascida no ano $t$ é o porcentual da coorte que tem acesso à série $k$. Esse acesso à série $k$ geralmente se dá em vários anos. A situação ideal é que toda a coorte tenha tido acesso à série $k$ na idade ideal.
Definição 15. Taxa de conclusão da série $k$ de uma coorte nascida no ano $t$ é o porcentual da coorte que conclui com êxito a (é aprovada na) série $k$. Essa aprovação na série $k$ geralmente se dá em vários anos. A situação ideal é que toda a coorte tenha concluído com êxito a série $k$ na idade ideal.

A taxa de participação na série $k$ de uma coorte nascida no ano $t$ é estimada pela proporção de alunos nascidos no ano $t$ que já ingressaram na série $k$, quando não ocorre mais ingresso nessa série. Isso ocorre para as coortes mais antigas (ver Gráfico 2.1, Anexo 2). O máximo da curva dos já ingressos determina a idade e a coorte para a qual a taxa de participação é máxima. Esta é denominada de taxa de participação atual. Pode-se ver no Gráfico 2.1 que essa taxa vem crescendo ao longo dos anos. A Tabela 3.32 (Anexo 3) mostra as taxas de participação obtidas das Pnad's de 1981 a 2001.

De maneira análoga, estima-se a taxa de conclusão da série $k$ de uma coorte nascida no ano $t$. Valem comentários análogos. A Tabela 3.33 (Anexo 3) mostra-nos também as taxas de conclusão obtidas das Pnad's de 1981 a 2001. A taxa de conclusão obtida em uma Pnad refere-se ao ano anterior ao da pesquisa.

Os doutores Philip Fletcher e Sergio Costa Ribeiro desenvolveram o Profluxo (ver Fletcher e Ribeiro, 1988; Klein, 1991), que é o Modelo de Fluxo onde todos os termos são expressos em proporção de coorte. Sob hipótese de estabilidade e utilizando somente uma Pnad, eles usam a aproximação de que as matrículas, em proporção de coorte, em dois anos consecutivos, são as mesmas. Os novos, em proporção de coorte, são estimados pela taxa de participação atual, e os repetentes, por diferença. Os evadidos aprovados e não-aprovados são estimados em proporção de coorte da maneira usual.

\section{Referências bibliográficas}

CUADRA, E. Indicators of student flow rates. Cambridge, USA: Harvard Graduate School of Education, 1989. (Bridges Research Report Series, n. 6).

FLETCHER, P. R.; RIBEIRO, S. Costa. Projeto fluxo dos alunos de primeiro grau - Profluxo. [S.l.], 1988. Versão Preliminar. Mimeografado. 
FREITAS, M. A. Teixeira de. A escolaridade média no ensino primário brasileiro. Revista Brasileira de Estatística, v. 8, n. 30/31, p. 295-474, 1947.

. A escolaridade média no ensino primário brasileiro. Revista Brasileira de Estatística, v. 50, n. 194, p. 73-159, 1989. Com comentário de S. Costa Ribeiro.

KLEIN, R. Descrição da Metodologia do Profluxo: relatório 1. 1991. (United Nations Project Symbol: BRA/90/026 - M. O. D. no. 91-006).

KLEIN, R.; RIBEIRO, S. C. O Censo Escolar e o Modelo de Fluxo: o problema da repetência. [S.l.]: Laboratório Nacional de Computação Científica, 1991. (Relatório de Pesquisa e Desenvolvimento, n. 24/91).

RIBEIRO, S. C.; FLETCHER, P. R. O Ensino de $1^{\circ}$ grau no Brasil de hoje. Em Aberto, Brasília, v. 6, n. 33, p. 1, jan./mar. 1987.

SCHIEFELBEIN, E. Repeating: an overlooked problem. Comparative Education Review, v. 19, n. 3, p. 468-487, 1975.

THONSTAD, T. Analysing and projecting school enrolment in developing countries: a manual of methodology. Paris: Unesco, 1980. (Statistical Reports and Studies, n. 24).

Ruben Klein, pesquisador aposentado do Laboratório Nacional de Computação Científica (LNCC/MCT), é consultor da Fundação Cesgranrio.

\section{Abstract}

This work points out the correction of the model of school flow for the Brazilian educational system, it discusses concepts and forms of verifying the consistence of the model and it shows the mistaken use of educational concepts. The model has been used by Inep, since its release in 1994, and subsidized the calculation of the rates of school flow transition for Brazil and units of the Federation.

Keywords: school flow; transition rates: promotion, retention and evasion, cohort and school census. 


\section{Anexo 1}
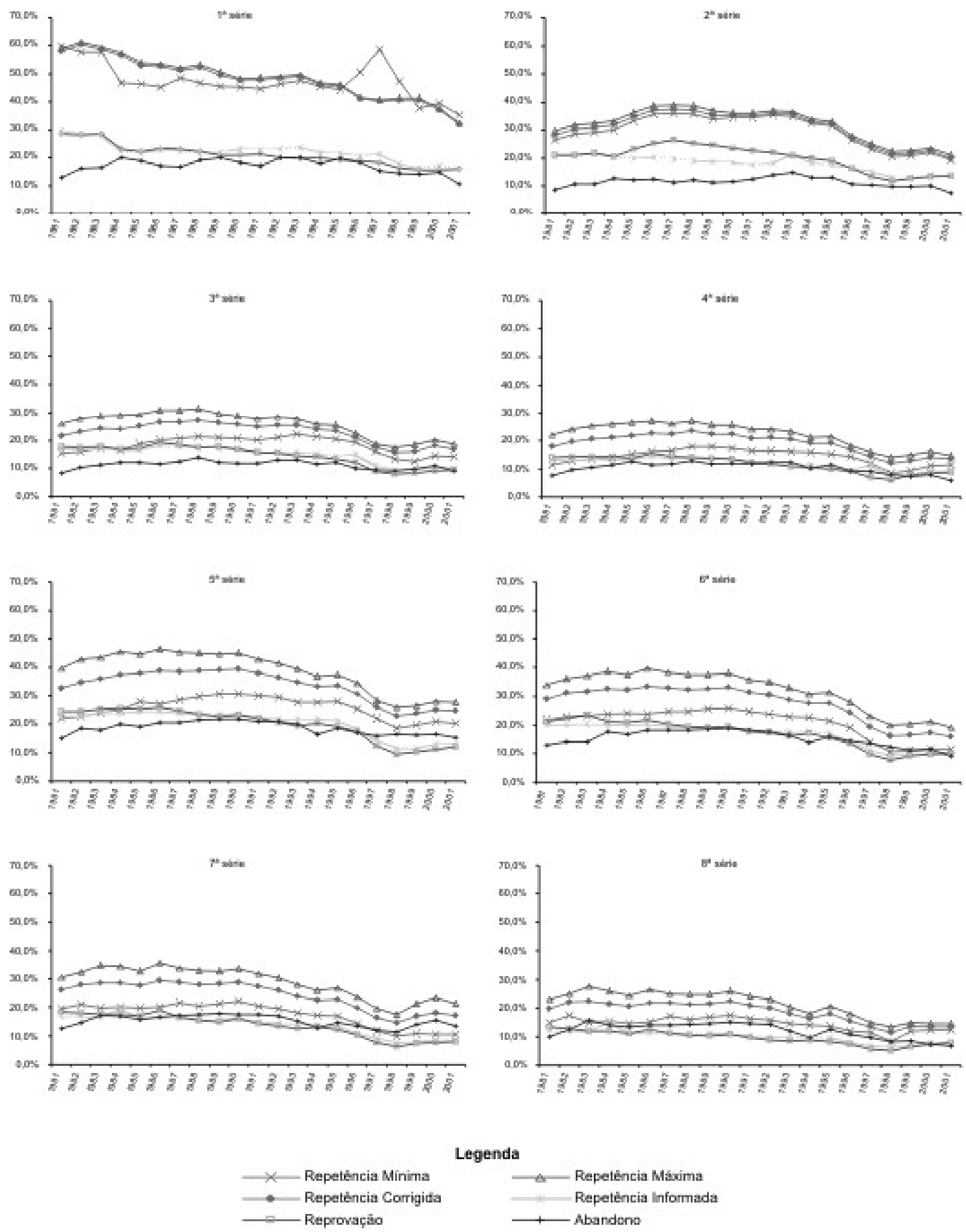

Figura 1.1 - Ensino fundamental regular - Taxas de repetência corrigida, mínima, máxima, informada, de reprovação e de abandono - Brasil, 1981-2001 

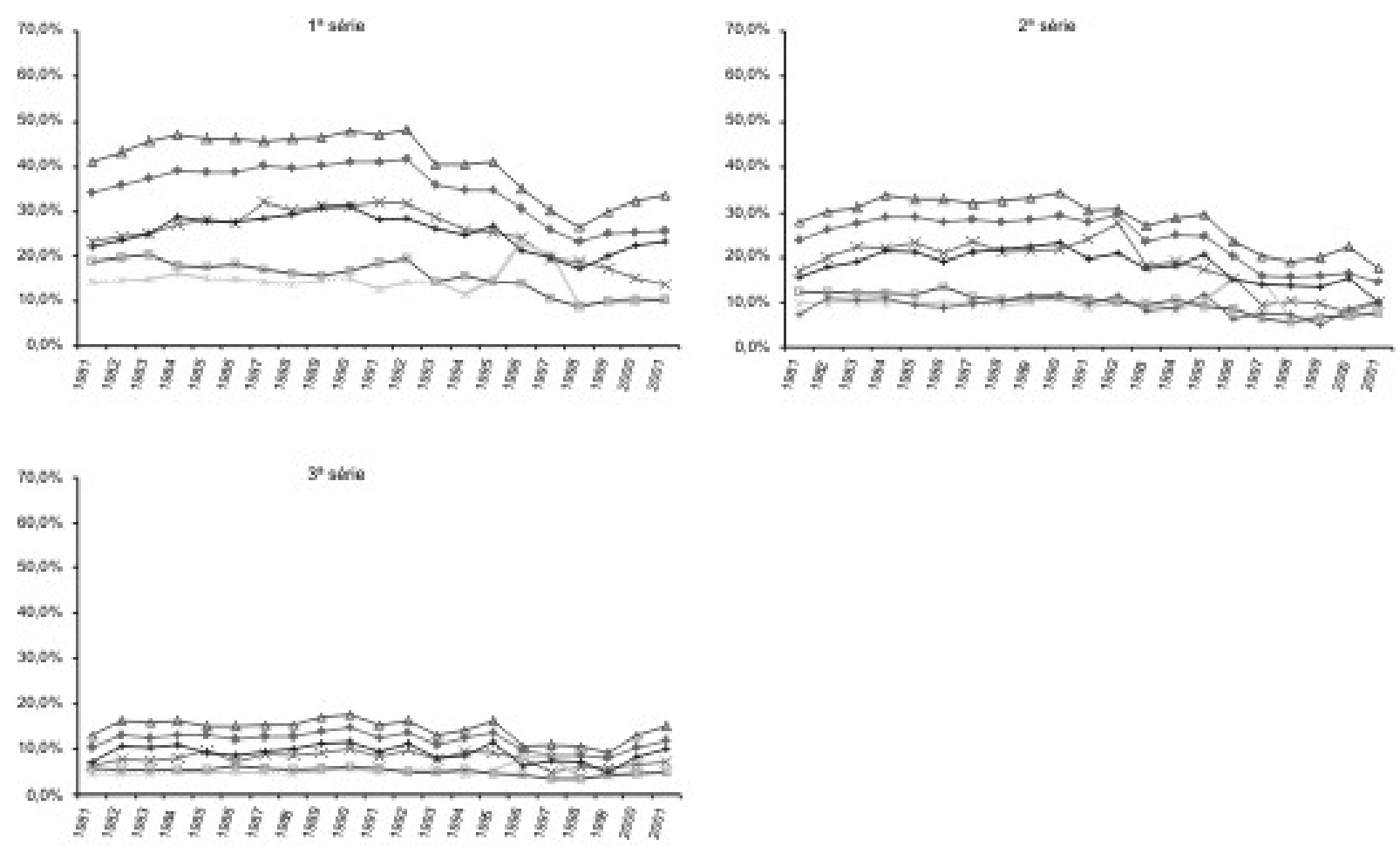

\section{Legenda}

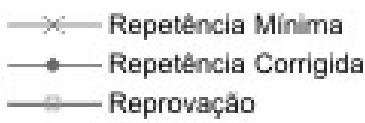
$-\Delta-$ Repetência Máxima
- Repetência Informada
+ Abandono

Figura 1.2 - Ensino médio regular - Taxas de repetência corrigida, mínima, máxima, informada, de reprovação e de abandono - Brasil, 1981-2001 

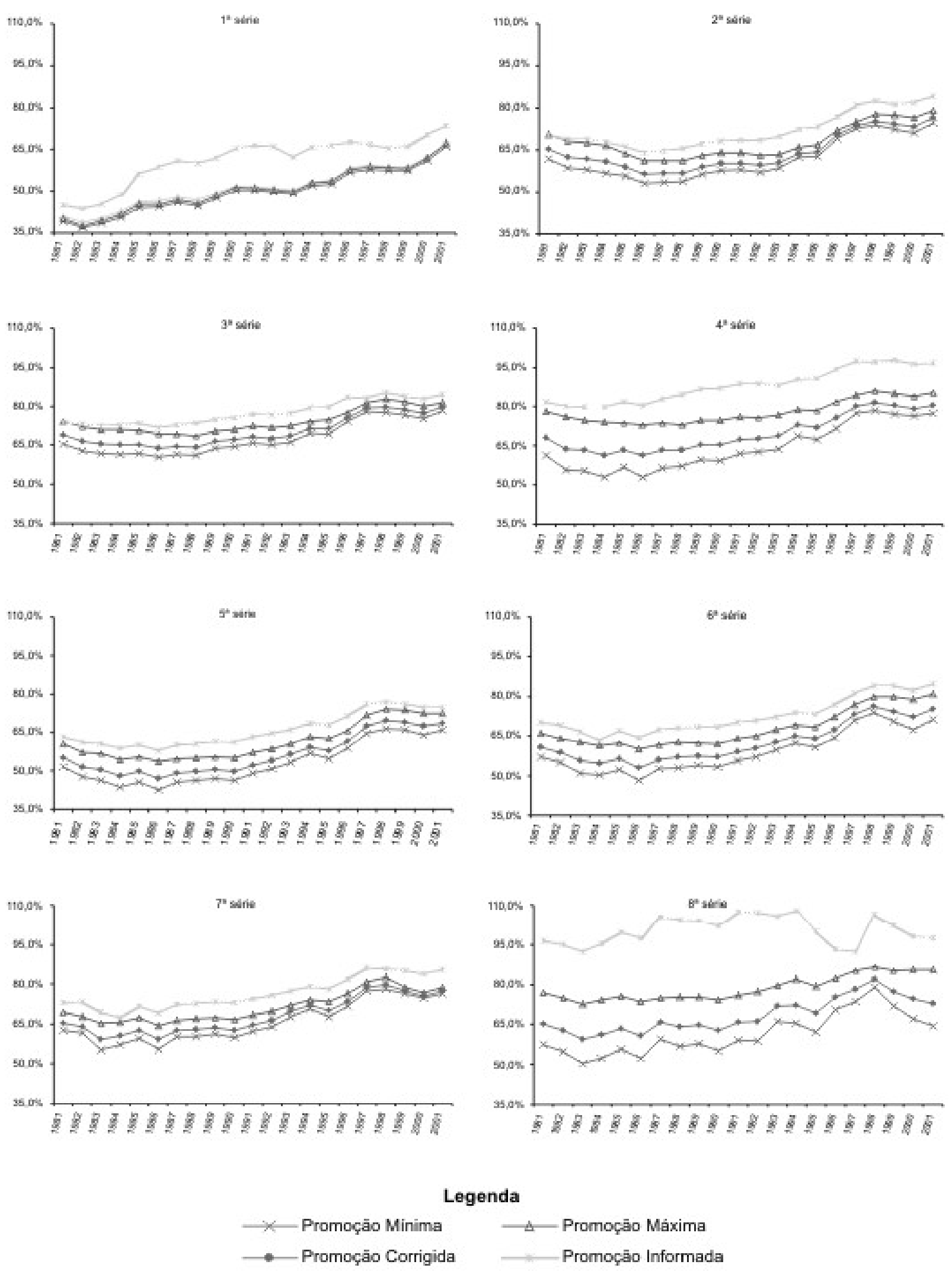

Figura 1.3 - Ensino fundamental regular - Taxas de promoção corrigida, mínima, máxima e informada - Brasil 1981-2001 

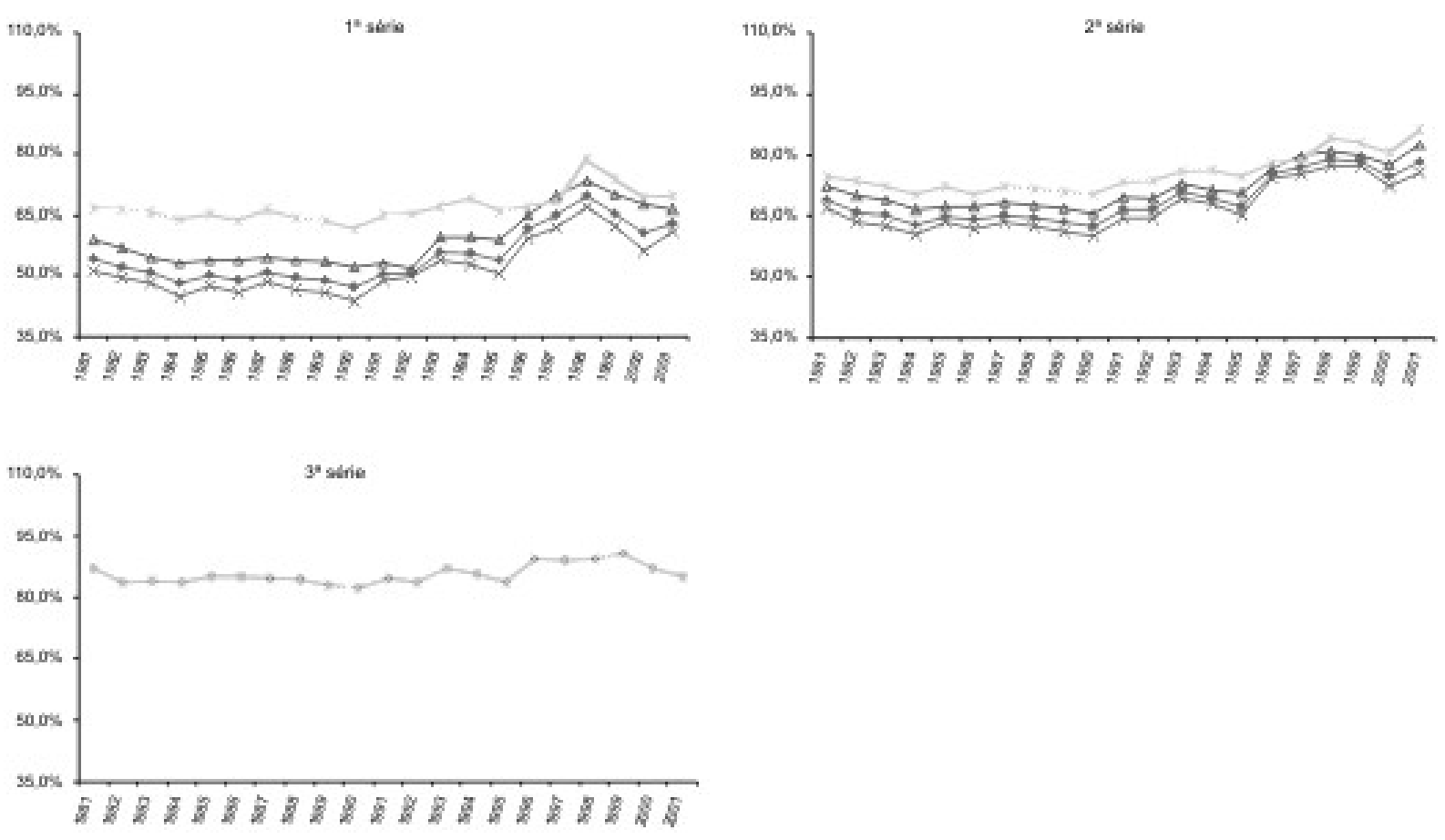

Legenda
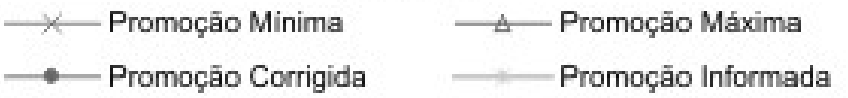

Figura 1.4 - Ensino médio regular - Taxas de promoção corrigida, mínima, máxima e informada - Brasil 1981-2001 

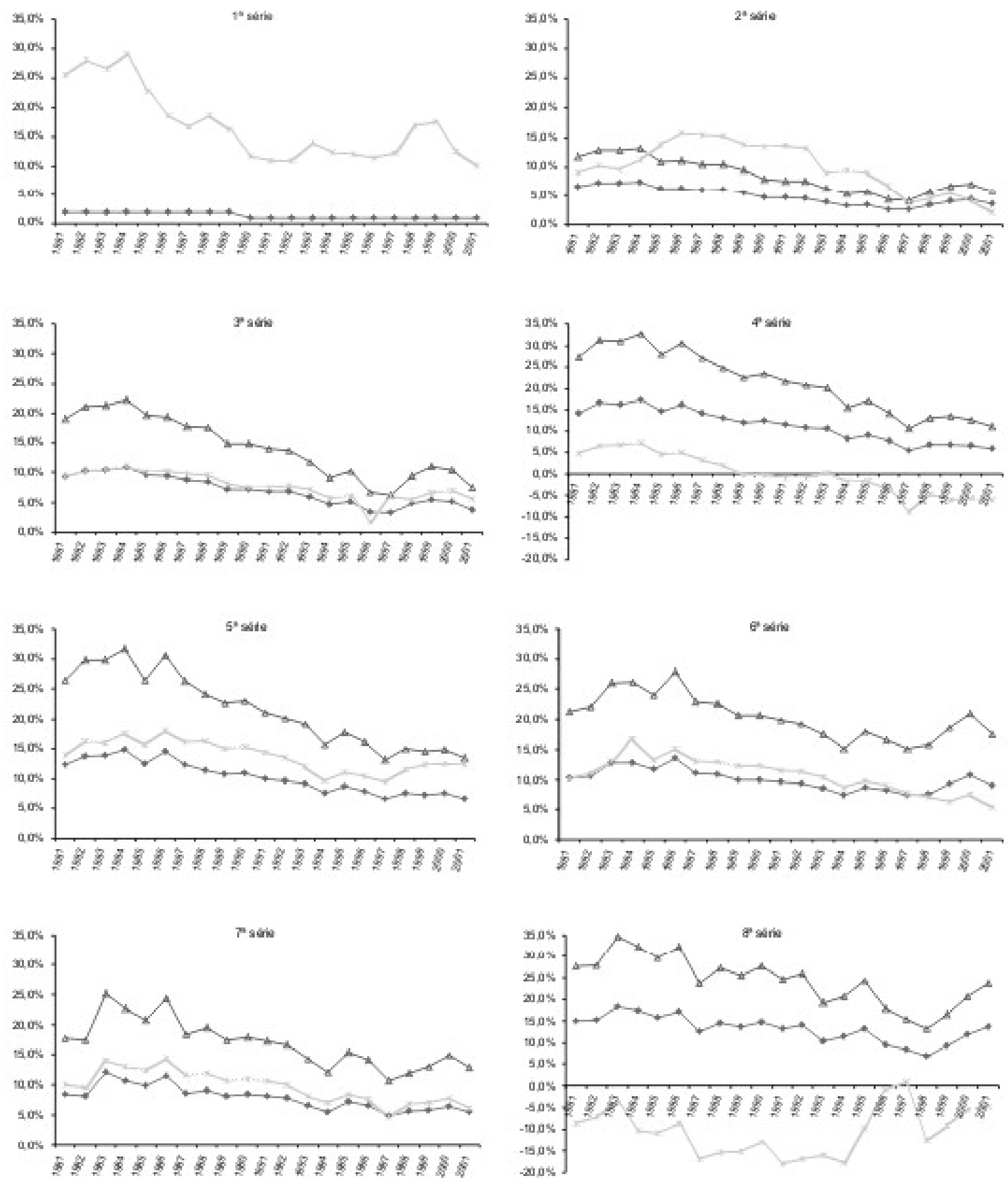

\section{Legenda}

$₫$ Evasão Máxima
Evasão Informada

Figura 1.5 - Ensino fundamental regular - Taxas de evasão corrigida, máxima e informada - Brasil 1981-2001 

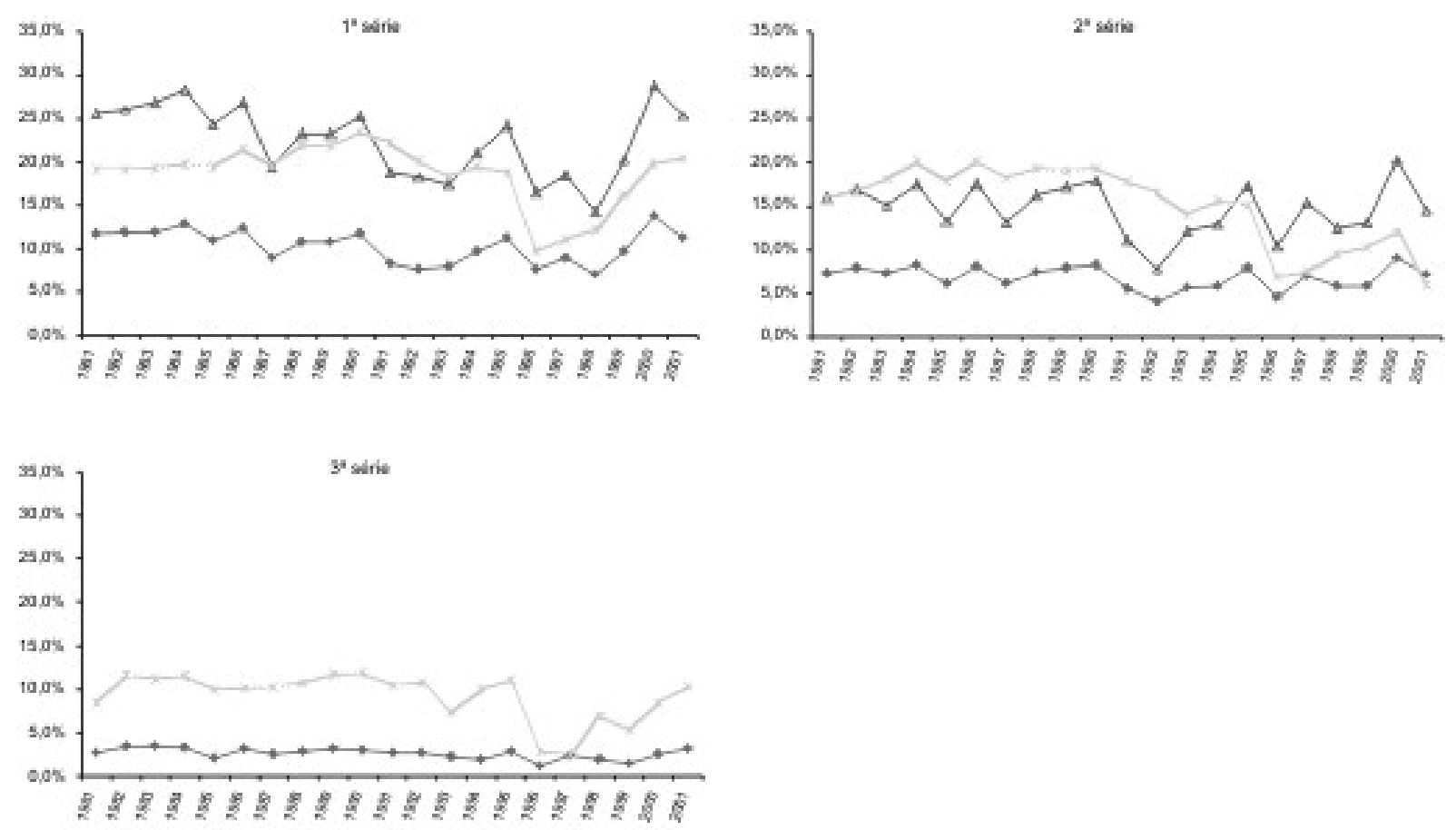

\section{Legenda}

$\triangle$ Evasāo Máxima
Evasāo Informada

Figura 1.6 - Ensino médio regular - Taxas de evasão corrigida, máxima e informada - Brasil 1981-2001 


\section{Anexo 2}

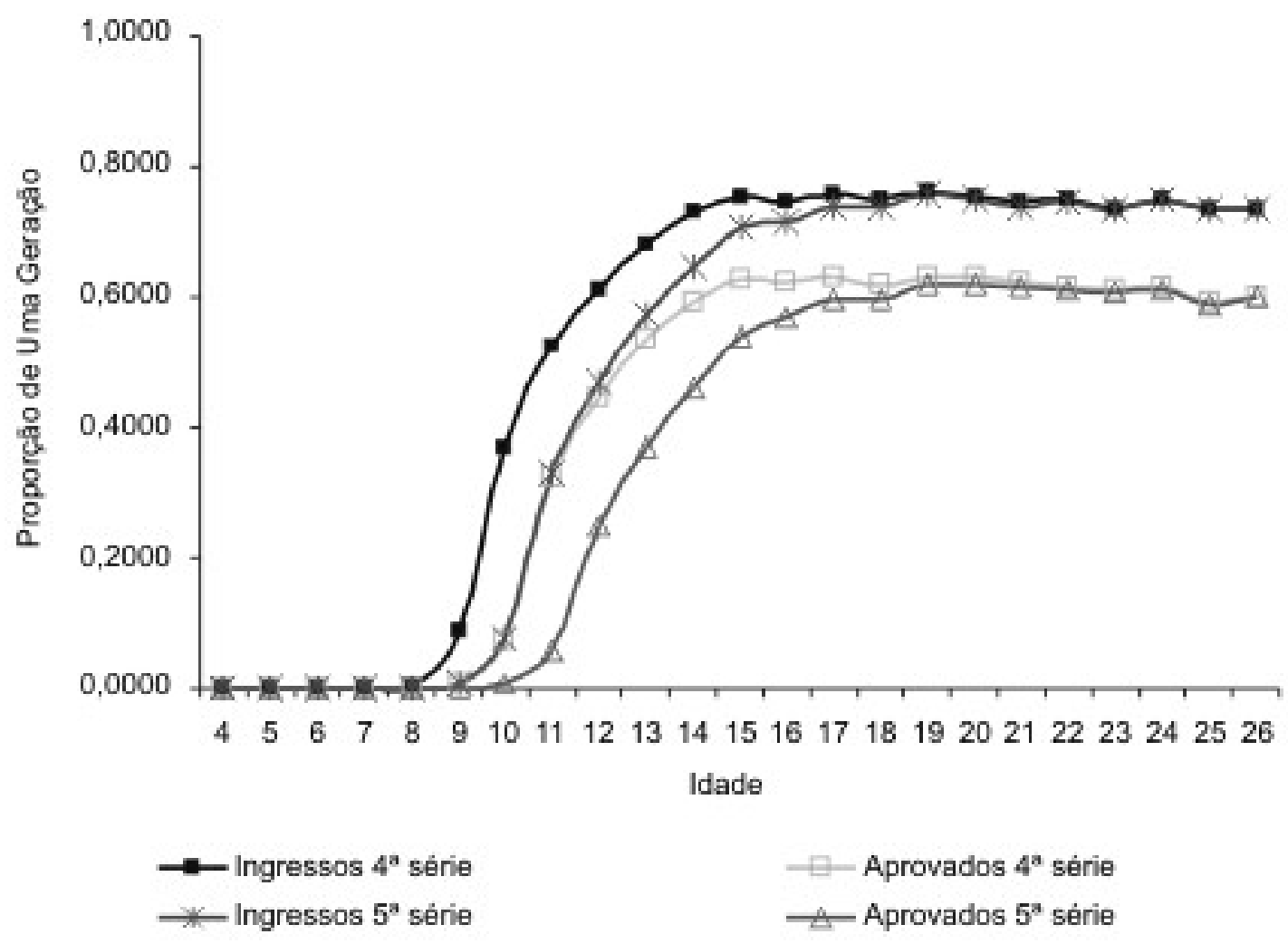

Fonte: Pnad. 1992.

Gráfico 2.1 - Proporção de ingressos e aprovados nas $4^{\mathrm{a}}$ e $5^{\mathrm{a}}$ séries - Brasil 1992 


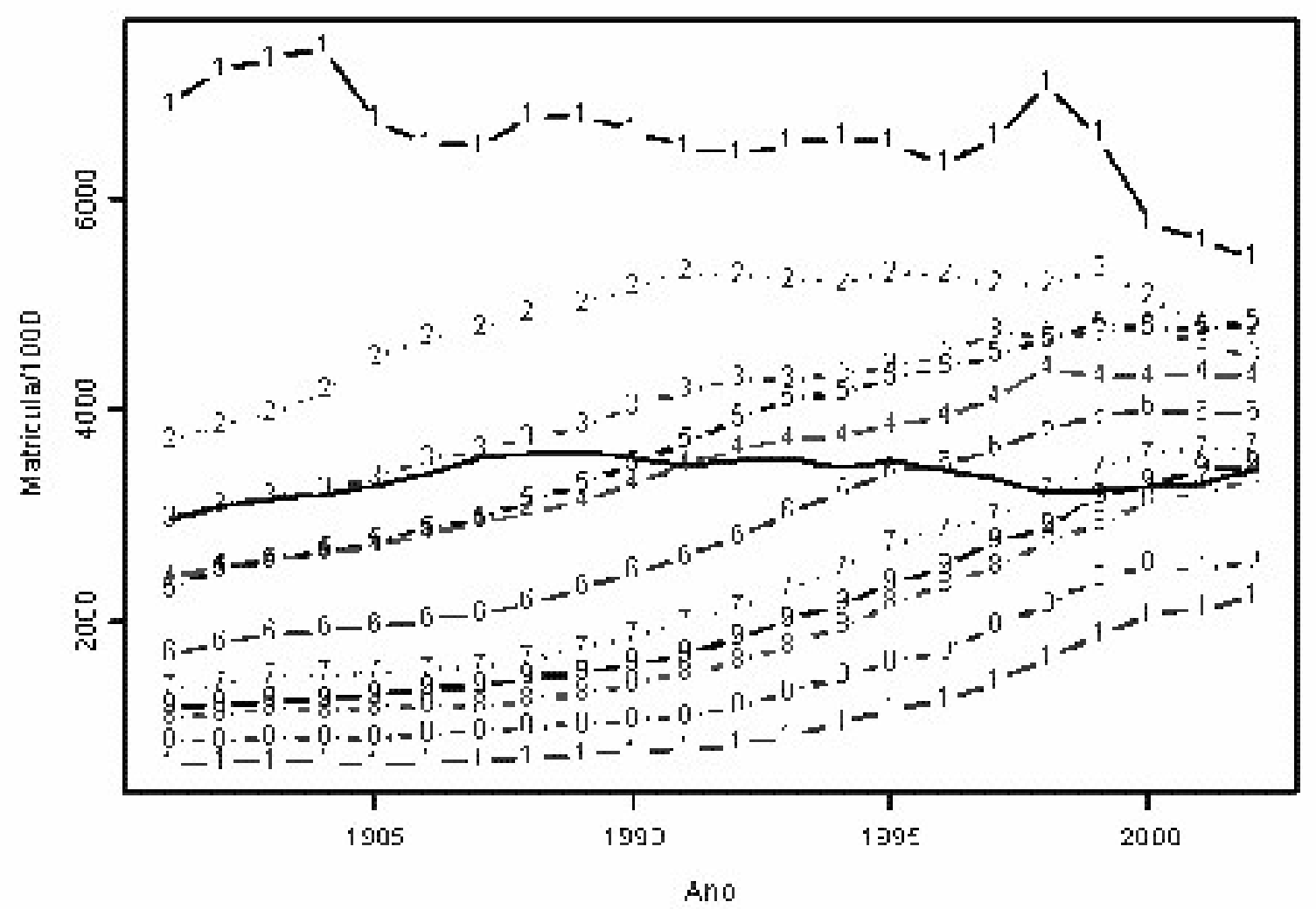

$-1-1^{n}$ série E.F. $\cdots 2 \cdots 2^{n}$ série E.F. . $-3 \cdot-3^{n}$ série E.F. $-4-4^{n}$ série E.F.

. $-5 .-5^{n}$ série E.F. $-6-6^{n}$ série E.F. $\cdots 7 \cdots 7^{n}$ série E.F. . - $\quad 8 .-8^{a}$ série E.F.

$-9-1^{n}$ série E.M. . - 0.- $2^{n}$ série E.M. $-1-3^{n}$ série E.M. - Coorte de 7 anos

Gráfico 2.2 - Matrículas por série - Brasil 1981-2002 

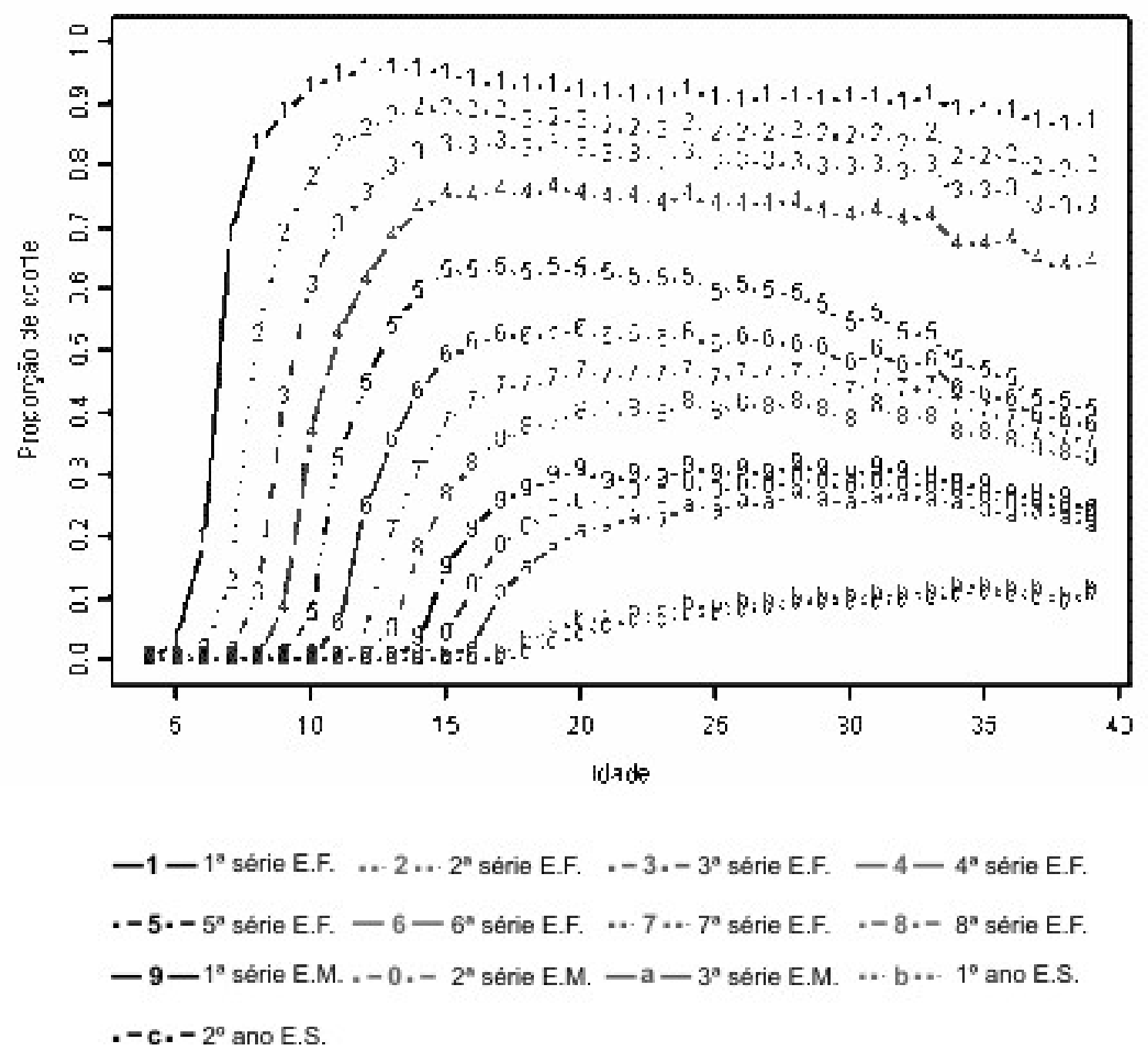

Gráfico 2.3 - Já ingressos por série - Brasil 1992 


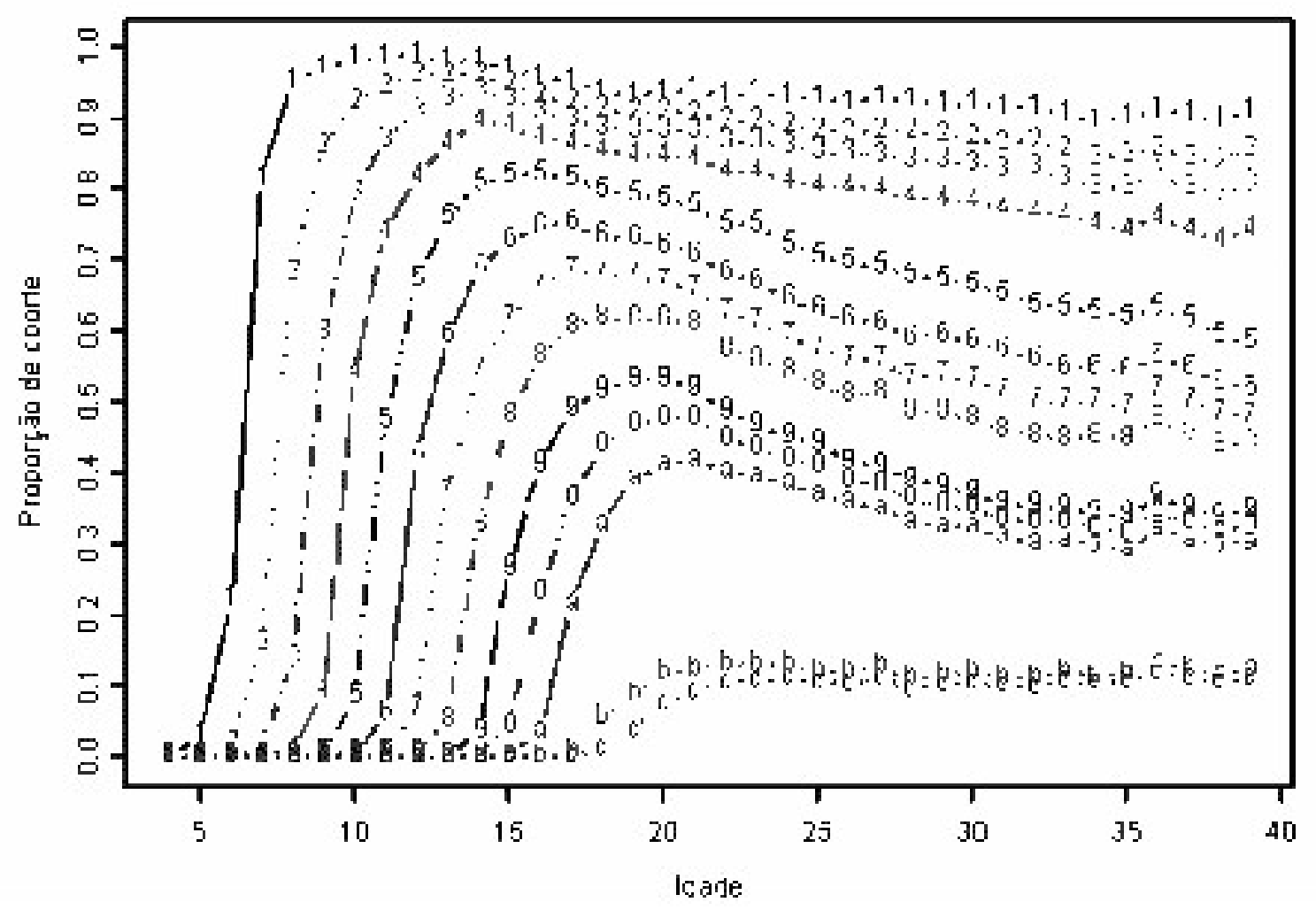

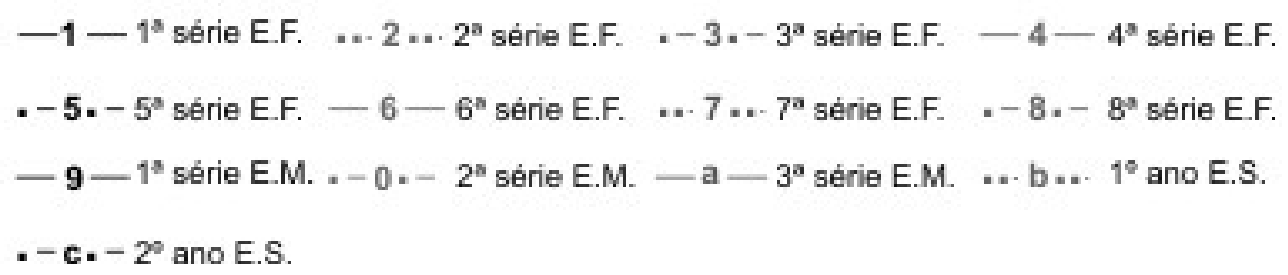

Gráfico 2.4 - Já ingressos por série - Brasil 2001 


\section{Anexo 3}

Tabela 3.1 - Taxas corrigidas de repetência, promoção, evasão de aprovados e evasão de não-aprovados - Brasil, 2001

\begin{tabular}{|c|c|c|c|c|}
\hline & Repetência & Promoçăo & $\begin{array}{r}\text { Evasåo de } \\
\text { aprovados }\end{array}$ & $\begin{array}{r}\text { Evasào de } \\
\text { năo-aprovados }\end{array}$ \\
\hline $1^{\mathrm{a}}$ série & 0,319 & 0,671 & 0,005 & 0,005 \\
\hline $2^{\mathrm{a}}$ série & 0,201 & 0,764 & 0,026 & 0,010 \\
\hline $3^{\mathrm{a}}$ série & 0,169 & 0,795 & 0,019 & 0,018 \\
\hline $4^{\mathrm{a}}$ série & 0,135 & 0,805 & 0,047 & 0,013 \\
\hline $5^{\mathrm{a}}$ série & 0,246 & 0,686 & 0,039 & 0,029 \\
\hline $6^{\mathrm{a}}$ série & 0,159 & 0,751 & 0,059 & 0,031 \\
\hline $7^{\mathrm{a}}$ série & 0,171 & 0,774 & 0,013 & 0,043 \\
\hline $8^{\mathrm{a}}$ série & 0,135 & 0,728 & 0,127 & 0,010 \\
\hline $9^{\mathrm{a}}$ série & 0,257 & 0,630 & 0,033 & 0,080 \\
\hline $10^{\mathrm{a}}$ série & 0,145 & 0,783 & 0,041 & 0,031 \\
\hline
\end{tabular}

Obs.: A partir de 2000 os dados foram corrigidos utilizando a informação de matrículas e rendimento das escolas que possuem ensino fundamental com 9 anos de duração (série 0 ).

Tabela 3.2 - Matrícula inicial segundo os censos escolares, com correções de consistência

\begin{tabular}{|c|c|c|c|c|c|c|c|c|c|c|c|}
\hline & $1^{4}$ sedrie & $2^{2}$ senie & $3^{2}$ serie & $4^{4}$ serie & $b^{4}$ serie & $6^{3}$ sêtrie & $7^{n}$ serie & $8^{3}$ secrie & $g^{\circ}$ serile & $10 \%$ serie & $11^{2}$ sebris \\
\hline 1981 & 6.896 .475 & 3.684 .889 & 2.976 .507 & 2.417 .984 & 2.314 .079 & 1.701 .139 & 1.371 .947 & 1.101 .009 & 1.209 .428 & 884.605 & 673.161 \\
\hline 1982 & 7.213 .626 & 3.861.492 & 3.098 .622 & 2.520 .832 & 2.503902 & 1.805530 & 1.423 .154 & 1.136 .726 & 1.233 .140 & & 690.300 \\
\hline 1983 & 7.316 .360 & 3.962 .241 & 174.049 & 2.594.912 & 2.588 .777 & 1.886.347 & 1.485 .671 & 1.182 .973 & 1.260 .613 & 502.558 & 687.149 \\
\hline 1984 & 7.419 .093 & 4.167 .170 & 3.255 .251 & 2.647 .385 & 2.680 .743 & 1.941 .238 & 1.508 .801 & 1.169.637 & 1.277 .922 & 914.746 & 683.998 \\
\hline 1985 & 6.745 .192 & 4.482 .069 & 3.363 .217 & 2.718 .149 & 2.745 .725 & 1.966 .933 & 1.528 .499 & 1.190.888 & 1.321 .964 & 506.445 & 674.606 \\
\hline 1986 & 6.515 .626 & 4.667 .224 & 3.535 .885 & 2.834 .479 & 2.890.090 & 2.033 .440 & 1.567 .410 & 1.225 .758 & 1.366 .745 & 963.598 & 38.384 \\
\hline 1987 & 6.504.867 & 4.763 .512 & 3.626 .047 & 2.947.AB1 & 2.978 .471 & 2.078 .906 & $1,570,490$ & & 1.399 .426 & 973.458 & 703.764 \\
\hline 1988 & 6.769 .039 & 4.904.661 & 3.719 .828 & 3.044 .689 & 3.151 .046 & 2.192 .192 & 1.657 .463 & 1.271 .764 & 1.491 .800 & 1.019 .065 & 738.101 \\
\hline 1989 & & & & & & & & & & & \\
\hline 1990 & 6.642 .037 & 5.135.384 & 4.017 .372 & 3.314 .326 & 3.496 .052 & 2.469 .560 & 1.866.842 & & 9.937 & 1.078 .900 & 782.614 \\
\hline 1991 & 6. 500.262 & 287.804 & 1.180 .871 & 3.483 .013 & & & & & & & 801.113 \\
\hline 1992 & 6.425 .701 & 5.257 .680 & 4284.846 & & & & & & & & \\
\hline 1983 & 6.534 .940 & 5.215 .654 & 4.283 .936 & & 4.081 .936 & 4.730 & & & 835 & 1.3 & \\
\hline 1594 & $6.581,322$ & & 4313.613 & & & & 2.505 .1 & & & 1.4 & 1,06 \\
\hline 1905 & 6.528 .892 & 5.269.875 & 4.407 .917 & 3.847 .634 & 3.696 & 3.423 .900 & 2.72 & & 864 & 1.6 & 1.18 \\
\hline 1896 & 6.328 .748 & 5.267 .950 & 4.483 .454 & & & 3.489205 & & & 2527.580 & 1.727 .171 & 1.274 .833 \\
\hline 1997 & 6.575 .734 & 154.094 & 4.724.389 & 4.113 .911 & .510 .872 & 3.630 .218 & 2.993. & & & 1.982 .640 & 1.445 .046 \\
\hline 1998 & 7.079 .742 & 5.170 .049 & 4.684 .209 & 4.399 .330 & 4.656 .172 & 3.834 .103 & 3.218 .865 & 2.750 .084 & 2.900 .429 & 2.164 .831 & 1.66 \\
\hline 1999 & 6.596 .785 & $5.317,321$ & 4.712 .596 & 4.311 .984 & 4.808 .240 & 3.931 .455 & 3.455 .729 & 2925.242 & 3.195,070 & 2.417 .720 & 1.884 .107 \\
\hline 2000 & & & & & & & & & & & \\
\hline 2001 & & & & & & & & & & & 2.138 .931 \\
\hline 2002 & 5.417.683 & 4.764 .926 & 4.492 .866 & 4.304 .217 & 4.814.111 & 3.960 .133 & 3.657 .202 & 3339.529 & 3.491 .666 & 2.595.001 & 2.239 .544 \\
\hline
\end{tabular}


Tabela 3.3 - Matrícula inicial de repetentes segundo os censos escolares

\begin{tabular}{|c|c|c|c|c|c|c|c|c|c|c|c|}
\hline & $1^{2}$ série & $2^{4}$ série & $3^{a}$ série & 'séfie & série & série & ra série & série & série & $10^{2}$ série & $11^{2}$ série \\
\hline 1981 & 1.982 .203 & 5.631 & .078 & & & & & & 55 & & \\
\hline 1982 & 2.040 .2 & & & & & & & & & & \\
\hline 1983 & 2.050 & & & & & & & & & & \\
\hline 1984 & 2.060 .034 & 859. & 35 & & & & & & & & \\
\hline 1985 & 1. & & & & & & & & & & \\
\hline 1986 & 1. & & & & & & & & & & \\
\hline 1987 & 1.48 & & & & & & & & & & \\
\hline 1988 & 1.45 & & & & & & & & & & \\
\hline 1989 & 1. & & & & & & & & & & \\
\hline 1990 & 1.48 & & & & & & & & & & \\
\hline 1991 & 52 & & & & & & & & & & \\
\hline 1992 & $1.46 t$ & & 6 & & & & & & & t & \\
\hline 1993 & 47 & & & & & & & & & & \\
\hline 1994 & & & & & & & & & & & \\
\hline 1995 & 1.43 & & & & & & & & & & \\
\hline 1996 & 1.398 .029 & & 11 & 425.3 & & 4 & & 82 & & 66.608 & 62.2 \\
\hline 1997 & 1.310 .986 & & & & & & & & & & \\
\hline 1998 & 1.386 .05 & & & 4 & & 1 & 269. & & 52 & 75.898 & 123.976 \\
\hline 1999 & 1.246 .5 & & & & & & & & & & \\
\hline 2000 & 1.077 .110 & 6.571 & 4 & 3 & & & & 195.4 & 309.0 & 164.9 & 11 \\
\hline 2001 & & & & & & & & & & & \\
\hline & & & & & & & & & & & \\
\hline
\end{tabular}

Tabela 3.4 - Matrícula inicial de novos (ingressos) segundo os censos escolares

\begin{tabular}{|c|c|c|c|c|c|c|c|c|c|c|c|}
\hline & $1^{2}$ serie & $2^{\prime}$ série & $3^{*}$ sdrie & $4^{4}$ série & $5^{\circ}$ sedrie & $6^{2}$ serie & $7^{*}$ série & $\mathrm{g}^{2}$ serie & ot sene & $10^{2}$ série & $11^{*}$ séne \\
\hline 1981 & 4.913 .272 & 2.979 .258 & 2497.429 & 2.126 .113 & 1.846 .058 & 1.397 .453 & 1.160 .679 & 977.967 & 1.061 .673 & 808.806 & 645. 161 \\
\hline 1982 & 5. 173.374 & $3.096 .7 \mathrm{B2}$ & 2.595 .971 & 2.197 .277 & 1.978 .540 & 1.467 .914 & 1.190 .530 & 1.001 .532 & 1.060 .526 & 806.102 & 659.252 \\
\hline 1983 & 5.265.217 & 3.139 .927 & 2.652 .041 & 2.257 .360 & 2.019 .278 & $1,527,565$ & 1.246236 & 1,046231 & 1.079 .895 & & \\
\hline 1984 & 5.359 .059 & 3.307 .253 & 2.713 .886 & 2.295 .836 & 2.067 .107 & 1.561 .292 & 1.260 .555 & 1.031 .346 & 1.089099 & 827.646 & 651.798 \\
\hline 1986 & 5.093 .946 & 3.617 .430 & 2.833 .610 & 2.368 .713 & 2.107 .324 & 1.571 .049 & 1.231956 & 1.015 .518 & $1,114,047$ & 817.945 & 641.80 \\
\hline 1986 & 5.073 .961 & 3.773 .983 & 2.972 .867 & 2.462 .705 & 2.223 .745 & 1.646 .963 & 1.311 .376 & 1.090 .714 & 1.186 .629 & 863.698 & 652.954 \\
\hline 1987 & 5.020 .764 & 3.815 .908 & 2.987 .261 & 2.534 .294 & 2.274 .976 & 1.666 .229 & 1.312 .535 & $1,073.630$ & 1.192 .653 & 882.158 & 669.764 \\
\hline 1988 & 5.316.068 & 3.952 .831 & 3.088 .188 & 2.638 .352 & 2.441 .302 & 1.789 .436 & 1.404 .731 & 1.135.891 & 1.282 .921 & 926.141 & 702.832 \\
\hline 1989 & 5.334 .458 & 4.051 .408 & 3217.006 & 2.727 .453 & 2.567 .283 & 1.906 .065 & $1,493.182$ & 1.203 .863 & $1,331.795$ & 953.453 & 729.482 \\
\hline 1990 & 5.157 .081 & 4.195 .968 & 3.359 .385 & 2.881 .263 & 2.720 .758 & 2.022 .469 & 1.590617 & 1.283 .686 & 1.396270 & 974.872 & 742.146 \\
\hline 1991 & 4.979 .704 & 4.340 .506 & 3.501 .770 & 3.035 .112 & 2.874 .231 & 2.138 .873 & 1.688051 & 1.363869 & $1,460.745$ & 996.292 & 754811 \\
\hline 1992 & 4.958 .879 & $4,321,783$ & 3.629 .683 & 3.211 .234 & 3.086 .370 & 2.333913 & 1.839 .902 & 1.480 .071 & 1,640655 & $1,110.722$ & 815.149 \\
\hline 1993 & 5.060 .649 & 4.252 .049 & 3.604 .377 & 3.271 .667 & 3.227 .794 & 2.525 .926 & 1.991 .918 & 1.615 .815 & 1.753 .199 & 1.214 .832 & 887.997 \\
\hline 1594 & 5.035 .602 & 4.076 .858 & 3.639 .108 & 3.301 .427 & 3.263 .855 & 2.701 .205 & 2.177914 & 1.781 .537 & $1,884.164$ & 1,353613 & 1.010 .443 \\
\hline 1995 & 5.097 .369 & 4.332 .287 & 3.757 .279 & 3.416 .313 & 3.392 .516 & 2.051.832 & 2.380 .624 & 1.981.313 & 2.115 .123 & 1.506 .168 & 1.138 .840 \\
\hline 1996 & 4.930 .719 & 4.337 .794 & 3.863 .533 & 3.509 .807 & 3.486 .805 & 2.910 .381 & 2.510 .100 & 2.133533 & 2.169.512 & 1.560 .563 & 1.212 .675 \\
\hline 1997 & 5.264 .748 & 4.292.110 & 4.047 .965 & 3.739 .180 & 3.713 .807 & 3.138 .970 & 2.686 .129 & 2.346 .359 & 2.181 .746 & 1.696 .970 & 1.342 .434 \\
\hline 1998 & 5.683 .689 & 4.379 .690 & 4.171 .396 & 3.924 .231 & 4.008 .014 & 3.431 .992 & 2.949 .280 & 2.581 .593 & 2.332 .677 & 1.888933 & 1.539 .097 \\
\hline 1999 & 5.350 .222 & 4.639.310 & 4.263 .477 & 3.979 .190 & 4.277 .589 & 3.584 .347 & 3.215 .548 & 2.758952 & 2.928 .879 & 2.279 .335 & 1.821.206 \\
\hline 2000 & 4.720 .430 & 4.356 .847 & 4.329 .472 & 3.949 .876 & 4.207 .908 & 3.656618 & 3.305375 & 2.941 .383 & 2.996818 & 2.367 .746 & 2.002 .328 \\
\hline 2001 & 4.609 .679 & 4.077 .277 & 4.136 .200 & 3.945951 & 4.152 .765 & 3.556 .515 & 3.320998 & 2.993690 & 3.078 .126 & 2.292 .475 & 2.042 .483 \\
\hline 2002 & 4.502 .970 & 4.116 .656 & 4.031 .462 & 3.901 .862 & 4.197 .303 & 3.560 .352 & 3.352 .639 & 3.096 .198 & 3.132286 & 2.389 .097 & 2.137 .067 \\
\hline
\end{tabular}


Tabela 3.5 - Aprovados segundo os censos escolares

\begin{tabular}{|c|c|c|c|c|c|c|c|c|c|c|c|}
\hline & $1^{*}$ senie & serie & $3^{*}$ serie & $4^{2}$ serie & séne & $6^{\circ}$ series & $7 "$ série & $8^{*}$ série & ge sèrie & $10^{\circ}$ genrie & $11^{1 "}$ gérie \\
\hline 981 & 4.041 .693 & .596 .876 & 204.033 & .883 .842 & .398 .366 & 124.202 & 51.771 & 67.851 & 12.411 & 137.088 & 85.167 \\
\hline 1982 & 027.691 & 632.300 & 230.805 & 02 & & .153 .058 & & & & & \\
\hline 1983 & .013 .489 & & & & & & & & & & \\
\hline 1984 & 4.240 .750 & & & & & & & & & & \\
\hline 1985 & & & & & & & & & & & \\
\hline 1986 & & & & & & & & & & & \\
\hline 1987 & & & & & & & & & & & \\
\hline 1988 & 3.981 .489 & 3.056 .124 & 2.552 .951 & 2.215 .605 & 1.73 & & & & & & \\
\hline 1989 & 4.007. & & & & & & & & & & \\
\hline 1990 & 4.0329 & & 2 & & & & & & & & \\
\hline 1991 & & & & & & & & & & & \\
\hline 1992 & 3.865 .192 & 3.367 .706 & 3.063 .713 & & & & & 1.2 & & 14 & \\
\hline 1993 & & & & & & & & & & & \\
\hline 190 & & & & & & & & & & & \\
\hline 1996 & & & & & & & & & & & \\
\hline 1996 & 3.9 & & & & & & & & & & \\
\hline 1997 & & & & & & & & & & & \\
\hline 1998 & 4.916 .335 & 4.041 .820 & & & & & & & 2.132 .341 & 1.749 .700 & 1486.320 \\
\hline 1999 & 4.641 .484 & 4.113.508 & 3.850 .336 & 3.664 .779 & 3.537 .409 & 3.135.994 & 2.722 .774 & 2.493 .314 & 2.237 .993 & 1.933 .448 & 1.707 .149 \\
\hline 2000 & 4.039 .903 & 3.864 .040 & 3.803979 & 3.607 .120 & & 3.186.427 & & 2.682 .8 & 2.233 .944 & 1.963255 & 1.808 .855 \\
\hline 2001 & 4.128.514 & 3.774 .254 & 3.761.420 & 3.699 .857 & 3.453 .792 & 3. $209.5 \mathrm{~B} 2$ & 2.849 .036 & 2.754 .818 & 2.282 .490 & 2.043 .951 & 1.815 .913 \\
\hline
\end{tabular}

Tabela 3.6 - Reprovados segundo os censos escolares

\begin{tabular}{|c|c|c|c|c|c|c|c|c|c|c|c|}
\hline & 1" série & $2^{2}$ série & $3^{n}$ série & $4^{4}$ série & $5^{2}$ série & $6^{\text {b serie }}$ & $7^{\circ}$ série & $8^{a}$ série & $g^{*}$ serie & $10^{3}$ série & $11^{3}$ serile \\
\hline 1981 & 1.954 .728 & 783.839 & 29.074 & 345.332 & 67.842 & 58.130 & 250.614 & 145.915 & 228.755 & 108.815 & 38.440 \\
\hline 1982 & & & & & & & & & & & \\
\hline 1983 & 085.309 & 855.434 & 561.048 & & & & & & & & \\
\hline 1984 & 700.420 & 856.183 & 554.562 & 383.123 & 689.293 & & & 138.864 & & & \\
\hline 1985 & 104704 & 1.039 .584 & & & & & & & & & \\
\hline 1986 & 523.133 & & & & & & & & & & \\
\hline 1987 & & & & & & & & & & & \\
\hline 1988 & 1.499 .578 & 1.243 .876 & 649 & 43: & 06 & & & & & & \\
\hline 1989 & & & & & & & & & & & \\
\hline 1990 & 1.396 .458 & 1.207 .725 & 680.466 & 209 & & & & & & & \\
\hline 1991 & 1.38 & & & & & & & & & & \\
\hline 1992 & & & & & & & & 566 & & & \\
\hline 1993 & & & & & & & & & & & \\
\hline 1994 & & & & & & & & & & & \\
\hline 1995 & 1.240 .199 & 1.004 .780 & 582.015 & & & & & & & & 55.729 \\
\hline 1996 & 1.190 .135 & & & & & & & & & & \\
\hline 1997 & & & & & & & & & & & \\
\hline 1998 & & & & & & & & & & & \\
\hline 1999 & 1.023 .016 & 683.056 & 398.319 & 343.294 & 499.037 & & & & & & 82.127 \\
\hline 2000 & & & & & & & & & & 179.826 & 97.154 \\
\hline 2001 & 886.346 & 649.518 & 437.138 & 389.401 & 573.902 & 389.787 & 286.136 & 248.407 & 352.478 & 187.986 & 106.246 \\
\hline
\end{tabular}


Tabela 3.7 - Afastados por abandono (matrícula inicial - aprovados - reprovados)

\begin{tabular}{|c|c|c|c|c|c|c|c|c|c|c|c|}
\hline & $1^{\text {" série }}$ & $2^{\text {" }}$ série & $3^{a}$ série & $4^{x}$ série & $5^{n}$ série & $6^{a}$ série & $7^{\prime \prime}$ série & $8^{\prime \prime}$ série & $9^{n}$ série & $10^{2}$ série & $11^{a}$ série \\
\hline 1981 & 899.054 & 314.174 & 243.400 & 188.810 & 347.872 & 218.807 & 169.562 & 107.243 & 268.262 & 138.702 & 49.525 \\
\hline 1982 & 1.166 .016 & 409.556 & 322.756 & 248.136 & 459.989 & 252.852 & 206.067 & 140.402 & 290.820 & 160.370 & 74,300 \\
\hline 1983 & 1.217 .562 & 429.083 & 355.423 & 278.695 & 467.158 & 263.323 & 254.882 & 184.092 & 317.139 & 172.558 & 71.149 \\
\hline 1984 & 1.477 .883 & 534.455 & 395.255 & 303.948 & 535.065 & 338.916 & 256.492 & 163.555 & 368.713 & 197.574 & 74.215 \\
\hline 1985 & 1.263 .537 & 540.870 & 408.374 & 341.718 & 527.046 & 329.315 & 240.042 & 159.148 & 372.114 & 192.700 & 62.946 \\
\hline 1986 & 1.105 .744 & 580.874 & 413.649 & 325.790 & 593.094 & 370.430 & 259.470 & 170.498 & 384.928 & 183.661 & 60.235 \\
\hline 1987 & 1.096 .807 & 540.512 & 446.190 & 349.610 & 610.872 & 378.367 & 270.194 & 168.588 & 398.644 & 205.077 & 67.808 \\
\hline 1988 & 1.287 .972 & 604.661 & 517.256 & 396.052 & 674.053 & 397.875 & 290.491 & 182.520 & 438.417 & 223.163 & 74.110 \\
\hline 1989 & 1.354 .741 & 568.915 & 468.402 & 369.527 & 719.995 & 429.649 & 310.087 & 195.072 & 471.716 & 233.958 & 85.898 \\
\hline 1990 & 1.212 .673 & 598.283 & 479,503 & 399.826 & 761.256 & 461.923 & 325.807 & 216.845 & & 250.387 & 90,171 \\
\hline 1991 & 1.115 .737 & 659.426 & 500.655 & 409.842 & 776.143 & 474.545 & 345.263 & 222.356 & 485.200 & 220.195 & 76.275 \\
\hline 1992 & 1.278 .306 & 737.474 & 561.661 & 452.702 & 815.575 & 495.330 & 361.897 & 231.254 & 531.526 & 254.254 & 96.198 \\
\hline 1993 & 1.315 .033 & 770.592 & 561.246 & 462.234 & 817.893 & 497.052 & 352.616 & 213.972 & 530.327 & 238.051 & 75.757 \\
\hline 1901 & 1.170 .983 & 678.040 & 496.386 & 303.273 & 685.141 & 114,018 & 323.415 & 105.381 & 540.910 & 272.577 & 93.102 \\
\hline 1995 & 1.277 .015 & 691.778 & 539.745 & 448.189 & 789.769 & 544.469 & 397.340 & 271.922 & 634.199 & 335.775 & 137.009 \\
\hline 1996 & 1.145 .396 & 562.475 & 456.442 & 369.500 & 747.740 & 498.146 & 381.517 & 249.949 & 535.042 & 261.091 & 81.928 \\
\hline 1997 & 1.005 .066 & 541.258 & 454.844 & 371.791 & 718.359 & 485.303 & 355.609 & 239.393 & 546.589 & 275.761 & 108.266 \\
\hline 1998 & 1.019 .208 & 508.178 & 437.620 & 345.590 & 762.777 & 472.761 & 369.851 & 226.829 & 511.763 & 293.310 & 121.382 \\
\hline 1999 & 932.285 & 520.757 & 464,331 & 313.911 & 771.794 & 435.419 & 484.299 & 248.468 & 639.543 & 321.662 & 94,831 \\
\hline 2000 & 859.356 & 507.857 & 530.814 & 340.085 & 789.396 & 455.238 & 556.394 & 228.707 & 740.709 & 389.663 & 173.620 \\
\hline 2001 & 587.058 & 358.617 & 426.456 & 252.751 & 735.324 & 364.206 & 487.378 & 218.037 & 803.565 & 247.536 & 216.772 \\
\hline
\end{tabular}

Tabela 3.8 - Evadidos aprovados segundo os censos escolares

\begin{tabular}{|c|c|c|c|c|c|c|c|c|c|c|c|}
\hline & $1^{\text {"n serie }}$ & $2^{a}$ série & $3^{2}$ série & $4^{4}$ série & $5^{n}$ série & $6^{\circ}$ série & Te serie & $8^{3}$ série & $g^{2}$ série & $10^{3}$ série & $11^{3}$ sedrie \\
\hline 1981 & 944.911 & 905 & 6.756 & -94.698 & -69.549 & -66.328 & -49.761 & -212.675 & -93.691 & -22.164 & 0 \\
\hline 1982 & 887.664 & -19.741 & -26.554 & -107.776 & -96.647 & -93.178 & -84.855 & -227.511 & -117.677 & -33.549 & 0 \\
\hline 1983 & 706.236 & -46.162 & -38.258 & -127.945 & -97.819 & -78.641 & -60.365 & -232.183 & -141.695 & -29.798 & 0 \\
\hline 1984 & 623.360 & -57.078 & -63.279 & -147.010 & -114.664 & .39 .969 & -26.826 & -246.829 & -139.966 & -34.243 & 0 \\
\hline 1985 & 212.968 & -71.252 & -85.057 & -226.364 & -125.930 & 90.942 & -66.963 & -288.080 & -149.607 & -44.064 & 0 \\
\hline 1986 & 70.841 & -80.445 & -90.070 & -208.097 & -117.628 & -90.070 & -70.028 & -290.041 & -135.792 & -27.857 & 0 \\
\hline 1987 & -48.017 & -129.712 & -124.487 & -273.080 & -159.861 & -121.737 & -96.308 & -372.703 & -164.873 & -40.606 & 0 \\
\hline 1988 & -69.919 & -160.882 & -174.492 & -351.678 & -171.678 & -120.714 & -94.160 & -375.491 & -153.879 & -40.628 & 0 \\
\hline 1989 & -188.760 & -165.138 & -176.101 & -380.660 & -196.075 & -139.381 & -107.194 & -387.954 & -152.828 & -43.682 & 0 \\
\hline 1990 & -307.602 & -169.394 & -177.709 & -409.640 & -220.472 & -158.047 & -120.229 & -400.417 & -151.777 & -46.738 & 0 \\
\hline 1991 & -321.783 & -196.878 & -192384 & -447.169 & $-227,385$ & -160.572 & -124.853 & -496.893 & -206.698 & -42.865 & D \\
\hline 1992 & -386.857 & -236.671 & -207.954 & -468.957 & -236.939 & -159.065 & -130.064 & -492.574 & -251.299 & .51 .503 & 0 \\
\hline 1993 & -149.193 & -281.230 & -206.587 & -413.111 & -226.583 & -140.786 & -124.388 & -470.607 & -153.232 & -36.399 & 0 \\
\hline 1984 & -250.175 & -283.197 & -217.718 & -435.311 & -229.504 & -145.410 & $-127,470$ & -513.584 & -211.499 & -74.256 & D \\
\hline 1995 & -326.116 & -290.416 & -223.650 & -470.315 & -227.241 & -162.665 & $-134,325$ & -449.283 & -165.477 & -66.987 & 0 \\
\hline 1996 & -298.893 & -201.218 & -252.148 & -504.422 & -248.868 & -169.422 & -150.009 & -257.964 & -54.683 & -23.038 & 0 \\
\hline 1997 & -1.795 & -252.799 & -79.127 & -551.993 & -192.807 & -153.883 & -169.643 & -181.406 & 42.165 & 24.367 & 0 \\
\hline 1998 & 277.025 & -221.657 & -113211 & -501.431 & -128.325 & -146.728 & -104.869 & -543.297 & -146.994 & -71.506 & 0 \\
\hline 1999 & 284.637 & -215.964 & $=99.540$ & -553.129 & -119.209 & -166.381 & -218.609 & $=503.504$ & -129.753 & -68.880 & 0 \\
\hline 2000 & -37.374 & -272.160 & -141.982 & -545.645 & -120.081 & -134.571 & -250.308 & -395.222 & -58.531 & -79.228 & 0 \\
\hline 2001 & 11.858 & -257.208 & -140.442 & -497.446 & -106.560 & -143.057 & -246.162 & -377.468 & -106.607 & -93.106 & D \\
\hline
\end{tabular}


Tabela 3.9 - Estimativa dos tamanhos das coortes de 7 anos de 1981 a 2002 Estas estimativas estão sujeitas a correções

\begin{tabular}{|l|c|}
\hline & Coorle de 7 anos \\
\hline 1981 & 2.982 .305 \\
\hline 1982 & 3.093 .695 \\
\hline 1983 & 3.153 .667 \\
\hline 1984 & 3.203 .399 \\
\hline 1985 & 3.288 .302 \\
\hline 1986 & 3.392 .353 \\
\hline 1987 & 3.556 .679 \\
\hline 1988 & 3.606 .426 \\
\hline 1989 & 3.619 .928 \\
\hline 1990 & 3.551 .516 \\
\hline 1991 & 3.497 .668 \\
\hline 1992 & 3.521 .891 \\
\hline 1993 & 3.560 .831 \\
\hline 1994 & 3.461 .413 \\
\hline 1995 & 3.524 .814 \\
\hline 1996 & 3.433 .809 \\
\hline 1997 & 3.367 .200 \\
\hline 1998 & 3.230 .301 \\
\hline 1999 & 3.245 .677 \\
\hline 2000 & 3.300 .664 \\
\hline 2001 & 3.320 .105 \\
\hline 2002 & 3.445 .580 \\
\hline
\end{tabular}

Tabela 3.10 - Proporção de novos, segundo os censos escolares, em relação às coortes de 7 anos

\begin{tabular}{|c|c|}
\hline & Proporção de nowos \\
\hline 1981 & 1,65 \\
\hline 1982 & 1,67 \\
\hline 1983 & 1,67 \\
\hline 1984 & 1,67 \\
\hline 1985 & 1,56 \\
\hline 1986 & 1,50 \\
\hline 1987 & 1,41 \\
\hline 1988 & 1,47 \\
\hline 1989 & 1,47 \\
\hline 1990 & 1,45 \\
\hline 1991 & 1,42 \\
\hline 1992 & 1,41 \\
\hline 1993 & 1,42 \\
\hline 1994 & 1,45 \\
\hline 1995 & 1,45 \\
\hline 1996 & 1,44 \\
\hline 1997 & 1,56 \\
\hline 1998 & 1,76 \\
\hline 1999 & 1,65 \\
\hline 2000 & 1,43 \\
\hline 2001 & 1,39 \\
\hline 2002 & 1,31 \\
\hline & \\
\hline
\end{tabular}


Tabela 3.11 - Número de não-aprovados corrigido

\begin{tabular}{|c|c|c|c|c|c|c|c|c|c|c|c|}
\hline & $1^{\text {" série }}$ & $2^{a}$ série & $3^{a}$ série & $4^{2}$ série & $5^{2}$ série & $6^{2}$ série & $7^{a}$ série & $8^{4}$ série & $9^{a}$ série & $10^{x}$ série & $11^{2}$ série \\
\hline 1981 & 4.065 .540 & .098 .013 & 772.474 & 534.142 & 915.714 & 576.937 & 420.176 & 253.158 & 497.017 & 247.517 & 87.994 \\
\hline 1982 & 4.419 .803 & 1.229 .192 & 867.816 & 609.330 & 1.072 .983 & & & & & & 112.300 \\
\hline 1983 & 4.363 .767 & 1.284 .517 & 916.471 & 655.750 & 1.125 .304 & 704.433 & & & & & \\
\hline 1984 & 4.258 .194 & 1.390 .638 & 949.817 & 687.071 & 1.224.358 & 749.221 & 520.109 & & 599.943 & & 111.341 \\
\hline 1985 & 3.638 .568 & 1.625 .275 & 985.568 & 720.768 & 1.224 .692 & 736.499 & 501.748 & 292.339 & 607.873 & 297.525 & 100.803 \\
\hline 1986 & 3.495 .483 & 1.807.080 & 1.091 .661 & 767.600 & 1.341 .479 & & & & 640.379 & & \\
\hline 1987 & 3.389.945 & 1.852 .671 & 1.112 .152 & & & & & & & & \\
\hline 1988 & 3.611 .232 & 1.897 .584 & 1.166 .867 & 829.084 & 1.416 .659 & & 547.760 & & 682.226 & 330.211 & 114.057 \\
\hline 1989 & 3.424 .437 & 1.844 .605 & 1.148 .691 & 805.540 & & & & & & & \\
\hline 1990 & 3.206 .348 & 1.857 .392 & 1.159 .9 & 849.7 & 1.577. & & & & & & \\
\hline 1991 & 3.143 .945 & 1.907 .877 & 1.162 .02 & 843.812 & & & & & & & 2.023 \\
\hline 1992 & & & & & & & & & & & 139.314 \\
\hline 1993 & & & & & & & & & & & \\
\hline 1994 & 3.07 & & & & & & & & & & \\
\hline 1995 & 3.003 .875 & 1.749 .255 & 1.121 .760 & 831.144 & 1.610 .756 & 1.076 .465 & .477 & & .778 & 1.372 & 192.738 \\
\hline 1996 & 2.641 .504 & 1.473 .863 & 1.006 .422 & 725.781 & 1.507 .492 & 972.498 & 677.482 & 419.233 & 885.293 & 407.775 & 138.228 \\
\hline 1997 & 2.685 .854 & 1.287 .038 & 879.285 & & & & & & & & 159.789 \\
\hline 1998 & 2.919 .795 & 1.154 .079 & 818.230 & 623.172 & 1.200 .150 & 765.283 & 564.782 & 364.502 & 768.088 & 415.131 & 176.753 \\
\hline 1999 & 2.726 .717 & 1.203 .813 & 862.650 & 657.205 & 1.270 .831 & 792.461 & 732.955 & 431.9 & 957.077 & 484.272 & 176.958 \\
\hline 2000 & 2.182 .396 & 1.189 .378 & 968.816 & & & & & & 1.071 .893 & & 270.774 \\
\hline 2001 & 1.816 .842 & 1.008 .135 & 863.594 & 642.152 & 1.309 .226 & 753.993 & 773.514 & 466.444 & 1.156 .033 & 435.522 & 323.018 \\
\hline
\end{tabular}

Tabela 3.12 - Repetência mínima

\begin{tabular}{|c|c|c|c|c|c|c|c|c|c|c|c|}
\hline & série & série & $3^{n}$ série & $4^{\prime \prime}$ série & $5^{2}$ ses & $6^{6}$ serie & serie & $8^{\circ}$ série & $g^{a}$ série & $10^{\circ}$ série & $11^{\circ}$ série \\
\hline 1981 & 119.941 & 973.635 & 158.365 & 281.507 & 512.392 & 367.443 & 267.643 & 162.220 & 282.938 & 152.138 & 42.167 \\
\hline 1982 & 162.693 & 1.099 .134 & & & & & & & & & \\
\hline 1983 & .215 .694 & & & & & & & & & & \\
\hline 1984 & .456 .890 & 1.253 .939 & 539.600 & 374.661 & 667.3 & & & & & & \\
\hline 1985 & & 1.490 .592 & & & & & & & & & \\
\hline 1986 & $2.948 .18 \mathrm{~g}$ & 1.671 .916 & & & & & & & & & \\
\hline 1987 & & 1.716 .169 & & & & & & & & & \\
\hline 1988 & 3.163 .884 & 1.756 .324 & 792.842 & & & & & & & & \\
\hline 1989 & & & & & & & & & & & \\
\hline 1990 & & 1.7 & & & & & & & & & \\
\hline 1991 & & 1.822 & & & & & & & & & \\
\hline 1992 & 2.974 .109 & 1.857 & 908.1 & 607. & 1.14 & & & & & & 83.571 \\
\hline 1993 & & & & & & & & & & & \\
\hline 198 & & & & & & & & & & & \\
\hline 1995 & & & & & & & & & & & \\
\hline 1996 & 3.208 .534 & 1.389 .539 & 864.161 & 569.284 & 1.107 .520 & 660.251 & 410.777 & 279.946 & 611.981 & 263.436 & 102.529 \\
\hline 1997 & & & & & & & & & & & \\
\hline 199 & & & & & & & & & & & \\
\hline 1999 & & & & & & & & & & & 110.827 \\
\hline 2000 & 2.281 .813 & 1.109 .856 & 691.599 & 485.926 & 998.718 & 463.724 & 370.917 & 381.242 & 501.168 & 18B.501 & 139.314 \\
\hline 2001 & 1.972 .103 & 932.301 & 660.195 & 499.755 & 969.831 & 446.939 & 385.448 & 389.337 & 472.584 & 243.838 & 153.042 \\
\hline
\end{tabular}


Tabela 3.13 - Proporção mínima de não-aprovados que retornam à mesma série no ano seguinte (corresponde a $p=0$ )

\begin{tabular}{|l|l|l|l|l|l|l|l|l|l|l|}
\hline & $2^{a}$ série & $3^{a}$ série & $4^{a}$ série & $5^{a}$ série & $6^{a}$ série & $7^{a}$ série & $8^{a}$ série & $9^{a}$ série & $10^{a}$ séri e & $11^{a}$ sórie \\
\hline 1981 & 0,887 & 0,593 & 0,527 & 0,560 & 0,637 & 0,637 & 0,641 & 0,569 & 0,615 & 0,479 \\
\hline 1982 & 0,894 & 0,573 & 0,538 & 0,527 & 0,634 & 0,652 & 0,696 & 0,569 & 0,660 & 0,482 \\
\hline 1983 & 0,897 & 0,591 & 0,538 & 0,557 & 0,618 & 0,570 & 0,538 & 0,548 & 0,721 & 0,468 \\
\hline 1984 & 0,902 & 0,568 & 0,545 & 0,545 & 0,611 & 0,582 & 0,590 & 0,575 & 0,658 & 0,505 \\
\hline 1985 & 0,917 & 0,639 & 0,579 & 0,627 & 0,635 & 0,603 & 0,597 & 0,614 & 0,712 & 0,660 \\
\hline 1986 & 0,925 & 0,655 & 0,602 & 0,584 & 0,598 & 0,566 & 0,573 & 0,594 & 0,638 & 0,488 \\
\hline 1987 & 0,926 & 0,681 & 0,626 & 0,628 & 0,646 & 0,637 & 0,682 & 0,703 & 0,733 & 0,593 \\
\hline 1988 & 0,926 & 0,679 & 0,662 & 0,663 & 0,655 & 0,616 & 0,645 & 0,660 & 0,655 & 0,553 \\
\hline 1989 & 0,923 & 0,711 & 0,699 & 0,684 & 0,676 & 0,655 & 0,680 & 0,670 & 0,649 & 0,551 \\
\hline 1990 & 0,954 & 0,725 & 0,679 & 0,680 & 0,682 & 0,661 & 0,668 & 0,650 & 0,633 & 0,579 \\
\hline 1991 & 0,955 & 0,727 & 0,679 & 0,697 & 0,684 & 0,647 & 0,673 & 0,684 & 0,794 & 0,553 \\
\hline 1992 & 0,956 & 0,744 & 0,687 & 0,706 & 0,685 & 0,639 & 0,678 & 0,663 & 0,895 & 0,600 \\
\hline 1993 & 0,956 & 0,797 & 0,697 & 0,701 & 0,695 & 0,645 & 0,719 & 0,713 & 0,681 & 0,597 \\
\hline 1994 & 0,952 & 0,828 & 0,747 & 0,751 & 0,728 & 0,664 & 0,766 & 0,641 & 0,668 & 0,666 \\
\hline 1995 & 0,951 & 0,811 & 0,715 & 0,740 & 0,677 & 0,636 & 0,661 & 0,616 & 0,586 & 0,565 \\
\hline 1996 & 0,943 & 0,859 & 0,784 & 0,735 & 0,679 & 0,606 & 0,668 & 0,691 & 0,646 & 0,742 \\
\hline 1997 & 0,934 & 0,855 & 0,749 & 0,786 & 0,612 & 0,607 & 0,754 & 0,648 & 0,455 & 0,457 \\
\hline 1998 & 0,925 & 0,754 & 0,612 & 0,720 & 0,524 & 0,569 & 0,616 & 0,713 & 0,530 & 0,569 \\
\hline 1999 & 0,928 & 0,687 & 0,615 & 0,740 & 0,537 & 0,503 & 0,799 & 0,586 & 0,483 & 0,626 \\
\hline 2000 & 0,933 & 0,714 & 0,691 & 0,753 & 0,549 & 0,446 & 0,840 & 0,468 & 0,331 & 0,515 \\
\hline 2001 & 0,925 & 0,764 & 0,778 & 0,741 & 0,593 & 0,498 & 0,835 & 0,409 & 0,560 & 0,474 \\
\hline
\end{tabular}

Tabela 3.14 - Proporção de não-aprovados que retornam à mesma série no ano seguinte, com $p=0,4$

\begin{tabular}{|c|c|c|c|c|c|c|c|c|c|c|}
\hline & $2^{*}$ sèrie & $3^{*}$ série & $4^{2}$ série & $5^{*}$ série & $6^{2}$ série & $7^{2}$ série & $8^{a}$ série & $9^{a}$ série & $10^{\mathrm{a}}$ série & $11^{\text {a }}$ série \\
\hline 1981 & 0,932 & 0,756 & 0,716 & 0,736 & 0,782 & 0,782 & 0,784 & 0,742 & 0,769 & 0,688 \\
\hline 1982 & 0,937 & 0,744 & 0,723 & 0,716 & 0,781 & 0,791 & 0,818 & 0,741 & 0,796 & 0,689 \\
\hline 1983 & 0,938 & 0,755 & 0,723 & 0,734 & 0,771 & 0.742 & 0.723 & 0,729 & 0.833 & 0.681 \\
\hline 1984 & 0,941 & 0,741 & 0,727 & 0,727 & 0,766 & 0,749 & 0,754 & 0,745 & 0.795 & 0,703 \\
\hline 1985 & 0,950 & 0,783 & 0,747 & 0,776 & 0,781 & 0,762 & 0,758 & 0,768 & 0,827 & 0,796 \\
\hline 1986 & 0.955 & 0.793 & 0.761 & 0.750 & 0.759 & 0.740 & 0.744 & 0.757 & 0.783 & 0.693 \\
\hline 1987 & 0,956 & 0,808 & 0,776 & 0,777 & 0,788 & 0,782 & 0,809 & 0,822 & 0,840 & 0,756 \\
\hline $198 B$ & 0,955 & 0,808 & 0,797 & 0,798 & 0,793 & 0,769 & 0,787 & 0,796 & 0,793 & 0,732 \\
\hline 1989 & 0,954 & 0,827 & 0,819 & 0,811 & 0,806 & 0,793 & 0,808 & 0,802 & 0,789 & 0,730 \\
\hline 1990 & 0,973 & 0,835 & 0,807 & 0,808 & 0.809 & 0,797 & 0,801 & 0,790 & 0,780 & 0,747 \\
\hline 1991 & 0,973 & 0,836 & 0,808 & 0,818 & 0,811 & 0,788 & 0,804 & 0,811 & 0,877 & 0,732 \\
\hline 1992 & 0,974 & 0,847 & 0,812 & 0,823 & 0.811 & 0,783 & 0,807 & 0,798 & 0,937 & 0,760 \\
\hline 1993 & 0,973 & 0,878 & 0,818 & 0,820 & 0,817 & 0,787 & 0,831 & 0,828 & 0,809 & 0,758 \\
\hline 1994 & 0,971 & 0,897 & 0,848 & 0,851 & 0,837 & 0,798 & 0,860 & 0,785 & 0,801 & 0,800 \\
\hline 1995 & 0,971 & 0,887 & 0,829 & 0,844 & 0,806 & 0,781 & 0,797 & 0,770 & 0,751 & 0,739 \\
\hline 1996 & 0,966 & 0,915 & 0,871 & 0.841 & 0.807 & 0,764 & 0,801 & 0,815 & 0,788 & 0,845 \\
\hline 1997 & 0,961 & 0,913 & 0,849 & 0,872 & 0,767 & 0,764 & 0,852 & 0,789 & 0,673 & 0,674 \\
\hline 1998 & 0,955 & 0,852 & 0,767 & 0,832 & 0,714 & 0,741 & 0,769 & 0,828 & 0,718 & 0,741 \\
\hline 1999 & 0,957 & 0,812 & 0,769 & 0,844 & 0,722 & 0,702 & 0,879 & 0,752 & 0,690 & 0,776 \\
\hline 2000 & 0,960 & 0,828 & 0,814 & 0,852 & 0,729 & 0,667 & 0,904 & 0,681 & 0,599 & 0,709 \\
\hline 2001 & 0,955 & 0,859 & 0,867 & 0,844 & 0,756 & 0,699 & 0,901 & 0,645 & 0,736 & 0,684 \\
\hline
\end{tabular}


Tabela 3.15 - Proporção de não-aprovados que retornam à mesma série no ano seguinte, $\operatorname{com} p=0,6$

\begin{tabular}{|l|l|l|l|l|l|l|l|l|l|l|}
\hline & $2^{*}$ série & $3^{*}$ série & $4^{*}$ série & $5^{*}$ série & $6^{*}$ série & $7^{*}$ série & $8^{*}$ série & $9^{a}$ série & $10^{*}$ série & $1^{4}$ série \\
\hline 1981 & 0,955 & 0,837 & 0,811 & 0,824 & 0,855 & 0,855 & 0,856 & 0,828 & 0,846 & 0,792 \\
\hline 1982 & 0,958 & 0,829 & 0,815 & 0,811 & 0,854 & 0,861 & 0,878 & 0,827 & 0,864 & 0,793 \\
\hline 1983 & 0,959 & 0,837 & 0,815 & 0,823 & 0,847 & 0,828 & 0,815 & 0,819 & $0,88 B$ & 0,787 \\
\hline 1984 & 0,961 & 0,827 & 0,818 & 0,818 & 0,844 & 0,833 & 0,836 & 0,830 & 0,863 & 0,802 \\
\hline 1985 & 0,967 & 0,856 & 0,832 & 0,851 & 0,854 & 0,841 & 0,839 & 0,846 & 0,885 & 0,864 \\
\hline 1986 & 0,970 & 0,862 & 0,841 & 0,834 & 0,839 & 0,826 & 0,829 & 0,838 & 0,855 & 0,795 \\
\hline 1987 & 0,971 & 0,872 & 0,851 & 0,851 & 0,859 & 0,855 & 0,873 & 0,881 & 0,893 & 0,837 \\
\hline 1988 & 0,970 & 0,872 & 0,865 & 0,865 & 0,862 & 0,846 & 0,858 & 0,864 & 0,862 & 0,821 \\
\hline 1989 & 0,969 & 0,884 & 0,879 & 0,874 & 0,870 & 0,862 & 0,872 & 0,868 & 0,859 & 0,820 \\
\hline 1990 & 0,982 & 0,890 & 0,872 & 0,872 & 0,873 & 0,864 & 0,867 & 0,860 & 0,853 & 0,832 \\
\hline 1991 & 0,982 & 0,891 & 0,872 & 0,879 & 0,874 & 0,859 & 0,869 & 0,874 & 0,918 & 0,821 \\
\hline 1992 & 0,983 & 0,898 & 0,875 & 0,882 & 0,874 & 0,855 & 0,871 & 0,865 & 0,958 & 0,840 \\
\hline 1993 & 0,982 & 0,919 & 0,879 & 0,880 & 0,878 & 0,858 & 0,888 & 0,885 & 0,873 & 0,839 \\
\hline 1994 & 0,981 & 0,931 & 0,899 & 0,901 & 0,892 & 0,866 & 0,906 & 0,856 & 0,867 & 0,866 \\
\hline 1995 & 0,980 & 0,925 & 0,886 & 0,896 & 0,871 & 0,854 & 0,865 & 0,846 & 0,834 & 0,826 \\
\hline 1996 & 0,977 & 0,943 & 0,914 & 0,894 & 0,872 & 0,843 & 0,867 & 0,877 & 0,858 & 0,897 \\
\hline 1997 & 0,974 & 0,942 & 0,900 & 0,915 & 0,845 & 0,843 & 0,902 & 0,859 & 0,782 & 0,783 \\
\hline 1998 & 0,970 & 0,902 & 0,845 & 0,888 & 0,809 & 0,828 & 0,846 & 0,885 & 0,812 & 0,827 \\
\hline 1999 & 0,971 & 0,875 & 0,846 & 0,896 & 0,815 & 0,801 & 0,920 & 0,835 & 0,793 & 0,851 \\
\hline 2000 & 0,973 & 0,886 & 0,876 & 0,901 & 0,819 & 0,778 & 0,936 & 0,787 & 0,732 & 0,806 \\
\hline 2001 & 0,970 & 0,906 & 0,911 & 0,896 & 0,837 & 0,799 & 0,934 & 0,764 & 0,824 & 0,790 \\
\hline
\end{tabular}

Tabela 3.16 - Proporção de não aprovados que retornam à mesma série no ano seguinte, $\operatorname{com} p=0,8$

\begin{tabular}{|c|c|c|c|c|c|c|c|c|c|c|}
\hline & $2^{*}$ sêrie & $3^{2}$ sêrie & $4^{2}$ série & $5^{*}$ setrie & $6^{*}$ série & $7^{2}$ série & $8^{a}$ série & $9^{a}$ série & $10^{\mathrm{a}}$ série & $11^{a}$ série \\
\hline 1981 & 0,98 & 0,92 & 0,91 & 0,91 & 0,93 & 0,93 & 0,93 & 0,91 & 0,92 & 0,90 \\
\hline 1982 & 0,98 & 0,92 & 0,91 & 0,91 & 0,93 & 0,93 & 0,94 & 0,91 & 0,93 & 0,90 \\
\hline 1983 & 0,98 & 0,92 & 0,91 & 0,91 & 0,92 & 0,91 & 0,91 & 0,91 & 0,94 & 0,89 \\
\hline 1984 & 0,98 & 0,91 & 0,91 & 0,91 & 0,92 & 0,92 & 0,92 & 0,92 & 0,93 & 0,90 \\
\hline 1985 & 0,98 & 0,93 & 0,92 & 0,93 & 0,93 & 0,92 & 0,92 & 0,92 & 0,94 & 0,93 \\
\hline 1986 & 0.99 & 0.93 & 0.92 & 0.92 & 0,92 & 0,91 & 0,92 & 0,92 & 0.93 & 0,90 \\
\hline 1987 & 0,99 & 0,94 & 0,93 & 0,93 & 0,93 & 0,93 & 0,94 & 0,94 & 0,95 & 0,92 \\
\hline 1988 & 0,99 & 0,94 & 0,93 & 0,93 & 0.93 & 0,92 & 0,93 & 0,93 & 0,93 & 0,91 \\
\hline 1989 & 0,99 & 0,94 & 0,94 & 0,94 & 0,84 & 0,93 & 0,94 & 0,93 & 0,93 & 0,91 \\
\hline 1990 & 0,99 & 0,95 & 0,94 & 0,84 & 0,84 & 0,93 & 0,93 & 0,93 & 0,93 & 0,92 \\
\hline 1991 & 0,99 & 0,95 & 0,94 & 0,94 & 0,94 & 0,93 & 0,94 & 0,94 & 0,96 & 0,91 \\
\hline 1992 & 0,99 & 0,95 & 0,94 & 0,94 & 0,94 & 0,93 & 0,94 & 0,93 & 0,98 & 0,92 \\
\hline 1993 & 0,99 & 0,96 & 0,94 & 0,94 & 0,94 & 0,93 & 0,94 & 0,94 & 0,94 & 0,92 \\
\hline 1994 & 0,99 & 0,97 & 0,95 & 0,25 & 0,25 & 0,93 & 0,95 & 0,29 & 0,23 & 0,93 \\
\hline 1995 & 0,99 & 0,96 & 0,94 & 0,95 & 0,94 & 0,93 & 0,93 & 0,92 & 0,92 & 0,91 \\
\hline 1996 & 0,99 & 0,97 & 0,96 & 0,85 & 0,84 & 0,92 & 0,93 & 0,84 & 0,93 & 0,95 \\
\hline 1997 & 0,99 & 0,97 & 0,95 & 0,96 & 0,92 & 0,92 & 0,95 & 0,93 & 0,89 & 0,89 \\
\hline 1998 & 0,99 & 0,95 & 0,92 & 0,94 & 0,91 & 0,91 & 0,92 & 0,94 & 0,91 & 0,91 \\
\hline 1999 & 0,99 & 0,94 & 0,92 & 0,95 & 0,91 & 0,90 & 0,96 & 0,92 & 0,90 & 0,93 \\
\hline 2000 & 0,99 & 0,94 & 0,94 & 0,95 & 0,91 & 0,89 & 0,97 & 0,89 & 0,87 & 0,90 \\
\hline 2001 & 0,99 & 0,95 & 0,96 & 0,95 & 0,92 & 0,90 & 0,97 & 0,88 & 0,91 & 0,90 \\
\hline
\end{tabular}


Tabela 3.17 - Proporção mínima de aprovados que retornam à série seguinte no ano seguinte (corresponde a $p=1$ )

\begin{tabular}{|c|c|c|c|c|c|c|c|c|c|c|}
\hline & $2^{*}$ sêrie & $3^{2}$ série & $4^{*}$ série & $5^{*}$ sêrie & $6^{2}$ série & $7^{2}$ série & $8^{a}$ série & g" série & $10^{\mathrm{a}}$ série & $11^{a}$ série \\
\hline 1981 & 0,956 & 0,879 & 0,885 & 0,786 & 0,850 & 0,864 & 0,904 & 0,748 & 0,866 & 0,928 \\
\hline 1982 & 0,953 & 0,859 & 0,874 & 0,735 & 0,833 & 0.860 & 0,910 & 0,730 & 0,870 & 0,907 \\
\hline 1983 & 0,955 & 0,860 & 0,866 & 0,743 & 0,816 & 0.812 & 0.845 & 0.697 & 0.886 & 0,907 \\
\hline 1984 & 0,957 & 0,852 & 0,864 & 0,716 & 0,800 & 0.818 & 0.875 & 0,706 & 0,845 & 0,909 \\
\hline 1985 & 0,957 & 0,875 & 0,872 & 0,772 & 0,823 & 0,837 & 0,885 & 0.739 & 0.880 & 0,944 \\
\hline 1986 & 0,955 & 0,868 & 0,875 & 0,730 & 0,789 & 0,803 & 0,863 & 0,712 & 0,849 & 0,917 \\
\hline 1987 & 0,956 & 0,878 & 0,884 & 0,769 & 0,827 & 0.850 & 0,907 & 0,792 & 0,891 & 0,934 \\
\hline 1988 & 0,955 & 0,876 & 0,890 & 0,784 & 0,837 & 0.847 & 0,899 & 0.757 & 0,857 & 0,926 \\
\hline 1989 & 0,958 & 0,894 & 0,910 & 0,802 & 0,845 & 0,864 & 0,910 & 0,767 & 0,851 & 0,916 \\
\hline 1990 & 0.975 & 0.903 & 0.904 & 0.795 & 0.844 & 0.862 & 0.901 & 0,744 & 0.839 & 0,918 \\
\hline 1991 & 0.975 & 0.906 & 0.910 & 0.817 & 0.860 & 0.867 & 0.911 & 0,780 & 0,923 & 0,929 \\
\hline 1992 & 0.974 & 0.906 & 0.910 & 0.826 & 0.866 & 0.872 & 0.919 & 0.761 & 0,960 & 0,933 \\
\hline 1993 & 0,974 & 0,927 & 0.915 & 0,831 & 0,878 & 0,888 & 0.939 & 0.833 & 0,904 & 0,950 \\
\hline 1994 & 0.976 & 0.944 & 0.937 & 0.871 & 0.897 & 0.902 & 0.955 & 0.802 & 0.890 & 0.952 \\
\hline 1995 & 0,976 & 0,940 & 0.928 & 0.861 & 0.871 & 0.887 & 0.924 & 0,784 & 0.857 & 0,927 \\
\hline 1996 & 0.977 & 0.963 & 0.955 & 0.875 & 0.892 & 0.894 & 0.937 & 0.858 & 0.912 & 0,973 \\
\hline 1997 & 0,978 & 0,967 & 0,957 & 0,921 & 0,900 & 0,918 & 0,962 & 0,863 & 0,887 & 0,944 \\
\hline 1998 & 0,979 & 0.950 & 0.937 & 0,911 & 0,895 & 0,921 & 0.847 & 0,908 & 0,909 & 0,956 \\
\hline 1999 & 0,978 & 0,934 & 0,934 & 0,910 & 0,896 & 0,884 & 0,968 & 0,841 & 0,888 & 0,966 \\
\hline 2000 & 0,978 & 0,928 & 0.943 & 0,909 & 0,889 & 0,855 & 0,974 & 0,787 & 0,829 & 0,933 \\
\hline 2001 & 0,990 & 0,946 & 0,962 & 0,908 & 0,911 & 0,879 & 0,973 & 0,752 & 0,916 & 0,917 \\
\hline
\end{tabular}

Tabela 3.18 - Proporção de aprovados que retornam à série seguinte no ano seguinte, $\operatorname{com} p=0,8$

\begin{tabular}{|c|c|c|c|c|c|c|c|c|c|c|}
\hline & $2^{4}$ série & $3^{4}$ setrie & $4^{*}$ série & $5^{*}$ série & $6^{2}$ série & $7^{\prime \prime}$ série & $8^{a}$ série & $9^{a}$ série & $10^{\mathrm{a}}$ série & $11^{a}$ série \\
\hline 1981 & 0,965 & 0,903 & 0,908 & 0,829 & 0,880 & 0,891 & 0,924 & 0,798 & 0,893 & 0,942 \\
\hline 1982 & 0,963 & 0,887 & 0,899 & 0,788 & 0,867 & 0,888 & 0,928 & 0,784 & 0.896 & 0,925 \\
\hline 1983 & 0,964 & 0,888 & 0,893 & 0,794 & 0,853 & 0,850 & 0,876 & 0,758 & 0,909 & 0,925 \\
\hline 1984 & 0,965 & 0,882 & 0,892 & 0,773 & 0,840 & 0,854 & 0,900 & 0,765 & 0,876 & 0,927 \\
\hline 1985 & 0,965 & 0,900 & 0,898 & 0,817 & 0,859 & 0,870 & 0,908 & 0,791 & 0.904 & 0,955 \\
\hline 1986 & 0.964 & 0.895 & 0.900 & 0.784 & 0,831 & 0,843 & 0,890 & 0,770 & 0,879 & 0,934 \\
\hline 1987 & 0,965 & 0,902 & 0,907 & 0,815 & 0,862 & 0,880 & 0,926 & 0,833 & 0,913 & 0,947 \\
\hline 1988 & 0,964 & 0,900 & 0,912 & 0,827 & 0,870 & 0,877 & 0,919 & 0,806 & 0.886 & 0,941 \\
\hline 1989 & 0,966 & 0,916 & 0,928 & 0,841 & 0,876 & 0,891 & 0,928 & 0,814 & 0,881 & 0,933 \\
\hline 1990 & 0,980 & 0,922 & 0,924 & 0,836 & 0,875 & 0,890 & 0,921 & 0,795 & 0,871 & 0,934 \\
\hline 1991 & 0,980 & 0,925 & 0,928 & 0,854 & 0,888 & 0,894 & 0,929 & 0,824 & 0,938 & 0,944 \\
\hline 1992 & 0.979 & 0.925 & 0.928 & 0,861 & 0,892 & 0,898 & 0.935 & 0,809 & 0.968 & 0.947 \\
\hline 1993 & 0,979 & 0,942 & 0,932 & 0,865 & 0,903 & 0,911 & 0,951 & 0,867 & 0,923 & 0,960 \\
\hline 1994 & 0,981 & 0,255 & 0,950 & 0,897 & 0,918 & 0,922 & 0,964 & 0,841 & 0,912 & 0,962 \\
\hline 1995 & 0,981 & 0,952 & 0,942 & 0,889 & 0,896 & 0,910 & 0,939 & 0,827 & 0,886 & 0,941 \\
\hline 1996 & 0,982 & 0,970 & 0,964 & 0,900 & 0,914 & 0,915 & 0,949 & 0,886 & 0,930 & 0,978 \\
\hline 1997 & 0,983 & 0,974 & 0,966 & 0,937 & 0,920 & 0,935 & 0,969 & 0,891 & 0,910 & 0,956 \\
\hline 1998 & 0,983 & 0,960 & 0,950 & 0,929 & 0,916 & 0,937 & 0,958 & 0,926 & 0,927 & 0,965 \\
\hline 1999 & 0,982 & 0,947 & 0,947 & 0,928 & 0,917 & 0,907 & 0,974 & 0,873 & 0,911 & 0,973 \\
\hline 2000 & 0,982 & 0,943 & 0,954 & 0,927 & 0,911 & 0,884 & 0,979 & 0,830 & 0,864 & 0,946 \\
\hline 2001 & 0,984 & 0,957 & 0,970 & 0,927 & 0,929 & 0,903 & 0,978 & 0,802 & 0,933 & 0,933 \\
\hline
\end{tabular}


Tabela 3.19 - Proporção de aprovados que retornam à série seguinte, $\operatorname{com} p=0,6$

\begin{tabular}{|l|l|l|l|l|l|l|l|l|l|l|}
\hline & $2^{*}$ série & $3^{*}$ série & $4^{*}$ série & $5^{*}$ série & $6^{*}$ série & $7^{*}$ série & $8^{*}$ série & $9^{*}$ série & $10^{a}$ série & $1^{4}$ série \\
\hline 1981 & 0,974 & 0,927 & 0,931 & 0,872 & 0,910 & 0,919 & 0,943 & 0,849 & 0,920 & 0,957 \\
\hline 1982 & 0,972 & 0,916 & 0,924 & 0,841 & 0,900 & 0,916 & 0,946 & 0,838 & 0,922 & 0,944 \\
\hline 1983 & 0,973 & 0,916 & 0,919 & 0,846 & 0,890 & 0,887 & 0,907 & 0,818 & 0,932 & 0,944 \\
\hline 1984 & 0,974 & 0,911 & 0,919 & 0,830 & 0,880 & 0,891 & 0,925 & 0,824 & 0,907 & 0,946 \\
\hline 1985 & 0,974 & 0,925 & 0,923 & 0,863 & 0,894 & 0,902 & 0,931 & 0,843 & 0,928 & 0,966 \\
\hline 1986 & 0,973 & 0,921 & 0,925 & 0,838 & 0,874 & 0,882 & 0,918 & 0,827 & 0,909 & 0,950 \\
\hline 1987 & 0,974 & 0,927 & 0,931 & 0,861 & 0,896 & 0,910 & 0,944 & 0,875 & 0,935 & 0,960 \\
\hline 1988 & 0,973 & 0,925 & 0,934 & 0,871 & 0,902 & 0,908 & 0,939 & 0,854 & 0,914 & 0,956 \\
\hline 1989 & 0,975 & 0,937 & 0,946 & 0,881 & 0,907 & 0,919 & 0,946 & 0,860 & 0,911 & 0,950 \\
\hline 1990 & 0,985 & 0,942 & 0,943 & 0,877 & 0,907 & 0,917 & 0,941 & 0,947 & 0,903 & 0,951 \\
\hline 1991 & 0,985 & 0,944 & 0,946 & 0,890 & 0,916 & 0,920 & 0,947 & 0,868 & 0,954 & 0,958 \\
\hline 1992 & 0,985 & 0,943 & 0,946 & 0,896 & 0,919 & 0,923 & 0,951 & 0,857 & 0,976 & 0,960 \\
\hline 1993 & 0,985 & 0,956 & 0,949 & 0,899 & 0,927 & 0,933 & 0,963 & 0,900 & 0,942 & 0,970 \\
\hline 1994 & 0,986 & 0,966 & 0,962 & 0,923 & 0,938 & 0,941 & 0,973 & 0,881 & 0,934 & 0,971 \\
\hline 1995 & 0,985 & 0,964 & 0,957 & 0,917 & 0,922 & 0,932 & 0,954 & 0,870 & 0,914 & 0,956 \\
\hline 1996 & 0,986 & 0,978 & 0,973 & 0,925 & 0,935 & 0,936 & 0,962 & 0,915 & 0,947 & 0,984 \\
\hline 1997 & 0,987 & 0,980 & 0,974 & 0,953 & 0,940 & 0,951 & 0,977 & 0,918 & 0,932 & 0,967 \\
\hline 1998 & 0,987 & 0,970 & 0,962 & 0,947 & 0,937 & 0,952 & 0,968 & 0,945 & 0,945 & 0,974 \\
\hline 1999 & 0,987 & 0,961 & 0,961 & 0,946 & 0,938 & 0,930 & 0,981 & 0,905 & 0,933 & 0,979 \\
\hline 2000 & 0,987 & 0,957 & 0,966 & 0,946 & 0,933 & 0,913 & 0,984 & 0,872 & 0,898 & 0,960 \\
\hline 2001 & 0,988 & 0,968 & 0,977 & 0,945 & 0,947 & 0,927 & 0,994 & 0,851 & 0,950 & 0,950 \\
\hline
\end{tabular}

Tabela 3.20 - Proporção de aprovados que retornam à série seguinte no ano seguinte, $\operatorname{com} p=0,4$

\begin{tabular}{|c|c|c|c|c|c|c|c|c|c|c|}
\hline & $2^{2}$ setrie & $3^{*}$ série & $4^{*}$ série & $5^{*}$ setrie & $6^{2}$ série & $7^{2}$ série & $8^{a}$ série & $g^{a}$ série & $10^{A}$ série & $11^{a}$ série \\
\hline 1981 & 0,982 & 0,952 & 0,954 & 0,914 & 0,940 & 0,946 & 0,962 & 0,899 & 0,946 & 0,971 \\
\hline 1982 & 0,981 & 0,944 & 0,950 & 0,894 & 0,933 & 0,944 & 0,964 & 0,892 & 0,948 & 0,963 \\
\hline 1983 & 0,982 & 0,944 & 0,946 & 0,897 & 0,926 & 0,925 & 0,938 & 0,879 & 0,954 & 0,963 \\
\hline 1984 & 0,983 & 0,941 & 0,946 & 0,886 & 0,920 & 0,927 & 0,950 & 0,882 & 0,938 & 0,964 \\
\hline 1985 & 0,983 & 0,950 & 0,949 & 0,909 & 0,929 & 0,935 & 0,954 & 0,895 & 0,952 & 0,977 \\
\hline 1986 & 0,982 & 0,947 & 0,950 & 0.892 & 0,916 & 0,921 & 0,945 & 0,885 & 0,940 & 0,967 \\
\hline 1987 & 0,982 & 0,951 & 0,954 & 0,907 & 0,931 & 0,940 & 0,963 & 0,917 & 0,956 & 0,973 \\
\hline 1988 & 0,982 & 0,950 & 0,956 & 0,914 & 0,935 & 0,939 & 0,960 & 0,903 & 0,943 & 0,970 \\
\hline 1989 & 0,983 & 0,958 & 0,964 & 0,921 & 0,938 & 0,946 & 0,964 & 0,907 & 0,941 & 0,967 \\
\hline 1990 & 0,990 & 0,961 & 0,962 & 0,918 & 0,938 & 0,945 & 0,960 & 0,898 & 0,936 & 0,967 \\
\hline 1991 & 0,990 & 0,962 & 0,964 & 0,927 & 0,944 & 0,947 & 0,965 & 0,912 & 0,969 & 0,972 \\
\hline 1992 & 0,990 & 0,962 & 0,964 & 0,931 & 0,946 & 0,949 & 0,967 & 0,905 & 0,984 & 0.973 \\
\hline 1993 & 0,990 & 0,971 & 0,966 & 0,932 & 0,951 & 0,955 & 0,975 & 0,933 & 0,962 & 0,980 \\
\hline 1994 & 0,990 & 0,978 & 0,975 & 0,948 & 0,859 & 0,961 & 0,982 & 0,921 & 0,956 & 0,981 \\
\hline 1995 & 0,990 & 0,976 & 0,971 & 0,944 & 0,948 & 0,955 & 0,970 & 0,913 & 0,943 & 0,971 \\
\hline 1996 & 0,991 & 0,985 & 0,982 & 0,950 & 0,957 & 0,958 & 0,975 & 0,943 & 0,965 & 0,989 \\
\hline 1997 & 0,991 & 0,987 & 0,983 & 0,969 & 0,960 & 0,967 & 0,985 & 0,945 & 0,955 & 0,978 \\
\hline 1998 & 0,992 & 0,980 & 0,975 & 0,964 & 0,958 & 0,968 & 0,979 & 0,963 & 0,963 & 0.983 \\
\hline 1999 & 0,991 & 0,974 & 0,974 & 0,964 & 0,959 & 0,954 & 0,987 & 0,937 & 0,955 & 0,986 \\
\hline 2000 & 0,991 & 0,971 & 0,977 & 0,964 & 0,956 & 0,942 & 0,989 & 0,915 & 0,932 & 0,973 \\
\hline 2001 & 0,992 & 0,978 & 0,985 & 0,963 & 0,964 & 0,952 & 0,989 & 0,901 & 0,966 & 0,967 \\
\hline
\end{tabular}


Tabela 3.21 - Taxa de não-aprovação

\begin{tabular}{|c|c|c|c|c|c|c|c|c|c|c|c|}
\hline & $1^{2}$ série & $2^{2}$ série & $3^{2}$ série & $4^{2}$ série & $5^{a}$ série & 6" série & $7^{*}$ série & $8^{4}$ série & $9^{a}$ série & $10^{4}$ serrie & $11^{\prime \prime}$ série \\
\hline 1981 & 0,590 & 0,297 & 0,260 & 0,221 & 0,396 & 0,339 & 0,306 & 0,230 & 0,411 & 0,280 & 0,131 \\
\hline 1982 & 0,613 & 0,318 & 0,280 & 0,242 & 0,429 & 0,361 & 0,324 & 0,250 & 0,433 & 0,301 & 0,163 \\
\hline 1983 & 0,596 & 0,325 & 0,289 & 0,253 & 0,435 & 0,373 & 0,347 & 0,276 & 0,456 & 0,311 & 0,159 \\
\hline 1984 & 0,574 & 0,334 & 0,292 & 0,260 & 0,457 & 0,386 & 0,345 & 0,259 & 0,469 & 0,336 & 0,163 \\
\hline 1985 & 0,539 & 0,363 & 0,293 & 0,265 & 0,446 & 0,376 & 0,328 & 0,245 & 0,460 & 0,328 & 0,149 \\
\hline 1986 & 0.536 & 0.387 & 0.309 & 0.271 & 0,464 & 0.399 & 0.356 & 0.264 & 0.462 & 0.327 & 0.151 \\
\hline 1987 & 0,521 & 0,389 & 0,307 & 0,264 & 0,453 & 0,383 & 0.338 & 0,250 & 0,456 & 0,320 & 0,154 \\
\hline 1988 & 0,533 & 0,387 & 0,314 & 0,272 & 0,450 & 0,374 & 0,330 & 0,248 & 0,460 & 0,324 & 0,155 \\
\hline 1989 & 0,505 & 0,370 & 0,298 & 0,256 & 0,446 & 0,375 & 0.327 & 0,247 & 0,464 & 0,332 & 0,170 \\
\hline 1990 & 0,483 & 0,361 & 0,289 & 0.256 & 0,451 & 0,380 & 0,334 & 0,259 & 0,479 & 0,344 & 0,177 \\
\hline 1991 & 0,484 & 0,361 & 0,278 & 0,242 & 0,430 & 0,358 & 0,317 & 0,242 & 0,470 & 0,305 & 0,152 \\
\hline 1992 & 0,490 & 0,369 & 0,285 & 0,243 & 0,415 & 0,348 & 0,304 & 0,229 & 0,481 & 0,308 & 0,163 \\
\hline 1993 & 0,497 & 0,366 & 0,278 & 0,234 & 0,394 & 0,327 & 0,279 & 0,204 & 0,406 & 0,271 & 0,130 \\
\hline 1994 & 0,467 & 0,340 & 0,259 & 0,212 & 0,369 & 0,308 & 0.260 & 0,181 & 0,406 & 0,287 & 0,142 \\
\hline 1995 & 0,460 & 0,332 & 0,254 & 0.216 & 0,375 & 0,314 & 0.267 & 0,207 & 0.410 & 0,296 & 0,163 \\
\hline 1996 & 0.417 & 0.280 & 0,224 & 0,184 & 0,343 & 0,279 & 0.236 & 0,179 & 0,350 & 0,236 & 0,108 \\
\hline 1997 & 0,408 & 0,250 & 0,186 & 0,160 & 0,282 & 0,230 & 0,194 & 0,149 & 0.302 & 0,203 & 0,111 \\
\hline 1998 & 0.412 & 0.223 & 0,175 & 0,142 & 0,258 & 0,200 & 0,175 & 0,133 & 0.265 & 0,192 & 0,106 \\
\hline 1999 & 0,413 & 0,226 & 0,183 & 0,152 & 0,264 & 0,202 & 0,212 & 0,148 & 0,300 & 0,200 & 0,094 \\
\hline 2000 & 0,376 & 0,235 & 0,203 & 0,163 & 0,278 & 0,210 & 0,233 & 0,145 & 0,324 & 0,225 & 0,130 \\
\hline 2001 & 0,324 & 0,211 & 0,187 & 0,148 & 0,275 & 0,190 & 0,214 & 0,145 & 0,336 & 0,176 & 0,151 \\
\hline
\end{tabular}

Tabela 3.22 - Taxa de repetência mínima

\begin{tabular}{|c|c|c|c|c|c|c|c|c|c|c|c|}
\hline & $1^{*}$ série & $2^{2}$ série & $3^{2}$ série & $4^{a}$ série & $5^{a}$ série & $6^{a}$ série & $7^{*}$ série & $g^{a}$ série & $9^{n}$ série & $10^{\prime \prime}$ série & $11^{4}$ série \\
\hline 1981 & 0,597 & 0,264 & 0,154 & 0,116 & 0,221 & 0,216 & 0,195 & 0,147 & 0,234 & 0,172 & 0,063 \\
\hline 1982 & 0,577 & 0,285 & 0,160 & 0,130 & 0,226 & 0,229 & 0.211 & 0,174 & 0,246 & 0,199 & 0,079 \\
\hline 1983 & 0,576 & 0,291 & 0,171 & 0,136 & 0,242 & 0,231 & 0,198 & 0,148 & 0,250 & 0,224 & 0,074 \\
\hline 1984 & 0,466 & 0,301 & 0,166 & 0,142 & 0,249 & 0,236 & 0.201 & 0,153 & 0,270 & 0.221 & 0,082 \\
\hline 1985 & 0,463 & 0,333 & 0,187 & 0,154 & 0,280 & 0,239 & 0,198 & 0,147 & 0,282 & 0,234 & 0,099 \\
\hline 1986 & 0.452 & 0.358 & 0.202 & 0.163 & 0.271 & 0.238 & 0.201 & 0.151 & 0.275 & 0.209 & 0.074 \\
\hline 1987 & 0,486 & 0,360 & 0,209 & 0,166 & 0,284 & 0,247 & 0,215 & 0,170 & 0,321 & 0.235 & 0,091 \\
\hline 1988 & 0,467 & 0,358 & 0,213 & 0,180 & 0,298 & 0,245 & 0,203 & 0,160 & 0,304 & 0,212 & 0,085 \\
\hline 1989 & 0,456 & 0,341 & 0,212 & 0,179 & 0,305 & 0,254 & 0.214 & 0,168 & 0,311 & 0.216 & 0,094 \\
\hline 1990 & 0.452 & 0,345 & 0,209 & 0.174 & 0,307 & 0,259 & 0.221 & 0.173 & 0.311 & 0.218 & 0.103 \\
\hline 1991 & 0,447 & 0,345 & 0,202 & 0,165 & 0,300 & 0,245 & 0.205 & 0,163 & 0,322 & 0,243 & 0,084 \\
\hline 1992 & 0,463 & 0,353 & 0,212 & 0,167 & 0,293 & 0,238 & 0,194 & 0,155 & 0,319 & 0.276 & 0,098 \\
\hline 1993 & 0,477 & 0,350 & 0,221 & 0,163 & 0,276 & 0,227 & 0,180 & 0,147 & 0,289 & 0,184 & 0,078 \\
\hline 1984 & 0.456 & 0,324 & 0,214 & 0.159 & 0,277 & 0,225 & 0.173 & 0,139 & 0.260 & 0,191 & 0.095 \\
\hline 1995 & 0,443 & 0,316 & 0,206 & 0,154 & 0,278 & 0,213 & 0,170 & 0,137 & 0,253 & 0,173 & 0,092 \\
\hline 1996 & 0,507 & 0,264 & 0,192 & 0,145 & 0,252 & 0,189 & 0,143 & 0,120 & 0,242 & 0,153 & 0,080 \\
\hline 1997 & 0,585 & 0,233 & 0,159 & 0,120 & 0,222 & 0,141 & 0,118 & 0,112 & 0,195 & 0,093 & 0,051 \\
\hline 1998 & 0,473 & 0,206 & 0,132 & 0,087 & 0,186 & 0,105 & 0.100 & 0,082 & 0,189 & 0,102 & 0,060 \\
\hline 1999 & 0,378 & 0,210 & 0,126 & 0,094 & 0,196 & 0,108 & 0,107 & 0,118 & 0,176 & 0,097 & 0,059 \\
\hline 2000 & 0,394 & 0,220 & 0,145 & 0,113 & 0,210 & 0,115 & 0,104 & 0,122 & 0,152 & 0,074 & 0.067 \\
\hline 2001 & 0,352 & 0,195 & 0,143 & 0,115 & 0,204 & 0,113 & 0,106 & 0,121 & 0,137 & 0,098 & 0,072 \\
\hline
\end{tabular}


Tabela 3.23 - Taxa de repetência corrigida

\begin{tabular}{|c|c|c|c|c|c|c|c|c|c|c|c|}
\hline & $1^{2}$ série & $2^{a}$ série & $3^{2}$ série & $4^{2}$ série & $5^{a}$ série & $6^{a}$ série & $7^{*}$ série & $8^{a}$ série & $9^{n}$ série & $10^{2}$ série & $11^{*}$ série \\
\hline 1981 & 0,580 & 0,282 & 0,217 & 0,179 & 0,326 & 0,290 & 0,262 & 0,197 & 0,340 & 0,237 & 0,104 \\
\hline 1982 & 0,603 & 0,303 & 0,232 & 0,197 & 0,348 & 0,309 & 0,279 & 0,220 & 0,358 & 0,260 & 0,129 \\
\hline 1983 & 0,586 & 0,310 & 0,242 & 0,206 & 0,358 & 0,316 & 0,287 & 0,225 & 0,373 & 0.276 & 0.125 \\
\hline 1984 & 0,564 & 0,319 & 0.241 & 0,212 & 0,374 & 0,326 & 0,287 & 0.216 & 0,390 & 0.290 & 0.131 \\
\hline 1985 & 0,529 & 0,348 & 0,251 & 0,220 & 0,380 & 0,321 & 0,276 & 0,206 & 0,389 & 0,290 & 0,129 \\
\hline 1986 & 0,526 & 0,372 & 0.266 & 0,228 & 0,387 & 0,335 & 0,294 & 0,219 & 0,387 & 0,280 & 0,120 \\
\hline 1987 & 0,511 & 0,374 & 0,268 & 0,225 & 0,386 & 0,329 & 0,289 & 0,218 & 0,402 & 0,286 & 0,129 \\
\hline 1988 & 0,523 & 0,372 & 0,273 & 0,235 & 0,389 & 0.322 & 0,280 & 0.213 & 0,398 & 0.279 & 0,127 \\
\hline 1989 & 0,495 & 0.355 & 0.264 & 0,225 & 0,390 & 0.326 & 0.282 & 0.216 & 0,403 & 0.286 & 0,140 \\
\hline 1990 & 0,478 & 0,351 & 0.257 & 0,223 & 0,393 & 0,332 & 0,289 & 0.225 & 0,412 & 0,293 & 0,147 \\
\hline 1991 & 0,479 & 0,351 & 0,248 & 0,211 & 0,378 & 0,313 & 0,273 & 0,210 & 0,411 & 0,280 & 0.125 \\
\hline 1992 & 0,485 & 0,359 & 0,256 & 0,212 & 0,366 & 0,304 & 0,260 & 0,200 & 0,416 & 0,295 & 0,137 \\
\hline 1993 & 0,492 & 0,356 & 0,255 & 0,206 & 0,347 & 0,287 & 0,239 & 0,181 & 0,359 & 0,236 & 0,109 \\
\hline 1994 & 0.462 & 0,330 & 0,241 & 0,191 & 0,332 & 0.275 & 0,225 & 0,164 & 0,348 & 0.249 & 0,123 \\
\hline 1995 & 0,455 & 0,322 & 0,235 & 0,191 & 0,336 & 0,274 & 0,228 & 0,179 & 0,347 & 0,247 & 0,135 \\
\hline 1996 & 0,412 & 0,270 & 0,211 & 0,169 & 0,306 & 0,243 & 0,199 & 0,155 & 0,307 & 0,203 & 0,097 \\
\hline 1997 & 0,403 & 0,240 & 0,175 & 0,144 & 0,258 & 0,194 & 0,164 & 0,134 & 0,259 & 0,159 & 0,087 \\
\hline 1998 & 0,407 & 0.213 & 0.157 & 0.120 & 0.229 & 0.162 & 0.145 & 0.112 & 0.234 & 0.156 & 0.088 \\
\hline 1999 & 0,408 & 0,216 & 0,160 & 0,129 & 0,237 & 0,164 & 0,170 & 0,136 & 0,250 & 0,159 & 0,080 \\
\hline 2000 & 0,371 & 0,225 & 0.180 & 0,143 & 0.251 & 0.172 & 0,181 & 0,135 & 0,255 & 0.165 & 0.105 \\
\hline 2001 & 0,319 & 0,201 & 0,169 & 0,135 & 0,246 & 0,159 & 0,171 & 0,135 & 0,257 & 0,145 & 0,119 \\
\hline
\end{tabular}

Tabela 3.24 - Taxa de repetência segundo os censos escolares

\begin{tabular}{|c|c|c|c|c|c|c|c|c|c|c|c|}
\hline & $1^{2}$ série & $2^{a}$ série & $3^{2}$ série & $4^{a}$ série & $5^{a}$ série & $6^{a}$ série & $7^{*}$ série & $8^{4}$ série & $9^{n}$ série & $10^{\circ}$ série & $11^{2}$ série \\
\hline 1981 & 0,296 & 0,207 & 0,169 & 0,134 & 0,227 & 0,199 & 0,170 & 0,123 & 0,143 & 0,095 & 0,046 \\
\hline 1982 & 0.284 & 0,210 & 0,169 & 0,134 & 0,227 & 0,199 & 0,169 & 0,120 & 0,147 & 0,096 & 0,046 \\
\hline 1983 & 0.282 & 0,218 & 0,171 & 0,136 & 0,237 & 0,201 & 0,167 & 0,117 & 0,150 & 0,097 & 0,047 \\
\hline 1984 & 0.223 & 0,207 & 0,163 & 0,132 & 0,238 & 0,199 & 0,197 & 0,150 & 0,163 & 0,097 & 0,048 \\
\hline 1985 & 0,214 & 0,199 & 0,167 & 0,137 & 0,243 & 0,198 & 0,161 & 0,111 & 0,151 & 0,099 & 0,050 \\
\hline 1986 & ก,228 & $n, 203$ & 0,181 & 0,146 & 0,243 & 0,203 & 0,166 & 0,114 & 0,140 & $n, 006$ & $n, 050$ \\
\hline 1987 & 0,223 & 0,198 & 0,174 & 0,138 & 0,238 & 0,194 & 0,161 & 0,112 & 0,142 & 0,096 & 0,050 \\
\hline 1988 & 0.214 & 0,191 & 0,171 & 0,137 & 0,231 & 0,190 & 0.154 & 0,107 & 0,136 & 0,091 & 0.047 \\
\hline 1989 & 0.219 & 0,189 & 0,171 & 0,138 & 0,235 & 0,193 & 0,158 & 0,110 & 0,146 & 0,099 & 0,053 \\
\hline 1990 & 0,229 & 0.184 & 0,169 & 0,135 & 0,235 & 0,194 & 0,159 & 0,110 & 0,152 & 0,107 & 0,059 \\
\hline 1991 & 0,226 & 0,177 & 0,157 & 0,124 & 0,224 & 0,182 & 0,148 & 0,102 & 0,127 & 0,088 & 0,048 \\
\hline 1992 & 0,229 & 0,183 & 0,159 & 0,124 & 0,218 & 0,178 & 0,143 & 0,098 & 0,144 & 0,100 & 0,055 \\
\hline 1993 & 0,237 & 0,213 & 0,157 & 0,122 & 0,218 & 0,175 & 0,142 & 0,099 & 0,146 & 0,102 & 0,057 \\
\hline 1994 & 0,218 & 0,181 & 0,151 & 0,115 & 0,217 & 0,177 & 0,139 & 0,096 & 0,115 & 0,081 & 0,043 \\
\hline 1995 & 0,214 & 0,177 & 0,143 & 0,111 & 0,212 & 0,169 & 0,133 & 0,097 & 0,151 & 0,102 & 0,053 \\
\hline 1996 & 0,207 & 0.164 & 0,151 & 0,095 & 0,181 & 0,141 & 0.107 & 0,077 & 0,231 & 0,154 & 0.081 \\
\hline 1997 & 0,211 & 0.153 & 0,109 & 0.116 & 0,144 & 0,111 & 0,090 & 0,067 & 0,205 & 0,141 & 0,086 \\
\hline 1998 & 0,176 & 0,131 & 0,096 & 0,076 & 0,114 & 0,091 & 0,075 & 0,061 & 0,092 & 0,064 & 0,038 \\
\hline 1999 & 0,163 & 0,131 & 0,094 & 0,084 & 0,115 & 0,095 & 0,078 & 0,067 & 0,097 & 0,068 & 0,041 \\
\hline 2000 & 0,171 & 0,140 & 0,102 & 0,092 & 0,128 & 0,101 & 0,084 & 0,073 & 0,109 & 0,074 & 0,046 \\
\hline 2001 & 0,163 & 0,136 & 0,100 & 0,093 & 0,129 & 0,101 & 0,084 & 0,076 & 0,102 & 0,079 & 0,048 \\
\hline
\end{tabular}


Tabela 3.25 - Taxa de reprovação segundo os censos escolares

\begin{tabular}{|l|l|l|l|l|l|l|l|l|l|l|l|}
\hline & $1^{2}$ série & $2^{2}$ série & $3^{a}$ série & $4^{a}$ série & $5^{a}$ série & $6^{a}$ série & $7^{*}$ série & $8^{a}$ série & $9^{a}$ série & $10^{a}$ série & $1^{2}$ série \\
\hline 1981 & 0,283 & 0,212 & 0,178 & 0,143 & 0,245 & 0,211 & 0,183 & 0,133 & 0,189 & 0,123 & 0,057 \\
\hline 1982 & 0,280 & 0,212 & 0,176 & 0,143 & 0,245 & 0,221 & 0,180 & 0,127 & 0,197 & 0,121 & 0,055 \\
\hline 1983 & 0,285 & 0,216 & 0,177 & 0,145 & 0,254 & 0,234 & 0,175 & 0,120 & 0,204 & 0,120 & 0,055 \\
\hline 1984 & 0,229 & 0,205 & 0,170 & 0,145 & 0,257 & 0,211 & 0,175 & 0,119 & 0,181 & 0,120 & 0,054 \\
\hline 1985 & 0,222 & 0,232 & 0,172 & 0,140 & 0,254 & 0,208 & 0,171 & 0,112 & 0,178 & 0,116 & 0,056 \\
\hline 1986 & 0,234 & 0,253 & 0,192 & 0,156 & 0,259 & 0,217 & 0,189 & 0,125 & 0,184 & 0,134 & 0,063 \\
\hline 1987 & 0,230 & 0,265 & 0,184 & 0,146 & 0,248 & 0,201 & 0,166 & 0,111 & 0,171 & 0,109 & 0,057 \\
\hline 1988 & 0,222 & 0,254 & 0,175 & 0,142 & 0,236 & 0,192 & 0,155 & 0,105 & 0,165 & 0,105 & 0,054 \\
\hline 1989 & 0,210 & 0,246 & 0,177 & 0,139 & 0,228 & 0,190 & 0,150 & 0,102 & 0,157 & 0,109 & 0,058 \\
\hline 1990 & 0,210 & 0,235 & 0,169 & 0,136 & 0,234 & 0,193 & 0,159 & 0,107 & 0,168 & 0,112 & 0,062 \\
\hline 1991 & 0,213 & 0,226 & 0,158 & 0,125 & 0,220 & 0,177 & 0,144 & 0,096 & 0,186 & 0,107 & 0,057 \\
\hline 1992 & 0,200 & 0,219 & 0,154 & 0,119 & 0,207 & 0,171 & 0,134 & 0,088 & 0,195 & 0,098 & 0,051 \\
\hline 1993 & 0,198 & 0,208 & 0,147 & 0,110 & 0,193 & 0,162 & 0,125 & 0,083 & 0,144 & 0,092 & 0,049 \\
\hline 1994 & 0,200 & 0,200 & 0,144 & 0,108 & 0,204 & 0,171 & 0,131 & 0,087 & 0,158 & 0,104 & 0,055 \\
\hline 1995 & 0,190 & 0,191 & 0,132 & 0,100 & 0,191 & 0,155 & 0,121 & 0,082 & 0,142 & 0,090 & 0,047 \\
\hline 1996 & 0,188 & 0,163 & 0,122 & 0,091 & 0,173 & 0,136 & 0,103 & 0,072 & 0,139 & 0,085 & 0,044 \\
\hline 1997 & 0,181 & 0,135 & 0,090 & 0,070 & 0,123 & 0,096 & 0,075 & 0,054 & 0,104 & 0,063 & 0,036 \\
\hline 1998 & 0,162 & 0,120 & 0,081 & 0,063 & 0,094 & 0,076 & 0,061 & 0,050 & 0,088 & 0,056 & 0,033 \\
\hline 1999 & 0,155 & 0,128 & 0,085 & 0,080 & 0,104 & 0,091 & 0,072 & 0,063 & 0,099 & 0,067 & 0,044 \\
\hline 2000 & 0,155 & 0,135 & 0,092 & 0,084 & 0,113 & 0,097 & 0,077 & 0,072 & 0,100 & 0,071 & 0,047 \\
\hline 2001 & 0,158 & 0,136 & 0,095 & 0,090 & 0,121 & 0,098 & 0,079 & 0,077 & 0,103 & 0,076 & 0,050 \\
\hline
\end{tabular}

Tabela 3.26 - Taxa de afastados por abandono segundo os censos escolares

\begin{tabular}{|c|c|c|c|c|c|c|c|c|c|c|c|}
\hline & $1^{2}$ série & $2^{a}$ série & $3^{2}$ série & $4^{4}$ série & $5^{a}$ série & $6^{4}$ série & $7^{*}$ série & $8^{a}$ série & $9^{*}$ série & $10^{2}$ série & $11^{*}$ série \\
\hline 1981 & 0,130 & 0,085 & 0,082 & 0,078 & 0,150 & 0,129 & 0,124 & 0,097 & 0,222 & 0.157 & 0,074 \\
\hline 1982 & 0,162 & 0,106 & 0,104 & 0,098 & 0,184 & 0,140 & 0,145 & 0,124 & 0,236 & 0,180 & 0,108 \\
\hline 1983 & 0,166 & 0,109 & 0,112 & 0,107 & 0,180 & 0,140 & 0,171 & 0,156 & 0,252 & 0,191 & 0,104 \\
\hline 1984 & 0,199 & 0,128 & 0,121 & 0,115 & 0,200 & 0.175 & 0,170 & 0,140 & 0,289 & 0.216 & 0,109 \\
\hline 1985 & 0,187 & 0,121 & 0,121 & 0,126 & 0,192 & 0,168 & 0,157 & 0,134 & 0,281 & 0,213 & 0,093 \\
\hline 1986 & 0,170 & 0,125 & 0,117 & 0,115 & 0,205 & 0,182 & 0,167 & 0,139 & 0,278 & 0,193 & 0,088 \\
\hline 1987 & 0,169 & 0,114 & 0,123 & 0,119 & 0,205 & 0,182 & 0,172 & 0,139 & 0,285 & 0,211 & 0,096 \\
\hline 1988 & 0,190 & 0,123 & 0,139 & 0,130 & 0,214 & 0,182 & 0,175 & 0,144 & 0,296 & 0,219 & 0,100 \\
\hline 1989 & 0,200 & 0,114 & 0,122 & 0,118 & 0,218 & 0,185 & 0,177 & 0,146 & 0,308 & 0,224 & 0,112 \\
\hline 1990 & 0.183 & 0,116 & 0,119 & 0,121 & 0,218 & 0,187 & 0,175 & 0,152 & 0,311 & 0.232 & 0,115 \\
\hline 1991 & 0,172 & 0,125 & 0,120 & 0,118 & 0,210 & 0,181 & 0,174 & 0,146 & 0,284 & 0,198 & 0,095 \\
\hline 1992 & 0.199 & 0,140 & 0,131 & 0,124 & 0,208 & 0,176 & 0,170 & 0,141 & 0,286 & 0,210 & 0,113 \\
\hline 1993 & 0,201 & 0,148 & 0,131 & 0,124 & 0,200 & 0,164 & 0,153 & 0,121 & 0,262 & 0,178 & 0,081 \\
\hline 1994 & 0,179 & 0,130 & 0,115 & 0,105 & 0,165 & 0,138 & 0,129 & 0,095 & 0,248 & 0,183 & 0,088 \\
\hline 1995 & 0,196 & 0,131 & 0,122 & 0,117 & 0,184 & 0,159 & 0,146 & 0,125 & 0,268 & 0,206 & 0,116 \\
\hline 1996 & 0,181 & 0,107 & 0,102 & 0,094 & 0,170 & 0,143 & 0,133 & 0,107 & 0,212 & 0,151 & 0,064 \\
\hline 1997 & 0,153 & 0,105 & 0,096 & 0,090 & 0,159 & 0,134 & 0,119 & 0,095 & 0,198 & 0,141 & 0,075 \\
\hline 1998 & 0,144 & 0,098 & 0,093 & 0,079 & 0,164 & 0,123 & 0,115 & 0,083 & 0,176 & 0,136 & 0,073 \\
\hline 1999 & 0,141 & 0,098 & 0,099 & 0,073 & 0,161 & 0,111 & 0,140 & 0,085 & 0,200 & 0,133 & 0,050 \\
\hline 2000 & 0,148 & 0,101 & 0,111 & 0,079 & 0,166 & 0,113 & 0,156 & 0,073 & 0,224 & 0,154 & 0,084 \\
\hline 2001 & 0,105 & 0,075 & 0,092 & 0,058 & 0,154 & 0,092 & 0,135 & 0,068 & 0,234 & 0,100 & 0,101 \\
\hline
\end{tabular}


Tabela 3.27 - Taxa de promoção corrigida

\begin{tabular}{|l|l|l|l|l|l|l|l|l|l|l|l|}
\hline & $1^{2}$ série & $2^{2}$ série & $3^{2}$ série & $4^{2}$ série & $5^{a}$ série & $6^{a}$ série & $7^{*}$ série & $8^{a}$ série & $9^{*}$ série & $10^{2}$ série & $11^{2}$ série \\
\hline 1981 & 0,400 & 0,652 & 0,690 & 0,679 & 0,550 & 0,607 & 0,654 & 0,653 & 0,542 & 0,689 & 0,869 \\
\hline 1982 & 0,377 & 0,624 & 0,665 & 0,638 & 0,514 & 0,585 & 0,639 & 0,628 & 0,523 & 0,659 & 0,837 \\
\hline 1983 & 0,394 & 0,618 & 0,654 & 0,632 & 0,503 & 0,556 & 0,592 & 0,593 & 0,507 & 0,651 & 0,841 \\
\hline 1984 & 0,416 & 0,607 & 0,651 & 0,614 & 0,478 & 0,547 & 0,606 & 0,611 & 0,481 & 0,628 & 0,837 \\
\hline 1985 & 0,451 & 0,590 & 0,653 & 0,634 & 0,495 & 0,563 & 0,625 & 0,636 & 0,501 & 0,649 & 0,851 \\
\hline 1986 & 0,454 & 0,564 & 0,639 & 0,611 & 0,468 & 0,530 & 0,591 & 0,609 & 0,489 & 0,640 & 0,849 \\
\hline 1987 & 0,469 & 0,566 & 0,645 & 0,633 & 0,490 & 0,561 & 0,625 & 0,657 & 0,508 & 0,653 & 0,847 \\
\hline 1988 & 0,457 & 0,567 & 0,641 & 0,634 & 0,497 & 0,568 & 0,629 & 0,642 & 0,493 & 0,646 & 0,845 \\
\hline 1989 & 0,485 & 0,590 & 0,664 & 0,655 & 0,503 & 0,574 & 0,637 & 0,648 & 0,488 & 0,634 & 0,830 \\
\hline 1990 & 0,512 & 0,601 & 0,671 & 0,652 & 0,497 & 0,568 & 0,627 & 0,627 & 0,471 & 0,624 & 0,823 \\
\hline 1991 & 0,511 & 0,603 & 0,683 & 0,675 & 0,522 & 0,591 & 0,646 & 0,658 & 0,505 & 0,665 & 0,848 \\
\hline 1992 & 0,505 & 0,595 & 0,676 & 0,678 & 0,537 & 0,602 & 0,662 & 0,660 & 0,506 & 0,664 & 0,837 \\
\hline 1993 & 0,498 & 0,606 & 0,685 & 0,688 & 0,562 & 0,628 & 0,695 & 0,717 & 0,560 & 0,707 & 0,870 \\
\hline 1994 & 0,528 & 0,637 & 0,713 & 0,727 & 0,592 & 0,651 & 0,720 & 0,721 & 0,555 & 0,893 & 0,858 \\
\hline 1995 & 0,535 & 0,644 & 0,713 & 0,719 & 0,576 & 0,639 & 0,700 & 0,690 & 0,539 & 0,673 & 0,837 \\
\hline 1996 & 0,578 & 0,704 & 0,755 & 0,755 & 0,615 & 0,675 & 0,735 & 0,751 & 0,615 & 0,752 & 0,892 \\
\hline 1997 & 0,587 & 0,735 & 0,793 & 0,800 & 0,675 & 0,732 & 0,787 & 0,782 & 0,651 & 0,770 & 0,889 \\
\hline 1998 & 0,583 & 0,753 & 0,794 & 0,812 & 0,695 & 0,762 & 0,798 & 0,819 & 0,695 & 0,787 & 0,894 \\
\hline 1999 & 0,582 & 0,743 & 0,785 & 0,802 & 0,690 & 0,743 & 0,773 & 0,771 & 0,653 & 0,783 & 0,906 \\
\hline 2000 & 0,619 & 0,732 & 0,770 & 0,791 & 0,674 & 0,722 & 0,755 & 0,746 & 0,607 & 0,744 & 0,870 \\
\hline 2001 & 0,671 & 0,764 & 0,795 & 0,805 & 0,686 & 0,751 & 0,774 & 0,728 & 0,630 & 0,783 & 0,849 \\
\hline
\end{tabular}

Tabela 3.28 - Taxa de evasão de aprovados corrigida

\begin{tabular}{|l|l|l|l|l|l|l|l|l|l|l|l|}
\hline & $1^{2}$ série & $2^{a}$ série & $3^{a}$ série & $4^{a}$ série & $5^{a}$ série & $6^{a}$ série & $7^{*}$ série & $8^{a}$ série & $9^{a}$ série & $10^{a}$ série & $11^{2}$ série \\
\hline 1981 & 0,010 & 0,051 & 0,051 & 0,100 & 0,054 & 0,054 & 0,040 & 0,117 & 0,047 & 0,031 & 0 \\
\hline 1982 & 0,010 & 0,058 & 0,055 & 0,121 & 0,057 & 0,054 & 0,036 & 0,122 & 0,044 & 0,039 & 0 \\
\hline 1983 & 0,010 & 0,057 & 0,057 & 0,115 & 0,062 & 0,071 & 0,061 & 0,132 & 0,037 & 0,039 & 0 \\
\hline 1984 & 0,010 & 0,059 & 0,058 & 0,126 & 0,065 & 0,067 & 0,049 & 0,131 & 0,049 & 0,036 & 0 \\
\hline 1985 & 0,010 & 0,048 & 0,054 & 0,101 & 0,059 & 0,061 & 0,046 & 0,118 & 0,039 & 0,023 & 0 \\
\hline 1986 & 0,010 & 0,048 & 0,052 & 0,118 & 0,068 & 0,071 & 0,053 & 0,127 & 0,049 & 0,033 & 0 \\
\hline 1987 & 0,010 & 0,045 & 0,048 & 0,102 & 0,057 & 0,056 & 0,037 & 0,094 & 0,036 & 0,027 & 0 \\
\hline 1988 & 0,010 & 0,046 & 0,045 & 0,094 & 0,054 & 0,058 & 0,041 & 0,110 & 0,046 & 0,030 & 0 \\
\hline 1989 & 0,010 & 0,040 & 0,038 & 0,089 & 0,051 & 0,051 & 0,036 & 0,105 & 0,048 & 0,034 & 0 \\
\hline 1990 & 0,005 & 0,037 & 0,041 & 0,092 & 0,051 & 0,051 & 0,040 & 0,114 & 0,050 & 0,032 & 0 \\
\hline 1991 & 0,005 & 0,036 & 0,039 & 0,083 & 0,048 & 0,051 & 0,036 & 0,100 & 0,025 & 0,029 & 0 \\
\hline 1992 & 0,005 & 0,036 & 0,039 & 0,079 & 0,047 & 0,050 & 0,034 & 0,110 & 0,013 & 0,028 & 0 \\
\hline 1993 & 0,005 & 0,028 & 0,037 & 0,078 & 0,044 & 0,045 & 0,027 & 0,080 & 0,034 & 0,022 & 0 \\
\hline 1994 & 0,005 & 0,022 & 0,020 & 0,001 & 0,039 & 0,041 & 0,020 & 0,097 & 0,039 & 0,020 & 0 \\
\hline 1995 & 0,005 & 0,024 & 0,032 & 0,065 & 0,049 & 0,047 & 0,033 & 0,103 & 0,051 & 0,031 & 0 \\
\hline 1996 & 0,005 & 0,016 & 0,021 & 0,061 & 0,043 & 0,046 & 0,029 & 0,070 & 0,034 & 0,012 & 0 \\
\hline 1997 & 0,005 & 0,015 & 0,021 & 0,040 & 0,043 & 0,038 & 0,019 & 0,070 & 0,047 & 0,027 & 0 \\
\hline 1998 & 0,005 & 0,023 & 0,031 & 0,046 & 0,047 & 0,038 & 0,026 & 0,048 & 0,040 & 0,021 & 0 \\
\hline 1999 & 0,005 & 0,031 & 0,032 & 0,046 & 0,046 & 0,056 & 0,015 & 0,081 & 0,047 & 0,016 & 0 \\
\hline 2000 & 0,005 & 0,033 & 0,027 & 0,046 & 0,048 & 0,069 & 0,012 & 0,109 & 0,069 & 0,031 & 0 \\
\hline 2001 & 0,005 & 0,026 & 0,019 & 0,047 & 0,039 & 0,059 & 0,013 & 0,127 & 0,033 & 0,041 & 0 \\
\hline
\end{tabular}


Tabela 3.29 - Taxa de evasão de não-aprovados corrigida

\begin{tabular}{|l|l|l|l|l|l|l|l|l|l|l|l|}
\hline & $1^{2}$ série & $2^{a}$ série & $3^{a}$ série & $4^{a}$ série & $5^{a}$ série & $6^{a}$ série & $7^{*}$ série & $8^{a}$ série & $9^{a}$ série & $10^{a}$ série & $11^{2}$ série \\
\hline 1981 & 0,010 & 0,015 & 0,042 & 0,042 & 0,070 & 0,049 & 0,045 & 0,033 & 0,071 & 0,043 & 0,027 \\
\hline 1982 & 0,010 & 0,015 & 0,048 & 0,045 & 0,081 & 0,053 & 0,045 & 0,030 & 0,075 & 0,041 & 0,034 \\
\hline 1983 & 0,010 & 0,015 & 0,047 & 0,047 & 0,077 & 0,057 & 0,060 & 0,051 & 0,082 & 0,035 & 0,034 \\
\hline 1984 & 0,010 & 0,015 & 0,050 & 0,047 & 0,083 & 0,060 & 0,058 & 0,042 & 0,080 & 0,046 & 0,032 \\
\hline 1985 & 0,010 & 0,015 & 0,042 & 0,045 & 0,067 & 0,055 & 0,052 & 0,040 & 0,071 & 0,038 & 0,020 \\
\hline 1986 & 0,010 & 0,015 & 0,043 & 0,043 & 0,077 & 0,064 & 0,062 & 0,045 & 0,075 & 0,047 & 0,031 \\
\hline 1987 & 0,010 & 0,015 & 0,039 & 0,040 & 0,067 & 0,054 & 0,049 & 0,032 & 0,054 & 0,034 & 0,025 \\
\hline 1988 & 0,010 & 0,015 & 0,040 & 0,037 & 0,061 & 0,052 & 0,051 & 0,035 & 0,063 & 0,045 & 0,028 \\
\hline 1989 & 0,010 & 0,015 & 0,035 & 0,031 & 0,056 & 0,049 & 0,045 & 0,032 & 0,061 & 0,047 & 0,031 \\
\hline 1990 & 0,005 & 0,010 & 0,032 & 0,033 & 0,058 & 0,048 & 0,045 & 0,034 & 0,067 & 0,050 & 0,030 \\
\hline 1991 & 0,005 & 0,010 & 0,030 & 0,031 & 0,052 & 0,045 & 0,045 & 0,032 & 0,059 & 0,025 & 0,027 \\
\hline 1992 & 0,005 & 0,010 & 0,029 & 0,030 & 0,049 & 0,044 & 0,044 & 0,030 & 0,065 & 0,013 & 0,026 \\
\hline 1993 & 0,005 & 0,010 & 0,023 & 0,028 & 0,047 & 0,040 & 0,040 & 0,023 & 0,047 & 0,035 & 0,021 \\
\hline 1994 & 0,005 & 0,010 & 0,018 & 0,022 & 0,037 & 0,034 & 0,035 & 0,017 & 0,058 & 0,038 & 0,019 \\
\hline 1995 & 0,005 & 0,010 & 0,019 & 0,025 & 0,039 & 0,041 & 0,039 & 0,028 & 0,063 & 0,049 & 0,028 \\
\hline 1996 & 0,005 & 0,010 & 0,013 & 0,016 & 0,036 & 0,036 & 0,037 & 0,024 & 0,043 & 0,033 & 0,011 \\
\hline 1997 & 0,005 & 0,010 & 0,011 & 0,016 & 0,024 & 0,036 & 0,031 & 0,015 & 0,043 & 0,044 & 0,024 \\
\hline 1998 & 0,005 & 0,010 & 0,017 & 0,022 & 0,029 & 0,038 & 0,030 & 0,020 & 0,030 & 0,036 & 0,018 \\
\hline 1999 & 0,005 & 0,010 & 0,023 & 0,024 & 0,027 & 0,037 & 0,042 & 0,012 & 0,050 & 0,041 & 0,014 \\
\hline 2000 & 0,005 & 0,010 & 0,023 & 0,020 & 0,028 & 0,038 & 0,052 & 0,009 & 0,069 & 0,060 & 0,025 \\
\hline 2001 & 0,005 & 0,010 & 0,018 & 0,013 & 0,029 & 0,031 & 0,043 & 0,010 & 0,080 & 0,031 & 0,032 \\
\hline
\end{tabular}

Tabela 3.30 - Taxa de evasão total corrigida

\begin{tabular}{|l|l|l|l|l|l|l|l|l|l|l|l|}
\hline & $1^{2}$ série & $2^{2}$ série & $3^{a}$ série & $4^{a}$ série & $5^{a}$ série & $6^{a}$ série & $7^{*}$ série & $8^{a}$ série & $9^{a}$ série & $10^{a}$ série & $11^{*}$ série \\
\hline 1981 & 0,020 & 0,066 & 0,093 & 0,142 & 0,124 & 0,103 & 0,084 & 0,150 & 0,118 & 0,074 & 0,027 \\
\hline 1982 & 0,020 & 0,073 & 0,102 & 0,165 & 0,138 & 0,106 & 0,082 & 0,152 & 0,119 & 0,080 & 0,034 \\
\hline 1983 & 0,020 & 0,072 & 0,105 & 0,162 & 0,140 & 0,128 & 0,121 & 0,183 & 0,120 & 0,073 & 0,034 \\
\hline 1984 & 0,020 & 0,074 & 0,108 & 0,173 & 0,148 & 0,127 & 0,107 & 0,173 & 0,129 & 0,082 & 0,032 \\
\hline 1985 & 0,020 & 0,063 & 0,097 & 0,145 & 0,125 & 0,116 & 0,098 & 0,158 & 0,110 & 0,061 & 0,020 \\
\hline 1986 & 0,030 & $n, 063$ & $0, n 94$ & 0,161 & 0,145 & 0,135 & 0,115 & 0,172 & 0,124 & 0,081 & 0,031 \\
\hline 1987 & 0,020 & 0,060 & 0,087 & 0,142 & 0,124 & 0,110 & 0,086 & 0,126 & 0,090 & 0,061 & 0,025 \\
\hline 1988 & 0,020 & 0,061 & 0,086 & 0,131 & 0,115 & 0,109 & 0,091 & 0,145 & 0,109 & 0,075 & 0,028 \\
\hline 1989 & 0,020 & 0,055 & 0,072 & 0,119 & 0,108 & 0,100 & 0,082 & 0,137 & 0,109 & 0,080 & 0,031 \\
\hline 1990 & 0,010 & 0,047 & 0,073 & 0,124 & 0,109 & 0,100 & 0,085 & 0,148 & 0,117 & 0,083 & 0,030 \\
\hline 1991 & 0,010 & 0,046 & 0,069 & 0,114 & 0,100 & 0,096 & 0,081 & 0,132 & 0,084 & 0,055 & 0,027 \\
\hline 1992 & 0,010 & 0,046 & 0,068 & 0,109 & 0,096 & 0,094 & 0,078 & 0,140 & 0,077 & 0,041 & 0,026 \\
\hline 1993 & 0,010 & 0,038 & 0,060 & 0,106 & 0,092 & 0,085 & 0,066 & 0,103 & 0,081 & 0,057 & 0,021 \\
\hline 1994 & 0,010 & 0,032 & 0,046 & 0,082 & 0,076 & 0,074 & 0,055 & 0,114 & 0,097 & 0,059 & 0,019 \\
\hline 1995 & 0,010 & 0,034 & 0,052 & 0,090 & 0,088 & 0,087 & 0,072 & 0,131 & 0,114 & 0,080 & 0,028 \\
\hline 1996 & 0,010 & 0,026 & 0,034 & 0,077 & 0,079 & 0,082 & 0,066 & 0,094 & 0,078 & 0,046 & 0,011 \\
\hline 1997 & 0,010 & 0,025 & 0,032 & 0,056 & 0,067 & 0,074 & 0,049 & 0,084 & 0,090 & 0,071 & 0,024 \\
\hline 1998 & 0,010 & 0,033 & 0,048 & 0,068 & 0,076 & 0,076 & 0,056 & 0,069 & 0,071 & 0,057 & 0,018 \\
\hline 1999 & 0,010 & 0,041 & 0,055 & 0,069 & 0,073 & 0,093 & 0,057 & 0,093 & 0,097 & 0,058 & 0,014 \\
\hline 2000 & 0,010 & 0,043 & 0,051 & 0,066 & 0,076 & 0,107 & 0,064 & 0,118 & 0,138 & 0,091 & 0,025 \\
\hline 2001 & 0,010 & 0,036 & 0,036 & 0,060 & 0,067 & 0,090 & 0,056 & 0,137 & 0,113 & 0,072 & 0,032 \\
\hline
\end{tabular}


Tabela 3.31 - Taxa de evasão total sem correção

\begin{tabular}{|l|l|l|l|l|l|l|l|l|l|l|l|}
\hline & $1^{a}$ série & $2^{a}$ série & $3^{a}$ série & $4^{a}$ série & $5^{a}$ série & $6^{a}$ série & $7^{2}$ série & $8^{a}$ série & $9^{a}$ série & $10^{a}$ série & $11^{a}$ série \\
\hline 1981 & 0,255 & 0,091 & 0,093 & 0,048 & 0,139 & 0,102 & 0,100 & $-0,086$ & 0,191 & 0,160 & 0,085 \\
\hline 1982 & 0,281 & 0,103 & 0,103 & 0,065 & 0,163 & 0,111 & 0,096 & $-0,070$ & 0,191 & 0,168 & 0,117 \\
\hline 1983 & 0,266 & 0,096 & 0,106 & 0,068 & 0,160 & 0,130 & 0,139 & $-0,038$ & 0,194 & 0,181 & 0,112 \\
\hline 1984 & 0,290 & 0,113 & 0,110 & 0,072 & 0,176 & 0,167 & 0,130 & $-0,102$ & 0,197 & 0,202 & 0,115 \\
\hline 1985 & 0,227 & 0,137 & 0,100 & 0,045 & 0,158 & 0,132 & 0,124 & $-0,107$ & 0,195 & 0,180 & 0,100 \\
\hline 1986 & 0,187 & 0,157 & 0,103 & 0,052 & 0,180 & 0,152 & 0,145 & $-0,087$ & 0,215 & 0,202 & 0,102 \\
\hline 1987 & 0,167 & 0,154 & 0,098 & 0,034 & 0,161 & 0,131 & 0,116 & $-0,170$ & 0,196 & 0,183 & 0,103 \\
\hline 1988 & 0,187 & 0,153 & 0,096 & 0,019 & 0,164 & 0,129 & 0,120 & $-0,154$ & 0,220 & 0,193 & 0,108 \\
\hline 1989 & 0,163 & 0,138 & 0,082 & $-0,003$ & 0,151 & 0,123 & 0,108 & $-0,152$ & 0,219 & 0,191 & 0,117 \\
\hline 1990 & 0,118 & 0,134 & 0,076 & $-0,002$ & 0,153 & 0,123 & 0,110 & $-0,131$ & 0,234 & 0,194 & 0,118 \\
\hline 1991 & 0,109 & 0,137 & 0,075 & $-0,010$ & 0,144 & 0,115 & 0,107 & $-0,180$ & 0,222 & 0,179 & 0,105 \\
\hline 1992 & 0,109 & 0,131 & 0,078 & $-0,010$ & 0,137 & 0,114 & 0,100 & $-0,170$ & 0,202 & 0,166 & 0,108 \\
\hline 1993 & 0,140 & 0,089 & 0,072 & 0,001 & 0,120 & 0,105 & 0,082 & $-0,160$ & 0,184 & 0,141 & 0,073 \\
\hline 1994 & 0,124 & 0,095 & 0,057 & $-0,019$ & 0,097 & 0,026 & 0,071 & $-0,177$ & 0,194 & 0,156 & 0,100 \\
\hline 1995 & 0,121 & 0,090 & 0,061 & $-0,017$ & 0,110 & 0,098 & 0,085 & $-0,097$ & 0,189 & 0,152 & 0,110 \\
\hline 1996 & 0,115 & 0,068 & 0,017 & $-0,039$ & 0,105 & 0,089 & 0,077 & $-0,008$ & 0,098 & 0,069 & 0,028 \\
\hline 1997 & 0,123 & 0,037 & 0,061 & $-0,090$ & 0,096 & 0,077 & 0,048 & 0,010 & 0,112 & 0,075 & 0,025 \\
\hline 1998 & 0,169 & 0,044 & 0,055 & $-0,048$ & 0,116 & 0,071 & 0,068 & $-0,126$ & 0,122 & 0,095 & 0,069 \\
\hline 1999 & 0,176 & 0,055 & 0,068 & $-0,060$ & 0,124 & 0,064 & 0,071 & $-0,091$ & 0,162 & 0,104 & 0,053 \\
\hline 2000 & 0,126 & 0,042 & 0,071 & $-0,055$ & 0,125 & 0,075 & 0,078 & $-0,054$ & 0,198 & 0,120 & 0,084 \\
\hline 2001 & 0,102 & 0,022 & 0,057 & $-0,059$ & 0,123 & 0,053 & 0,062 & $-0,048$ & 0,204 & 0,059 & 0,103 \\
\hline
\end{tabular}

Tabela 3.32 - Taxa de participação

\begin{tabular}{|c|c|c|c|c|c|c|c|c|c|c|c|c|}
\hline & $1^{*}$ sèrie & $2^{*}$ série & $3^{3}$ série & $4^{a}$ série & $5^{n}$ série & $6^{4}$ série & $7 "$ série & $g^{g}$ série & $9^{x}$ sèrie & $10^{4}$ série & $11^{1 "}$ série & $12^{*}$ série \\
\hline 1981 & 0,897 & 0,854 & 0,799 & 0,719 & 0,546 & 0,476 & 0,422 & 0,367 & 0,273 & 0,243 & 0,212 & 0,099 \\
\hline 1982 & 0,897 & 0,855 & 0,798 & 0,722 & 0,547 & 0,479 & 0,425 & 0,368 & 0,275 & 0,243 & 0,212 & 0,098 \\
\hline 1983 & 0,920 & 0,864 & 0,810 & 0,735 & 0,572 & 0,491 & 0,438 & 0,384 & 0,286 & 0,255 & 0,225 & 0,104 \\
\hline 1984 & 0,925 & 0,866 & 0,813 & 0,740 & 0,577 & 0,502 & 0,446 & 0,394 & 0,291 & 0,259 & 0.230 & 0,107 \\
\hline 1985 & 0,926 & 0,869 & 0,817 & 0,746 & 0,589 & 0,510 & 0,457 & 0,405 & 0,299 & 0,269 & 0,236 & 0,110 \\
\hline 1986 & 0,930 & 0,871 & 0,819 & 0,752 & 0,605 & 0,523 & 0,463 & 0,409 & 0.303 & 0,274 & 0,245 & 0,118 \\
\hline 1987 & 0,933 & 0,878 & 0,822 & 0,752 & 0,608 & 0,522 & 0,465 & 0,411 & 0,308 & 0,282 & 0,254 & 0,122 \\
\hline 1988 & 0,935 & 0,882 & 0.833 & 0,764 & 0,615 & 0,534 & 0,482 & 0,430 & 0.325 & 0,295 & 0,263 & 0,127 \\
\hline 1989 & 0,938 & 0,890 & 0,847 & 0,780 & 0,630 & 0,536 & 0,485 & 0,438 & 0,331 & 0,305 & 0,277 & 0,121 \\
\hline 1990 & 0,939 & 0,891 & 0.840 & 0,777 & 0,638 & 0,548 & 0,489 & 0,438 & 0.336 & 0,311 & 0,280 & 0,124 \\
\hline 1992 & 0,954 & 0,889 & 0,833 & 0,758 & 0,629 & 0,527 & 0,461 & 0,410 & 0,307 & 0,285 & 0,261 & 0,115 \\
\hline 1993 & 0,964 & 0,896 & 0,840 & 0,774 & 0,647 & 0,547 & 0,477 & 0,423 & 0,323 & 0,300 & 0.271 & 0,110 \\
\hline 1995 & 0,969 & 0,910 & 0,859 & 0,790 & 0,681 & 0,582 & 0,509 & 0,443 & 0,347 & 0,303 & 0,270 & 0,114 \\
\hline 1996 & 0,971 & 0,917 & 0.869 & 0,808 & 0,715 & 0,615 & 0,546 & 0,475 & 0,373 & 0,328 & 0,283 & 0,115 \\
\hline 1997 & 0,978 & 0,927 & 0,892 & 0,825 & 0,735 & 0,630 & $0,55 B$ & 0,487 & 0,391 & 0,337 & 0,293 & 0,119 \\
\hline 1998 & 0,982 & 0,939 & 0,891 & 0,836 & 0,755 & 0,671 & 0,598 & 0,532 & 0,435 & 0,376 & 0,319 & 0,118 \\
\hline 1999 & 0,984 & 0,948 & 0,912 & 0,861 & 0,790 & 0,699 & 0,633 & 0,565 & 0,468 & 0,412 & 0,348 & 0,117 \\
\hline 2001 & 0,986 & 0,961 & 0,930 & 0,886 & 0,819 & 0,745 & 0,681 & 0,618 & 0,528 & 0,474 & 0,411 & 0,131 \\
\hline
\end{tabular}


Tabela 3.33 - Taxa de conclusão

\begin{tabular}{|c|c|c|c|c|c|c|c|c|c|c|c|c|}
\hline & $1^{*}$ série & $2^{n}$ série & $3^{3}$ serie & 4" série & $5^{\text {"l sefie }}$ & $6^{a}$ serie & $7^{a}$ série & $g^{\mathrm{a}}$ série & $9^{2}$ série & $10^{\circ}$ série & $11^{\text {t }}$ série & $12^{a}$ série \\
\hline 1980 & 0,881 & 0,849 & 0,792 & 0,709 & 0,529 & 0,461 & 0,409 & 0,353 & 0,259 & 0,232 & 0.204 & 0,094 \\
\hline 1981 & 0,885 & 0,853 & 0,796 & 0,716 & 0,537 & 0,471 & 0,414 & 0,357 & 0,263 & 0,231 & 0.206 & 0,094 \\
\hline 1982 & 0,894 & 0,862 & 0,807 & 0,728 & 0,557 & 0,482 & 0,429 & 0,372 & 0,275 & 0,246 & 0.220 & 0,100 \\
\hline 1983 & 0,893 & 0,862 & 0,809 & 0,732 & 0,568 & 0,493 & 0,440 & 0,385 & 0,280 & 0.252 & 0.226 & 0,105 \\
\hline 1984 & 0,893 & 0,866 & 0,813 & 0,740 & 0,582 & 0,504 & 0,449 & 0,396 & 0,288 & 0,262 & 0,230 & 0,107 \\
\hline 1985 & 0,896 & 0,865 & 0,816 & 0,747 & 0,597 & 0,515 & 0,456 & 0.401 & 0,292 & 0,270 & 0.242 & 0,116 \\
\hline 1986 & 0,903 & 0,869 & 0,817 & 0,747 & 0,601 & 0,517 & 0,460 & 0.403 & 0,303 & 0,279 & 0.250 & 0,119 \\
\hline 1997 & 0.905 & 0.876 & 0.827 & 0,760 & 0,611 & 0,531 & 0,477 & 0.424 & 0,318 & $0,28 B$ & 0.259 & 0,124 \\
\hline 1988 & 0,913 & 0,887 & 0,843 & 0,774 & 0,623 & 0,534 & 0,483 & 0,435 & 0,328 & 0,301 & 0.270 & 0,119 \\
\hline 1989 & 0,912 & 0,882 & 0.836 & 0,773 & 0,631 & 0,542 & 0,486 & 0,436 & 0,332 & 0,308 & 0.276 & 0,122 \\
\hline 1991 & 0,907 & 0,871 & 0,821 & 0,750 & 0,619 & 0,517 & 0,458 & 0,408 & 0,303 & 0,283 & 0.258 & 0,111 \\
\hline 1992 & 0,811 & 0,878 & 0,837 & 0,769 & 0,636 & 0.535 & 0,474 & 0,421 & 0,320 & 0,296 & 0.267 & 0,107 \\
\hline 1994 & 0,922 & 0,888 & 0,847 & 0,784 & 0,664 & 0,567 & 0,498 & 0,434 & 0,326 & 0,295 & 0,266 & 0,111 \\
\hline 1995 & 0,927 & 0,892 & 0.851 & 0,792 & 0,686 & 0,593 & 0,523 & 0.454 & 0,348 & 0,310 & 0.281 & 0,111 \\
\hline 1996 & 0,935 & 0,903 & 0,859 & 0,801 & 0,695 & 0,599 & 0,526 & 0,458 & 0,360 & 0,318 & 0,283 & 0,115 \\
\hline 1997 & 0,944 & 0,908 & 0.864 & 0,813 & 0,726 & 0.641 & 0,571 & 0.497 & 0,396 & 0,344 & 0,301 & 0,114 \\
\hline 1998 & 0,952 & 0,924 & 0,883 & 0,833 & 0,750 & 0,669 & 0,604 & 0,532 & 0,432 & 0,371 & 0,320 & 0,110 \\
\hline 2000 & 0,964 & 0,936 & 0,898 & 0,847 & 0,783 & 0,713 & 0,656 & 0,592 & 0,495 & 0,438 & 0,375 & 0,118 \\
\hline
\end{tabular}




\section{Anexo 4}

\section{FICHA DE MATRICULA}

BLOCO 1 - IDENTIFICAÇÃO E CADASTRO

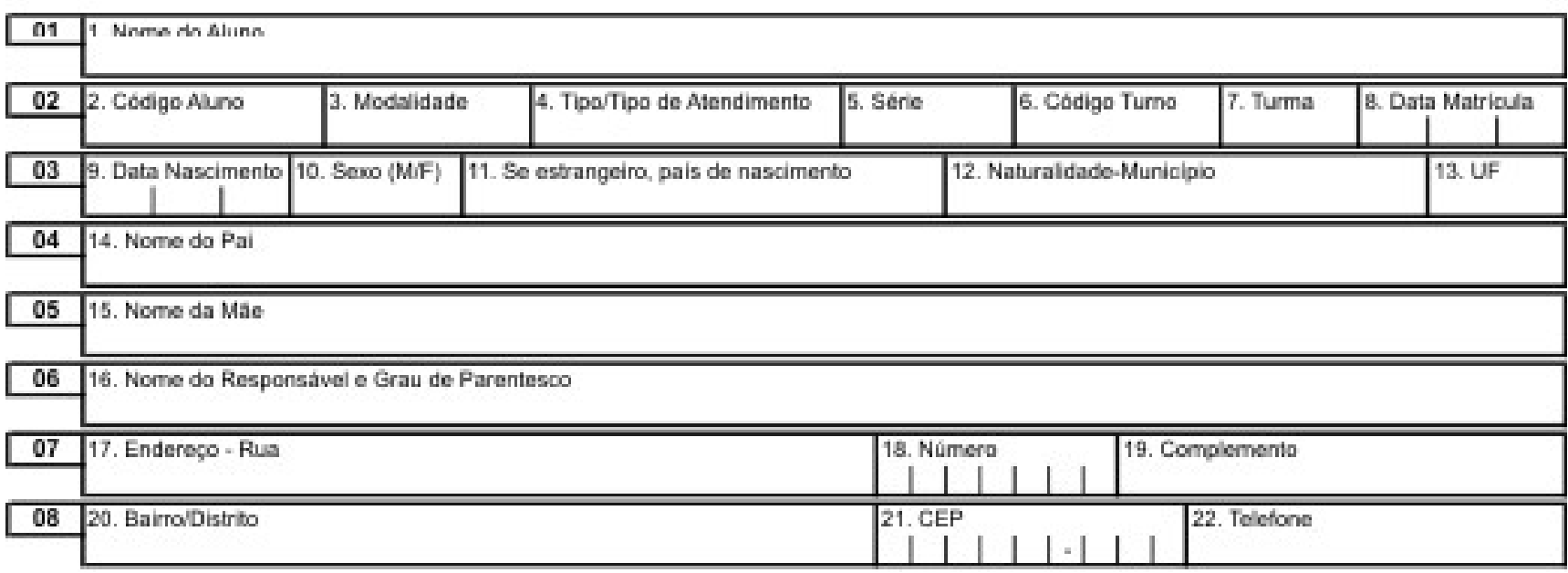

\section{BLOCO 2 - CARACTERIZAÇĀO}

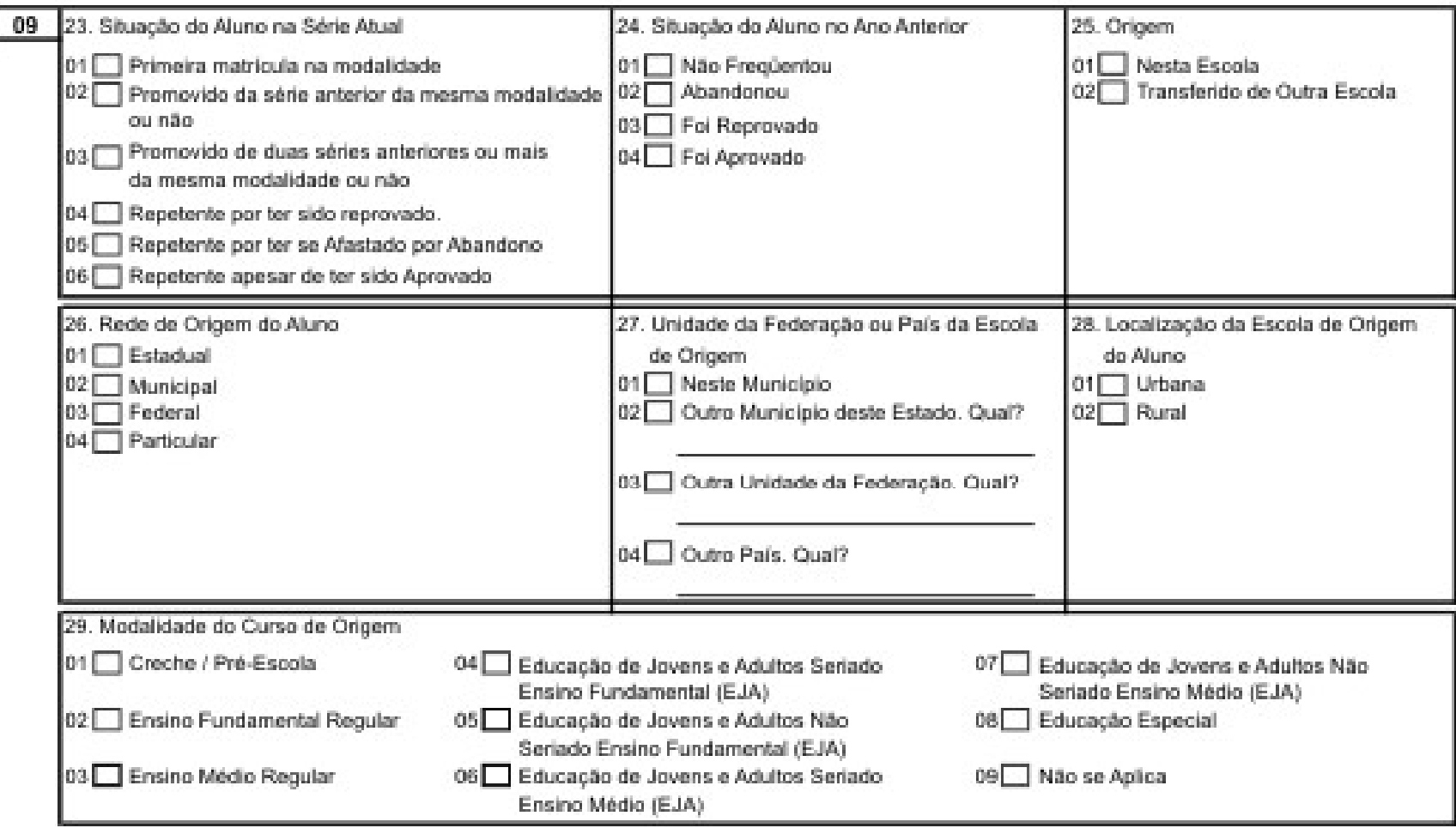

BLOCO 3 - ASSINATURAS

\begin{tabular}{|c|l|l|l|l|}
\hline \begin{tabular}{|l|l|} 
30. Data \\
L
\end{tabular} & 31. Socretario & 3iretor & Pa ou MSe ou Responsaivel \\
\hline
\end{tabular}


Creche: Modalidade da Educaçăo Infantil direcionada a crianças de até 3 anos de idade (inclusive).

Pré-Escola: Modalidade da Educaçâo Infantil direcionada a crianças de 4 a 6 anos de idade (inclusive), geralmente dividida em 3 periodos (anos).

Classe de Alfabetização: Hoje em dia considerada parte do Ensino Fundamental Regular, direcionada a crianças de 6 anos. Preencher como "série O" no Ensino Fundamental Regular.

Ciclo e Nāo Seriado: Formas de organização que agrupam algumas sẻries. Preencher conforme instruçōes em "Série".

Atenção: Apenas para efeilo de cálculo do fluxo de alunos no Sistema de Ensino, estabelecer urna correspondéncia entre os/as módulos/etapas com as séries do Sistema Regular de Ensino.

\section{BLOCO 1 - Identificação e Cadastro}

1. Nome de Alune: Preencher o nome completo do aluno.

2. Cédige de Alune: Preencher com o nùmero de registro do aluno na escola ou conforme instruçōes da Secretaría de Educaçăo correspondente.

3. Modalidade: Preencher com o código do curso no qual o aluno está sendo matriculado.

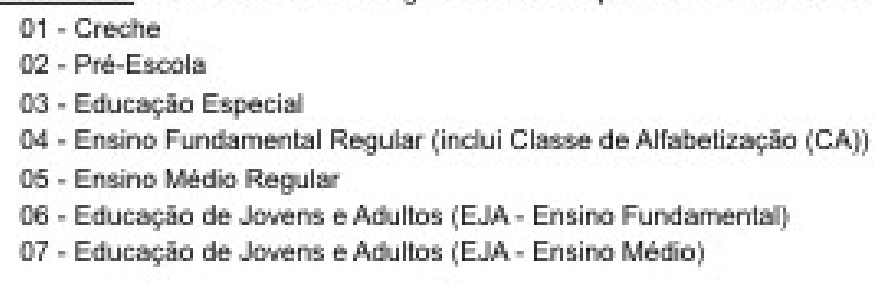

4. Tipo/Tipe de Atendimente: Preencher com o ébdigo do Tipo de Atendimento na Educação Especial (Exemplo: DV para deficiente visual), Indicar se o aluno está matriculado em um sistema de ciclo ou curso nāo seriado. (Exemplo: CL para ciclo. NS para năo seriado. CA para classe de aceleração.)

5. Série: Nümero da série em que o aluno está sendo matriculado. 


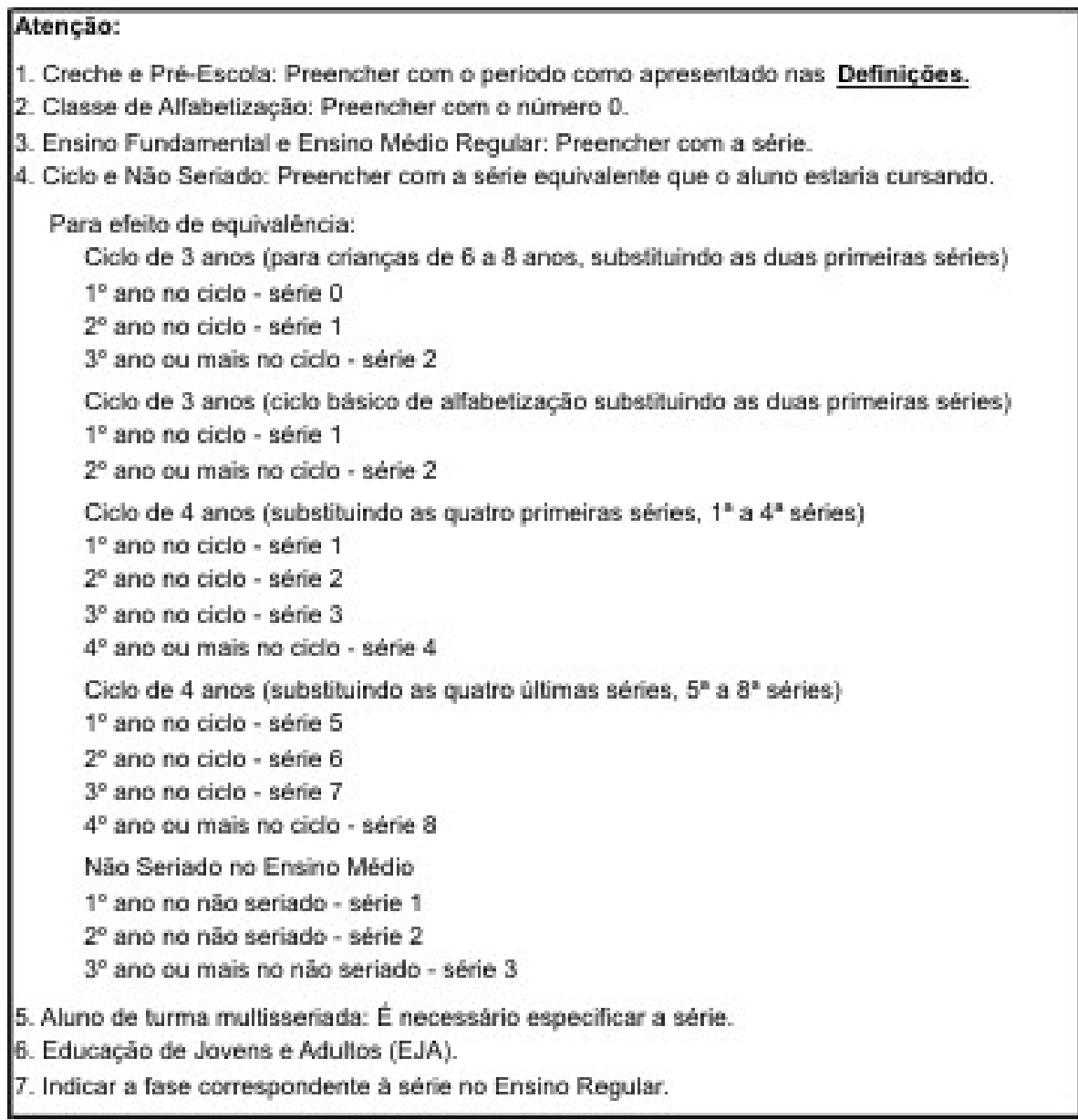

\section{Código Turno:}

1 Manhå 2 Intermediária/Manhă 3 Tarde $\quad 4$ Intermediária/Tarde $\quad 5$ Noite 6 Integral

$\underline{\text { 7. Turma: }}$ Preencher com a identificação da turma na qual o aluno foi inserido.

8. Data Matricula: Data de preenchimento da ficha.

9. Data de Nascimento: Preencher com a data de nascimento do aluno, sendo dois algarismos para o dia, o mês e o ano.

10. Sexo: Informar o sexo do aluno, utilizando o nùmero 1 para o masculino e o nủmero 2 para feminino, embora no formulário possam aparecer as designaçóes $\mathbf{M}$ e $\mathbf{F}$.

11. Se Estrangeiro: Preencher com o nome do pais de nascimento.

12. Naturalidade: Preencher com o nome do municipio em que o aluno nasceu.

13. UF: Informar a sigla da unidade da federação correspondente ao municipio em que o aluno nasceu.

14. Nome do Pai: Preencher com o nome completo.

15. Nome da Mäe: Preencher com o nome completo.

16. Nome de Responstável e Grau de Parentesce: Preencher com o nome completo do responsável, caso nảo seja o pai ou a mãe, e o grau de parentesco.

17. Endereço-Rua: Preencher com o nome da rua (avenida, praça, estrada, etc.) da residéncia do aluno.

18. Nùmero-Rua: Preencher com o número (KM, etc.) que identifica a residéncia do aluno na rua. 
19. Complemento - Rua: Preencher com a identificaçăo complementar da residéncia do aluno ( $\mathrm{n}^{\circ}$ do apartamenlo, bloco, fundos, etc.)

20. Bairro/Distrito: Preencher com o nome do bairro, distrito ou localidade da residéneia do aluno.

21. CEP: Preencher com o oito algarismo o código de endereçamento postal da residéncia do aluno.

22. Telefone: Preencher com o número do telefone da residência do aluno, se houver; ou do trabalho de um dos pais ou responsável.

BLOCO 2 - Caracterização

23. Situaçảo do Aluno na Série Atual:

01 - Primeira malricula na modalidade: Para o aluno que ingressar pela $1^{\mathrm{A}}$ vez na vida no curso, independente da série.

\begin{tabular}{|c|c|}
\hline \multicolumn{2}{|c|}{$\begin{array}{l}\text { Matricula no inicio deste ano: } 1^{a} \text { série do Ensino Médio. Aluno nunca ingressou nesta série. } \\
\text { Preencher como } 1^{*} \text { matricula no curso }\end{array}$} \\
\hline Caso 1: & $\begin{array}{l}\text { Alune freqūentou a escola no ano anterior. Última série freqüentada: ga" série do } \\
\text { Ensino Fundarnental. Preencher item 24-04 (foi aprovado) e item 29-04 (Ensine } \\
\text { Fundamental Regular) }\end{array}$ \\
\hline Caso 2: & $\begin{array}{l}\text { Aluno não freqüentou a escola no ano anterior. Preencher item 24-01 (não } \\
\text { freqüentou) e item 29-04 (Ensino Fundamental Regular) }\end{array}$ \\
\hline
\end{tabular}

02 - Promovido da série anterior da mesma modalidade ou não: Para o aluno que foi aprovado na série anterior do mesmo curso ou periodo/série anterior do curso equivalente (exemplo: ensino fundamental e regular e Supletivo de $1^{*}$ grau) e que não tenha se matriculado anteriormente na série atual, nesta ou em outra escola.

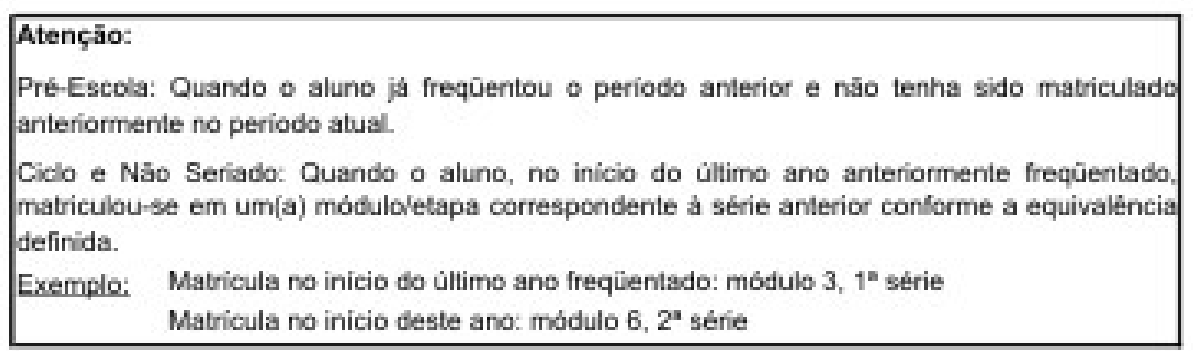

03 - Promovido de duas séries anteriores ou mais da mesma modalidade ou năo: Caso de alunos provenientes de classes de aceleração.

04 - Repetente por ter sido regrowado: Para o aluno que volta a freqüentar a mesma série em que esteve matriculado anteriormente, nesta ou em outra escola, por nảo ter tido a freqüéncia ou o aproveitamento necessário à aprowaçăo.

05 - Repetente por ter se afastado por abandono: Para o aluno que volta a frequientar a mesma série em que esteve matriculado anteriormente, nesta ou em outra escola, por ter deixado de freqüentíla, tendo sua matricula cancelada.

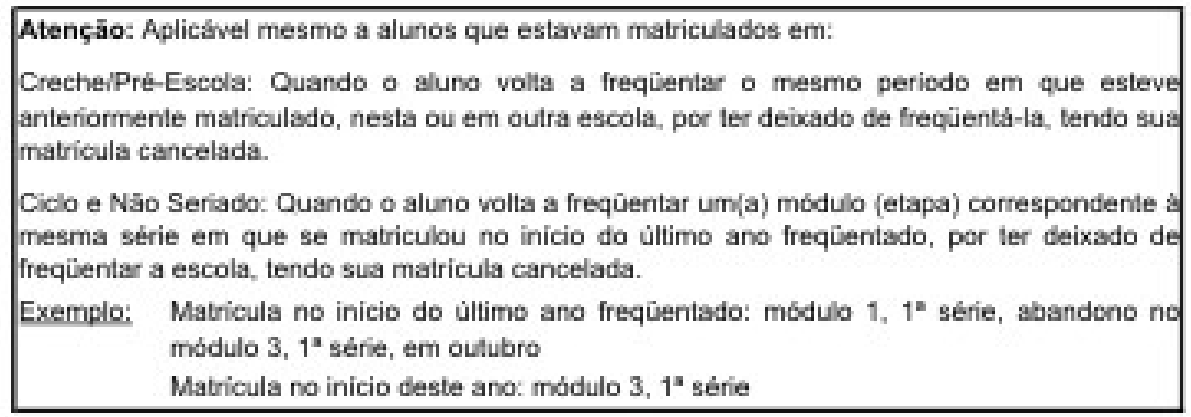


06 - Repetente apesar de ter sido agrovado: Para o aluno que volta a freqũentar a mesma série em que esteve matriculado anteriormente, nesta ou em outra escola, apesar de ter sido aprovado nesta série.

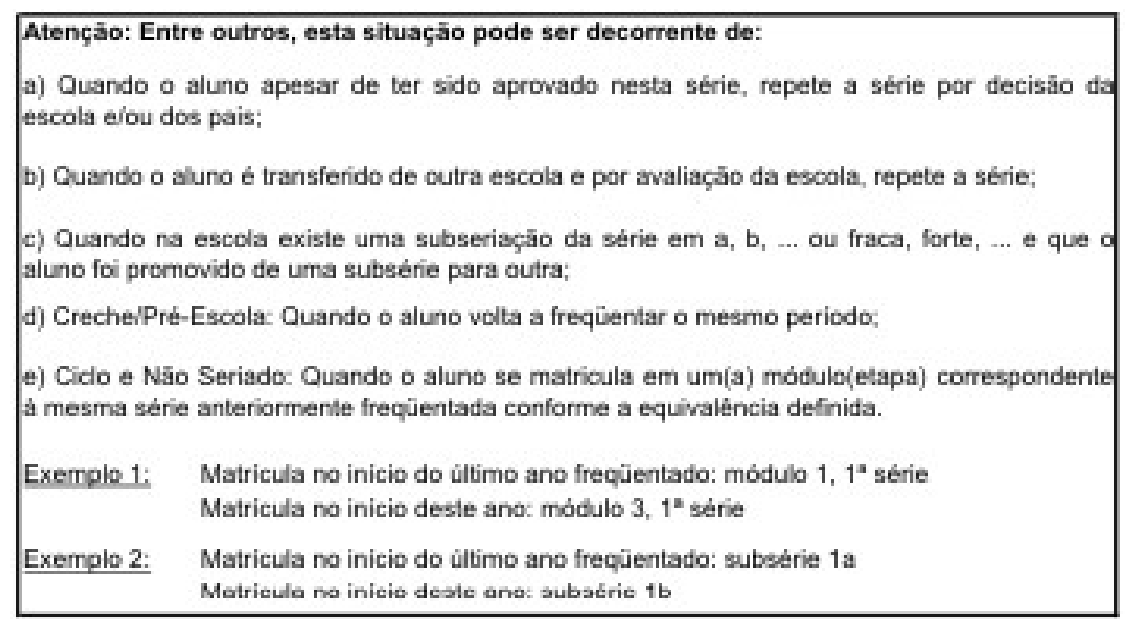

\section{Situação do Aluno no Ano Anterior:}

01 - Não freqüentou: Para o aluno que no ano anterior não freqüentou a escola.

02 - Abandonou: Para o aluno que no ano anterior deixou de frequeentar a escola a escola tendo sua matricula cancelada.

03 - Foi reprovado: Para o aluno que no ano anterior, nāo teve a frequència ou o aproveitamento necessário à aprovação na série que frequientou.

04 - Foi aprovado: Para o aluno que no ano anterior, teve a freqüência e o aproveitamento necessário à aprovação na série que frequêtitou.

\section{Origem:}

01- Nesta escola: Assinalar se a última matricula do aluno foi nesta escola.

02 - Iransferido de cutra escola: Assinalar se a ùltima matricula do aluno foi em outra escola.

26. Rede de Origem do Aluno: Assinalar a dependência adiministrativa da escola de crigem.

$$
\begin{aligned}
& 01 \text { - Estadual } \\
& 02 \text { - Municipal } \\
& 03 \text { - Eederal } \\
& 04 \text { - Particular }
\end{aligned}
$$

\section{Unidade da Federação ou Pais da Escola de Origem:}

\section{1 - Neste municipio}

02. Qutro municipio deste estado. Qual? Assinalar se a escola de origem for de cutro municipio deste estado, indicando o nome do municipio.

03 - Qutra unidade da federaçảo. Qual? Assinalar se a escola de origem for de outro estado da federação, indicando o nome e a sigla do estado.

04 - Outro pais. Qual? Assinalar se a escola de origem for de cutro pais, indicando o nome do pais.

28. Lecalizaçio da Escola de Origem de Alune: Assinalar a lacalizaçâo da escola de origem do aluno.

$$
01 \text { - Urbana }
$$

29. Modalidade do Curso de Origem do Aluno: Assinalar o útimo curso freqūentado pelo aluno. 01 - Creche/Pré-Escola

02 - Ensino Fundamental Regular

03 - Ensine Nedolo Regular

04 - Educaçăo de Jovens e Adullos Seriado Ensino Fundamental (E.JA)

05 - Educação de Jovens e Adultos Não Seriado Ensino Fundamental (EJA)

06 - Educaçāo de Jovens e Adulltos Seriado Ensino Médio (EJA)

07 - Educaçāo de Jovens e Adultos Não Seriado Ensino Médio (EJA)

08 - Ensine Especial

09 - Não se aplica: Assinalar quando o aluno nunca freqūentou a escola. 


\section{BLOCO 3-Assinaturas}

30. Data: Informar a data do preenchimento da ficha

31. Secretário: Assinatura do secretảio da escola

32. Diretor: Assinatura do direlor da escola

33. Pai ou Mãe ou Responsável: Assinatura da pessos que efetuou a matricula do aluno. 